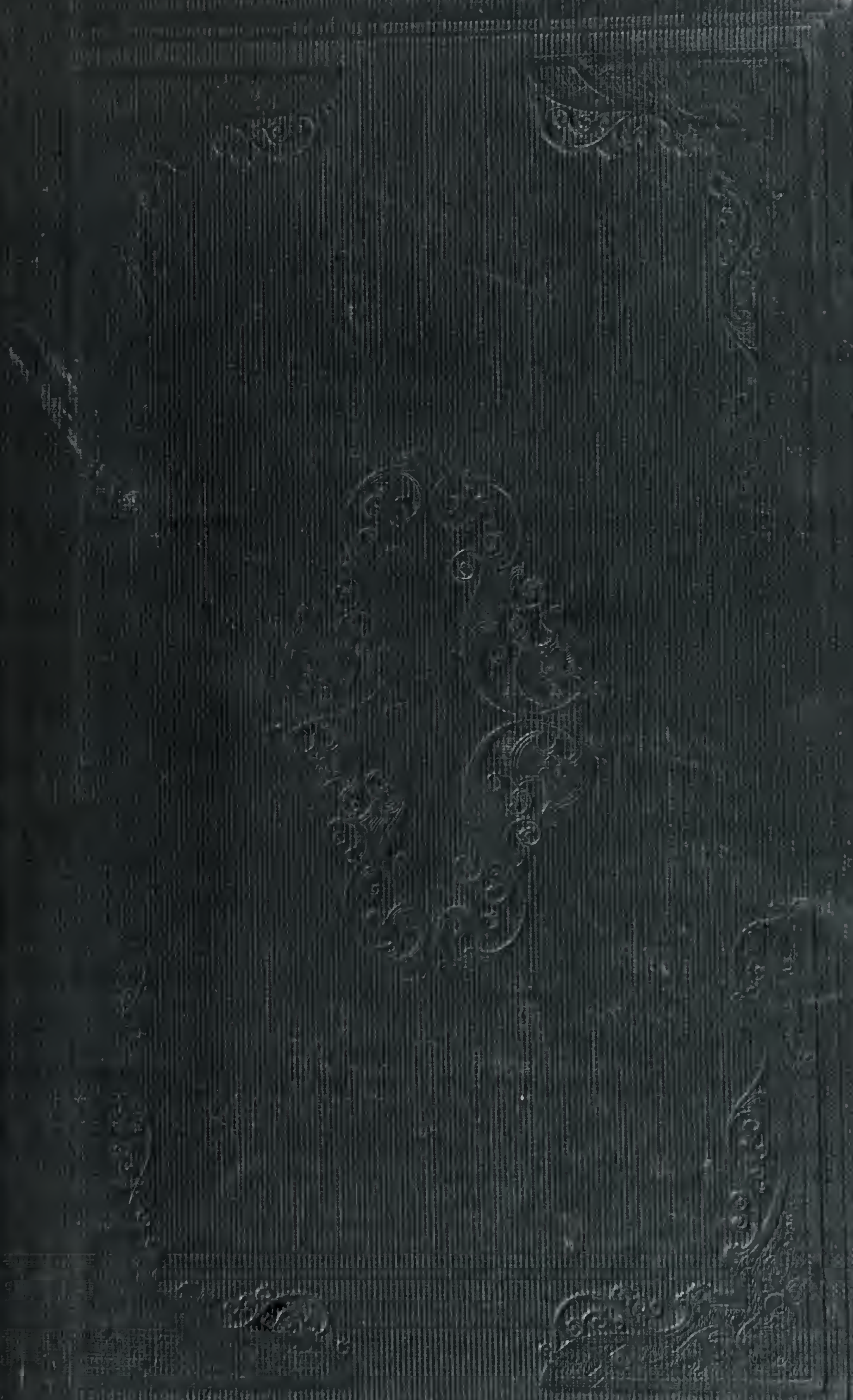

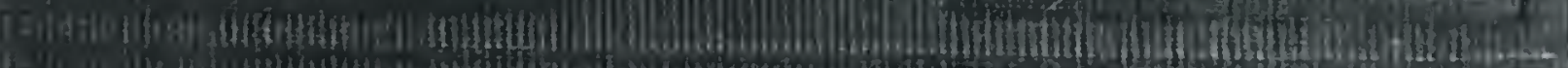

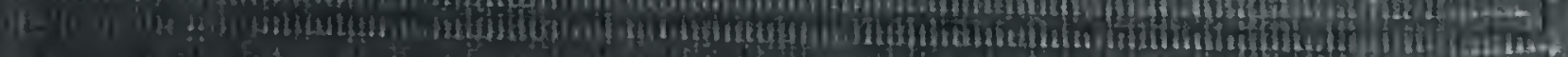

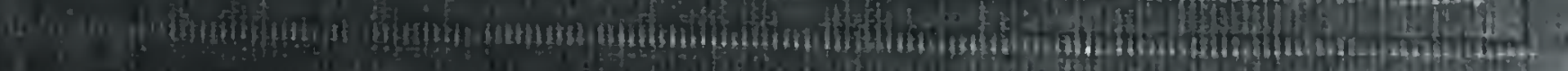


QE905

.P3

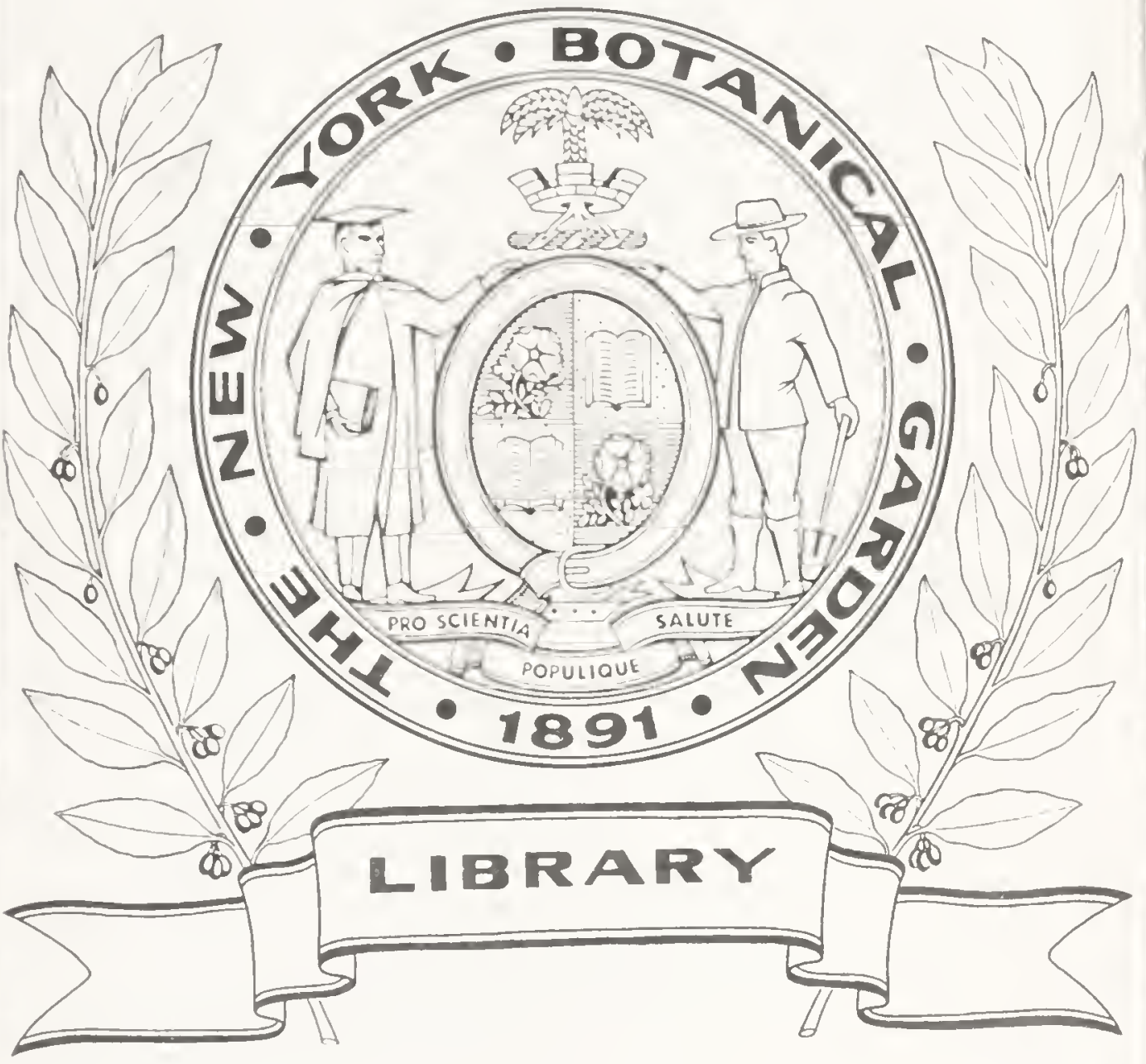


-

-

ij 

CHAPTERS ON FOSSIL BOTANY. 



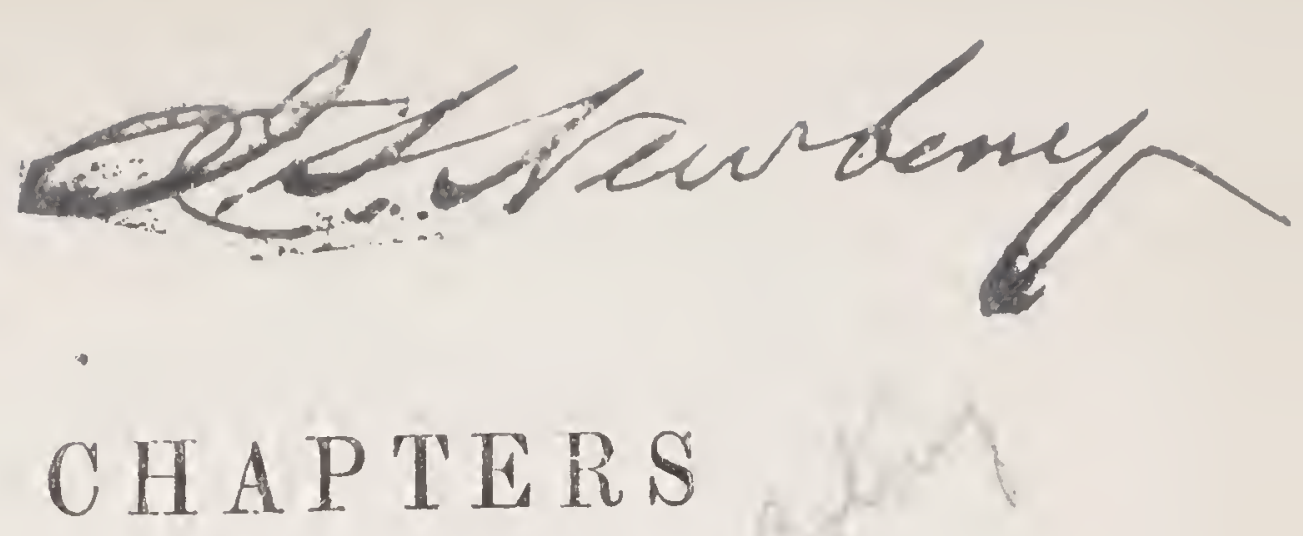

ON

FOSSIL BOTANY.

BY S. R. PATTISON, F.G.S.

LONDON:

SIMPKIN, MARSHALL\& CO. 
"Les phénomènes de la nature ne doivent pas être compris seulement d'après les lois de la matière, quelque bien combinées qu'elles soient; ils ont un sens philosophique et un but religieux, dont la contemplation la plus attentive ne pourra jamais connoître toute l'étendue."-De Staël De L'Allemagne, T'orne 2, p. 520. 


\section{PREFACE.}

THE present work is not intended to form a text book for the scientific student. Such a manual is much needed in the present state of our knowledge of fossil botany. It is hoped that the task of preparing it will be undertaken by some person possessing (in addition to other attainments) the leisure and facilities for reference to geological collections and publications, which a busy life and provincial residence do not allow to the author of the present treatise. Meanwhile a discursive exhibition of general views on the subject, may serve to induce a more widely spread inquiry into the facts of this modern science, and thus aid its onward progress.

The subject lies at present in a condition to demand and repay investigation. The pleasure of discovery may be added to the charms of pursuit.

\section{Launceston,}

September, 1849. 



\section{CONTENTS.}

\section{CHAPTER I.}

\section{PRELIMINARY BOTANY.}

Connexion of the Sciences. Structure of Plants. Divisions founded on Structure. Endogens and Exogens. Classification. Natural Groupes. Examples. Constancy of Species. Application to Geology. Theological References. Botanical Geography. Floral Provinces. Effects of Climate.

\section{CHAPTER II.}

\section{PRELIMINARY GEOLOGY.}

Course of inquiry as to Geological Truths. Early Observers. Modern Methods. First Results. Proofs of Succession in Strata. Non-fossiliferous Rocks. Silurian. Devonian. Carbonifcrous Strata. New Red Sandstone. Lias and Oolites. Green Sand and Chalk. London Clay. Sands and Gravcls. Mcaning of Succession of Deposits. Summary. 


\section{C.HAPTER III.}

\section{GENERAL VIEW GF FOSSIL BOTANY.}

Emmeration of Plants found Fossil. The Flowerless Class. Sonthern Type of Fossil Sea-Weed. Absenee of Mosses. Equisetum. Calamites. Ferns and Tree Ferns. Monotonous Charaeter of Aneient Vegetation. Fir Trees and their persistence throughout all Strata. Lepidostrobi. Lepidodendron. Palms and Cycadere. Sigillaria. Singular Arrangement of Branelies. Difficulties of the Inquiry. Conversion of Vegetable Matter. Wisdom of the Arrangements.

\section{CHAPTER IV.}

\section{SUPERFICIAL DEPOSITS.}

Reasons for Separate Treatment. Effects of Causes now in Operation. Peat Bogs. White of Selborne. Evelyn. Tin Deposits of Cornwall. Ireland. Submarine Forests on Coasts of Normandy, Cornwall, and elsewhere. Conneetion between these Deposits and Extinct Races of Animals.

\section{CHAPTER V.}

\section{FLORA OF TERTIARY AND SECONDARY ROCKS.}

Plan of Investigation. Loudon Clay. Sheppy Fruits. South American Fossil Forests. Amber. Flora of the Chalk and Greensand. Oolites. Portland Quarries and their Cycadean Remains. New Red Sandstone. 


\section{CHAPTER VI.}

\section{COAL FORMATIONS.}

Vegetation of the Coal bearing Strata. Enumeration of Families of Plants found Fossil. Remarks on the Scanty number of Genera. Difference of Aspect and Character from the Flora now around us. Facts and conclusions as to mode of Deposit. Roots of Trees and Upright Stems. Various Instances. Coal of other formations.

\section{CHAPTER VII.}

COAL MEASURES CONTINUED.

General view of Coal Measures in various parts of the Globe. Africa, Asia, Australia, America, Europe, and the British Isles. Mineralogy of Coal. Distortions of Strata. Faults. Advantages of actual Arrangements. References to history of the use of Coal. Statistics of the Subject.

\section{CHAPTER VIII.}

\section{BOTANY OF PALAOZOIC ROCKS.}

Difficulty of detcrmining between the Strata of older Rocks. Instance from Nortl Devon. Devonian System. Silurian. Cambrian. Paucity of Organic Remains. Plants in the old Red Sandstone. In thc Silurian and lower Rocks. Sea-Weed, Ancient and Modern. Earliest appcarance of Life, and remarks on its Character. 
xii.

CONTENTS.

\section{CHAPTER IX.}

\section{STATISTICS OF FOSSIL BOTANY.}

Difference between species the ground of our Researches. Modcrn rise of the Study. Table of Profcssor Göppert. Contrast with the present. Mr. Morris's Table of Fossils in British Strata. Other Tablcs. Rcriew and Conclusions.

\section{CHAPTER X.}

\section{CONNECTION WITH OTHER STUDIES.}

Union of all Sciences. Rclation of Fossil Botany to Geology . Botany. Mining. Chemistry. History. Physical Gcography. Connection with Moral Science. Natural Theology. Argument for design. Illustrations of higher truths. Harmony with Revelation. Temper of mind fostered. Earth a Necropolis.

SUPPLEMENTAL NOTE. 


\title{
CHAPTERS ON FOSSIL BOTANY.
}

\author{
CHAPTER I. \\ PRELIMINARY BOTANY.
}

Connexion of the Sciences. Structure of Plants. Divisions founded on Structure. Endogens and Exogens. Classification. Natural Groupes. Examples. Constancy of Species. Application to Geology. Theological References. Botanical Geography. Floral Provinces. Effects of Climate.

"While Idleness weaves

Her flow'rets together, if wisdom can see

One bright drop or two, that has fallen on the leaves

From her fountain divine, 'tis sufficient for me."

BEFORE commencing our researches into the archives of the past, it is requisite that we should furnish ourselves with some knowledge of the character in which its writings are recorded. There were no let- 
ters on the piece of mulberry wood found by Mr. Layard among the ruins of Nineveh, but it bore inscriptions in the peculiarities of its own structure, which enabled the discoverer to assign it a place amidst the things of life.

In the investigation of fossil botany, some acquaintance with the structure of living plants is necessary, since the principal discoveries in the one science are founded on the ascertained facts of the other.

We propose therefore to describe briefly the organization and mutual relations of existing vegetables, in order that we may proceed from the known to the unknown, and investigate the caverns of the earth by the light of a torch kindled at its surface.

"Order is heaven's first law," is the ill expressed utterance of the general truth, thas all the objects we see around us are connected together in a system of mutual relations. Thus there is an exact correspondence between the structure of a plant, and its situation; and a resemblance between every kind of plant, and some other kind. These phenomena are of indepen- 
dent origin; difference of situation alone will not produce a corresponding suitableness in the vegetation; nor will the mere variation between individual plants of the same kind, ever become specific differences; that is to say, differences perpetual and constant. These two facts, the adaptation of living structure to the varieties existing in soil and climate, and the relation of plants to each other, render the study of botany interesting to the theologian, as furnishing continual proofs of divine wisdom and power.

We intend in this chapter to give such an outline of elementary botany, as will lighten the toil of our subsequent journey amidst coal mines and quarries. The picture of present vegetation, in all its variety of colour and shade, will teach us to discriminate the features of that colourless dark landscape on which the fossil botanist gazes.

The internal structure of vegetables is constructed for a series of fluid movements, which are continually taking place in the vessels and valves of the plant, somewhat analogous to the nutrition and circulation in animals. 
In a few instances, such as the transparent stem of the chara, the internal current can be seen in motion, but in nearly all cases it is hidden from our view by opaque coverings.

If it were possible that the flow of the sap could be visible to us, what a scene would a forest tree afford, with its mighty branches, millions of tubes, and countless myriads of cells, all in alternate harmonious movement, the vital current flowing through them like the waters of the rising Nile occupying the channels of the Delta.

The interest of the phenomena is not exhausted by a consideration of the skilful mechanism of vegetables, but there is still the fact of the motion thus provided for and employed: that wonderful vitality which must be tracked by one mighty bound from finite to the infinite-from creation to the Creator.

As design is inferred from contrivance, so power may be inferred from motion, and the life-movement wherever witnessed is a testimony for the Almighty. 
"Not a tree,

A plant, a leaf, a blossom, but contains

A folio volume. We may read, and read, And read again, and still find something new;

Something to please, and something to instruct, Ev'n in the humblest weed."

The study of vegetable physiology, discloses to us that all plants are formed of a net work of matter called vegetable tissue. This substance is arranged in cells, which are laterally unconnected with each other, but in many instances prolonged vertically. These cells are frequently lined with spiral fibres. The simplest forms of the flowerless classes of plants are entirely thus composed, the surfaces being covered with a skin also thus constituted. The greater number of plants, including all save the lowest forms of cryptogamia, have an additional modification of structure, viz., tubular vessels, interspersed through their system; and hence such a composition is styled vascular. Nor are these appearances exhibited by the soft portions alone, the densest wood is made up of elongated cells, hardened by the accretion of solid matter, arranged in bundles or layers, and penetrated by various vessels. 
The skin of a plant has in addition to this structure certain orifices called stomata; the root has a distinct arrangement of vessels in the spongioles or absorbent organs in contact with the soil.

We can acquit Galileo of enthusiasm, in his celebrated reply to the officers of the Inquisition, on being accused of want of belief in a Supreme Being, when, pointing to a straw on the floor of his dungeon, he averred that from it alone he could infer with certainty the existence of an intelligent Creator.

All the vital influences of vegetable life are carried on through the tubular vessels, and some minor organs; currents of nutriment, sap, and air, are continually traversing the cells and intercellular spaces; whilst particles of more solid form are floating to their destined post, to strengthen and sustain further expansions of creative power.

The pores and vessels, though universal in their existence throughout the vegetable kingdom, are found to vary in size and arrangement; and these variations are sure guides to wide differences in the character of the plant. 
There are for instance three arrangements of woody fibre; the first and most usual, in which the sides of the cells are free from dots; the second, in which they are spotted with minute grains; the third, in which they have regular marks or glands. Our ordinary woods are composed of the first; the cycadean tribes and their allies of the second; and pine wood of the third. So constant and pervading is this distinction, that it may be detected even in a fragment of fossil wood; and thus is revealed the former state, and somewhat of the history of an obscure petrifaction. The microscope applied to a thin slice of carbonized matter sheds light upon its dark structure, and claims for it a rank among the pines, or palms, or forest trees of the earth. By the aid of such examinations most of the results of fossil botany have been attained. The simplicity of structure, and boundless variety of form, afford one of the proofs, so often met with in these studies, of the affluence of the Creator's wisdom, as displayed in his works.

Economy of causes, and prodigality of effects; simplicity of laws, and complexity 
of results; these appear to be the contrasts exemplified in all branches of natural history.

The differences which exist amongst the numerous trees and plants which adorn the earth, are grounded on differences in their minute organization. Thus, one province of vegetation is characterized by the absence of what is termed vascular tissue, and on the inhabitants of this province being classified together they are found to exhibit many other striking evidences of alliance. Those which are of a vascular structure, are again divisible into such as grow by additions to the centre; and such as increase by additions at the circumference; the former being called Exogens, and the latter Endogens. These are the three leading divisions of the vegetable kingdom; but as it happens that structural differences do not alone characterize plants, so some other variations are nearly as universal, and one especially - the form of the seed, is used to express the leading divisions equally with structure and mode of growth. Thus all plants are divided into 1 st, Dicotyledonous, having two seed lobes, as the bean: 2 nd, 
Monocotyledonous, having one only seed lobe, as the wheat; 3rd, Acotyledonous, having no seed lobe, but mere granules of seed.

As the stems of plants are those parts which are most frequently found in a fossil state, the most interesting and useful knowledge for their investigation consists of an acquaintance with the minute anatomy of wood. With regard to this, all flower bearing plants are arranged in the two leading divisions, Exogens and Endogens.

In the former, which we will name the bark-bearing plants, there is usually a pith composed of cellular tissue, a zone of hard wood composed of vascular tissue and divided by plates called medullary rays (consisting of compressed cellular tissue, ) and an inner and outer bark. The new wood is formed on the inside of the bark, and added as a layer to the outside of the former wood.

In the latter, which may be called the barkless plants, there is neither true pith, nor hard wood, nor bark. The bulk of the stem is composed of cellular tissue with vascular fibres imbedded. The new plant 
grows by additions to the interior and to the summit, in many genera not increasing in size with age. The progression of the tree is effected by the formation of fibrous matter at the base of the leaf, which on the decay of the latter is permanently added to the stem.

The principal differences which accompany the structural distinction between Exogens and Endogens are that in the latter (the barkless plants) the leaves are strait, and veined in parallel lines; in the former, the leares are more diversified in form, and the veins proceed from the central column. The seeds, as before noticed, are also different, and the distinct mode of branching and growth gives to each a separate character.

The trees of our climate are exogenous, and so are the majority of our flowering plants and shrubs. The grasses, tree-ferns, sugar cane, palm, and plantain, are examples of endogenous vegetation.

The ordinary exhibitions of the hydrooxygen microscope, the more familiar displays of less powerful magnifiers, and the 
inspection of the plates common in botanical works, have familiarized to most persons, the fact of the distinctly different structure displayed by various kinds of wood. No lace of human handywork, can rival the delicacy and perfection shewn in a section of any common woody stem. A comparison such as is sometimes exhibited between the finest productions of our looms and the section of a small branch, is decisive of the immeasurable extent of the distance between the skilful workmanship of earth's ingenious artisan, and that of heaven's Great Artificer.

"And yet was every faltering tongue of man,

Almighty Father! silent in thy praise,

Thy works themselves would raise a general voice;

Even in the depths of solitary woods

By human foot untrod, proclaim thy power,

And to the quire celestial Thee resound,

'Th' eternal cause, support, and end of all !"

If we admire the variety of simple elementary structure, thus exemplified in upwards of sixty thousand distinct forms, we shall find still more to excite our wonder in the concurrent changes exhibited in their aspect, character, and properties.

The florist, in laying out his garden, studies two elements of beauty, association 
and variety. In one portion his beds abound in contrast, whilst another division is dazzling with groupes of flowers of similar aspect and allied form. So the student of the works of creation possesses continually before him these two sources of interestvariety and order.

The reduction of the subjects of our consideration into certain assemblages possessing some appearances in common, would be a natural employment of the observer, and a considerable portion of the study of botany is occupied with its classification.

Botanists divide the whole vegetable kingdom into six classes:

I. Agame, or flowerless plants.

II. Cryptogamia Cellulares, plants composed of simple cellular tissue, with flowers concealed.

III. Cryptogamia Vasculares, in which distinct vessels are added to cellular tissue, and the flowers also concealed.

IV. Phanerogamia Gymnospermia, flowering plants with naked seeds.

V. Phanerogamia Monocotyledones, flowering plants with one-lobed seeds. 
VI. Phanerogamia Dicotyledones, flowering plants with two-lobed seeds.

This classification is natural, and is founded on characters which are constant, and pervade the whole structure. Thus by the aid of the microscope, we can discern that the arrangement of the minute vessels which compose the living plant, is essentially different in each class, and the smallest portion becomes sufficient to classify the individual to which it belonged. In applying this test to fossils, most satisfactory results are obtained. So indelible are the marks impressed upon living matter, upon that which has ever been the channel of the life bestowed by God, that they are conspicuous and discernible even amid the aged ruins of the coal mine, and after the violent process of combustion. The ashes of coal, when examined under a high magnifying power, display the original texture of the wood; and thin slices of mineral coal, subjected to the same scrutiny, reveal the secret of their birth. The boundaries between the vegetable and animal kingdom may be obscure, but the place where the former 
commences scarcely admits of question; the impress of those contrivances by which life in any form is sustained, plainly distinguish every particle of matter ever subject to its dominion.

The preservation of botanical character is owing to the process of fossilization, which has the effect of removing vegetabie substance, and supplying stony matter in its place, so that the latter is an exact cast of the former, not only shewing the outer form, but each separate vessel, and every structural arrangement. It is a cast, not as it were moulded at a single heat, but by successive minute processes, like the results of electrotype. Hence is produced a form, so strikingly identical with the living plant in material arrangement, that an inspection of fossil trees and leaves produces a feeling of the marvellous, as though the metamorphosis were a phenomenon of life and not of death.

Old Evelyn, in his Sylva, thus relates one of the early experiments of the Royal Society, the subject of which appears to have been a fragment of fossil wood. If the steps of 
the formal inquiry thus quaintly detailed, now excite a smile, it may be recollected that they display the early application of the Baconian method, by the employment of which so much of certainty has been subsequently attained in natural history.

"We did in chap. 21, mention certain subterranean trees, which $\mathrm{Mr}$. Cambden supposes grew altogether under the ground: and truly, it did appear a very paradox to me, till I both saw and diligently examin'd that piece (plank, stone, or both shall I name it) of lignum fossile taken out of a certain quarry thereof at Aqua Sparta, not far from Rome, and sent to the most incomparably learned Sir George Ent, by that obliging Virtuoso Cavalier dal Pozzo. He that shall examine the hardnesse, and feel the ponderousnesse of it, sinking in water, \&c., will easily take it for a stone; but he that shall behold its grain so exquisiteiy unalated, and varied together with its colour, manner of hewing, chips, and other most perfect resemblances, will never scruple to pronounce it arrant wood. "But, whiles others have philosophiz'd 
according to their manner upon these extraordinary concretions, see what the most industrious, and knowing Mr. Hook, Curator of this Royal Society, has with no lesse reason, but more succinctnesse, observ'd from a late microscopical examen of another piece of petrifi'd wood; the description and ingenuity whereof cannot but gratifie the curious; who will by this instance, not onely be instructed how to make inquiries upon the like occasion; but see also with what accuratenesse the Society constantly proceeds in all their experiments; and with what candour they relate and communicate them.

'It resembl'd wood, in that

'First, all the parts of the petrifi'd substance seem'd not at all dislocated, or alter'd from their natural position whiles they were wood; but the whole piece retain'd the exact shape of wood, having many of the conspicuous pores of wood still remaining pores, and shewing a manifest difference visible enough between the grain of the wood and that of the bark; especially, when any side of it was cut 
smooth and polisht; for then it appeared to have a very lovely grain like that of some curious close wood.

' Next it (resembl'd wood) in that all the smaller and (if so I may call those which are onely to be seen by a good glasse) microscopical pores of it, appear (both when the substance is cut and polish'd transversely, and parallel to the pores) perfectly like the microscopical pores of several kinds of wood, retaining both the shape, and position of such pores.

' It was differing from wood.

"First, in weight, being to common water, as $3 \frac{1}{4}$ to 1 whereas there are few of our English woods that, when dry, are found to be as full as heavy as water.

'Secondly, in hardnesse, being very near' as hard as a flint, and in some places of it also resembling the grain of a flint: it would very readily cut glass, and would not without difficulty (especially in some parts of it) be scratch'd by a black hard flint : it would also as readily strike fire against a steel as also against a flint.

$$
\text { C } 5
$$


"Thirdly, in the closenesse of it; for, though all the microscopical pores of the wood were very conspicuous in one position, yet by altering that position of the polish'd surface to the light, it also was manifest that those pores appear'd darker than the rest of the body, onely because they were fill'd up with a more dusky substance, and not because they were hollow."

The most obvious divisions which obtain in the vegetable kingdom, are those which are manifested in external form. The classification, called the natural systern, reckons about two hundred and seventy two families or tribes. A specimen of one or two of these will suffice to shew the characters usually relied on to serve as the basis of the leading divisions.

The heath tribe for instance, comprising the well known ornamental erica, rhododendron, azalea, and other forms, all evergreen shrubs, having a uniform resemblance in the number and position of their organs, and a common character and habit of growth, flourishing mostly in southern Africa and almost unknown in Australia. 
The lily tribe, constituted of bulbous rooted plants, with beautiful large flowers, regular in the exhibition of six stamens and one central style, and having seeds imbedded in a soft substance.

The grasses afford another familiar illustration of this arrangement. The wheat and meadow grass of our climate, are bounded on the north by rye, oats, and a more mossy herbage; while on the south they are superseded by maize, rice, and large leaved grasses of ranker growth. There are upwards of eight hundred species of this invaluable tribe, all connected by common characters, and all associated in a general utility. They constitute about one part in twenty of the actual vegetation of the globe, and their large adaptation to the sustenance of man and of domesticated animals, renders their wide distribution a circumstance worthy of admiration. In the language of "rare" Ben Jonson, "The order of God's creatures in themselves is not only admirable and glorious, but eloquent."

There is one truth which lies at the 
threshold of all useful investigation of these subjects, and that is the absolute constancy of species. The oak tree for instance, is, under all circumstances, and has been through all recorded time, a distinct kind of tree having leaves, stem, flower, and fruit, differing from all others, and bearing seed "after his kind" alone; and which differences though raried in amount by cultivation or climate, yet never become obliterated or confounded. This is also true in the animal kingdom; so that the existence of distinct, and constantly distinct kinds of living creatures, is to be assumed as an ultimate fact in all our reasonings.

Species thus resemble the alphabetical letters; the type may vary in form, may be Roman or Italian, but the character and power of the thing signified remain the same.

There are instances of very wide diversity produced by circumstances in separate individuals of the same family, but it is undoubtedly established that such differences are transient, sometimes enduring for one generation, sometimes for a longer 
period, whilst the specific distinctions are essential and of perpetual recurrence.

Hence we advance with firm footstep into the domains of the dead, and are able, amidst the organisms of the past, to pronounce with confidence concerning the true character of the relics, and to declare that they are distinct forms, not derived through any transmutation of species from others, nor were they themselves the progenitors in any such fabulous descent. God made every living thing in its kind; and in this respect, so long as the race exists, as it was in the beginning, so it is now, and so it ever shall be. There may be a chain of being, there may be circles of affinity, there may be gradation of type, but the caste of the specific distinctions is and ever has been an unbroken boundary.

"But cliangeful and unchanged the while

Your first and perfect form ye show, The same that won Eve's matron smile

In the world's opening glow." -Keble.

Having thus referred to structural and systematic botany, as far as our subject and 
limits require, it remains that we allude to another subject of investigation connected with the present flora of the earth, namely botanical geography. The minor differences which afford remark as we pass from the sylvan scenery of one part of England to that of another, or as we admire the wild flowers common in one place and scarce in another, are the types of variations more extensive and complete throughout the world. The arrangem ent of plants, which actually obtains over the globe, cannot be entirely accounted for by considerations of climate, temperature, and soil.

The well-known prevalence of particular kinds of plants in certain districts, has led to the attempt to divide the whole earth into floral provinces, each distinguished by characteristic vegetation. This novel kind of geography is best delineated in an elaborate work by a Danish professor, Mons. Schow, * who reckons twenty-two great divisions of the globe, each sub-divided into lesser provinces. His first region is that of 
mosses and saxifrages, comprising all the Arctic and all the Alpine localities, and characterized by mosses, lichens, gentians, saxifrages, and similar forms. The second region is that of cruciferous plants, extending from the Arctic circle, and from the lower limits of Alpine forms on the mountains, over the whole north of Europe, including the British Isles, and part of northern Asia. There are about nine hundred species of which five hundred and forty-eight are found in the temperate regions of the northern hemisphere, comprising the turnip, cabbage, and other cornmon vegetables. The third province, that of the mint tribes, or the midland flora, comprises the countries bordering the Mediterranean, and in this province tropical forms first make their appearance. Fourth-Japan and the adjacent continent, the region of the buckthorn and honeysuckle tribe. Fifth-The eastern part of North America. Sixth-The southern part of North America, the region of magnolias. Seventh-Mexico and the West Indies, the region of the cactus and the palm. Eighth 
- Peru, the region of the quinine and feverbark trees. Ninth-The Highlands of South America, with their handsome evergreen shrubs. Tenth-Chili, the land of calceolarias. Elerenth-Buenos Ayres and the eastern coast of South America, distinguished by peculiar flower-bearing trees. Twelfth-the Antarctic circle. Thirteenth -New Zealand. Fourteenth-New Holland, the country of gum trees and peculiar forms. Fifteenth-South Africa, the home of the eucalypta and heaths. SixteenthWestern Africa. Seventeenth - Eastern Africa, rich in ferns. Eighteenth-India, characterized by the beautiful and useful trees of the ginger tribe. Nineteenth-The Indian highlands. Twentieth - Cochin China. Twenty-first-Arabia and Persia, rich in spices, and ornamented by the "yellow-haired" acacia. Twenty-second--The South Sea Islands, the region of the bread fruit.

The enumeration above given does not comprise all the families which Professor Schow considers characteristic, but only a specimen of them. It is interesting as 
indicative of the wise order manifested in the distribution of these floral riches.

Every portion of creation, in all aspects, by its evidences of design, is calculated to redeem us from low views concerning the nature and methods of God's government, and to shew us that all things are arranged and maintained according to vast comprehensive plans.

Many exceptions might be taken to the particular divisions above-mentioned, but they would not affect the general truth thus indicated, that throughout the globe certain plants are most abundant in particular districts, and are not common universally, or even under the same parallels of latitude.

We shall find that this conclusion will be material in estimating the amount of resemblance between the condition of things in former epochs of vegetation, and at present.

The effects of climate on vegetation is illustrated not only by the horizontal variations between different portions of the globe, but also by vertical differences under the same parallel, as exhibited on the mountains of the tropics. 
We extract Humboldt's picturesque description of the scenery of the mighty Andes.

"In the burning plains, raised but little above the level of the southern ocean, we find, in their greatest luxuriance, Bananas, Cycadeas, and Palms; after them, shaded by the lofty sides of the vallies, arborescent Ferns, next in succession, in full plenitude of growth, and ceaselessly bedewed by cool misty clouds, the Cinchonas, which yield the far-famed and precious febrifuge barks.

"Where lofty trees no longer grow, we meet with Aralias, Thibaudias, and myrtleleaved Andromedas, associated and blooming in company. The Alpine rose of the Cordilleras, the Befaria rich in resinous gum, form a purple belt about the mountains. In the lofty region of the Paramos, all the more lofty vegetables, and large flowering berbs, gradually disappear. Glumaceous monocotyledonous tribes now cover the surface without variety, and form unbounded meadows, looking yellow in the distance, where the Llama sheep is seen feeding in solitude, and the cattle introduced by Europeans roam in herds. Upon the naked 
masses of trachytic rock, which here and there rise above the surface of the turfclad soil, none but plants of the lowest organization can thrive; the tribe of liverworts which the atmosphere now of greatly diminished density and containing little carbonic acid supports but sparingly: Parmelias, Lecideas, and Leprarias, with their manycoloured sporules, form the flora of this inhospitable zone. Patches or islets of lately fallen snow now begin to cover the last efforts of regetable life, and then sharply defined, the line of eternal ice begins."*

The botany of the ancient earth does not display to us such a varied picture as that just exhibited.

Although the researches of geologists are too limited to enable us to conclude witb certainty on the extent of former vegetation, yet they are sufficient to enable us to state that there was greater uniformity in the conditions of former life, and more monotony in the character and aspect of the foliage. 


\section{CHAPTER II.}

\section{PRELIMINARY GEOLOGY.}

Course of inquiry as to Geological Truths. Early Observers.

Modern Methods. First Results. Proofs of Succession in Strata. Non-fossiliferous Rocks. Silurian. Devonian. Carboniferous Strata. New Red Sandstone. Lias and Oolites. Grcen Sand and Chalk. London Clay. Sands and Gravels. Meaning of Succession of Deposits. Summary.

"Why mot indulge such thoughts as swell our hearts With fuller admiration of that power, Who gives our hearts with such high thoughts to swell? Why not indulge in his augmented praise? Darts not his glury a still brighter ray The less is left to chaos, and the realms Of hideous night, where fancy strays aghast; And, though most talkative, makes no report ?"-Young.

The history of science shews that philosophers have been more commonly found trying their powers at the circumference of the circle of human knowledge, than cultivating the space within; like birds in 
confinement, which whet their beaks, and wear their wings, in the ineffectual attempt to escape from the bars of their prison-house. Hence the prevalence of lofty but barren speculations during the infancy of moral and physical science, and hence the tendency to prefer discursive arguments respecting the origin of things, to the description of the things themselves. In no department of learning has this ambitious habit of the mind been so conspicuously displayed as in the study of geology. We run the risk of taking our science out of the catalogue of interesting topics, when we claim for it the humble place of being chiefly a repertory of facts as they are; and assign to it, as a secondary office only, the task of aiding in the construction of theories of the earth.

Nor ought the simple object of registering natural phenomena, to be despised as beneath the dignity of our nature, or the design of our faculties.

Every display of intelligence in the works of creation may minister both to the increase of our knowledge and the excitement of devout feelings. Although true piety can

D 5 
neither be created nor supported by such studies alone, yet an intëlligent religious habit may find much in geology that is well calculated to gratify and improve the mind. If the enduring works of the Roman, or the rude monuments of the ancient Briton, have charms for the antiquary, irespective of intrinsic beauty or fitness, how much more attractive should be those relics, which are not only connected with the highest associations, but are in themselves manifestations of exquisite because of infinite skill.

No sooner did the early observers notice differences in the materials of which the earth is composed, than theories in quick succession vied with each other in the demands which they made upon the imagination and faith of mankind. The romances of the cosmogonists had the double demerit of being violations both of physical and of revealed truth. Hence arose the obloquy which formerly attached to these pursuits; and if our science has had a verdict of acquittal, on its trial for infidel tendencies, we may be excused for prizing the more highly a reputation which has been fully vindicated in a solemn ordeal. 
It is therefore the distinctive merit of modern geology, that it has'earned its title to the applause of the wise and good, in spite of strong opposition and mistrust; the latter originating in a jealous fear for the honor of other truths, deservedly dearer to the applauders, than all the world contains besides.

We will not further allude to the theories of the world-makers which have thus raised our science to a "bad eminence," but endeavour simply to delineate an outline of the plain undeniable facts written in the earth beneath.

The first observation of the enquirer will be that the subsoil is not every where composed of the same substance; next, that there is variety in the arrangement as well as in the materials ; thirdly, that the variations have some law and order; fourthly, that different portions of the subsoil are not only characterised by difference of mineral character and position, but by a diversity in the forms of organic fossils which they contain.

The proof of succession in the order of deposits is complete, not only as it is de- 
duced from actual explorings made at the edges of the strata, but from an examination of their constitution. Many hard rocks are formed of gravel or sand, the worn down fragments of pre-existing rocks. The old red sandstone contains pebbles of the rock on which it rests; the new red sandstone contains pebibles of the old red; the upper gravel include pebbles of both these, and of the chalk lying between them, but this order is never found to be reversed, we never find pebbles of chalk in the red sandstone; and hence we have the same kind of assurance that the strata were successively and separately consolidated, as we have that the pebble beach of our coast is of subsequent origin as a whole, to the cliffs whence its fragments fell.

The chief interest of modern geology is derived from the indisputable fact, that the solid strata of the earth are characterized by peculiar fossil organic remains, that each one has its own distinct cabinet of botany and zoology.

The investigation of organic remains has now taken the place of former speculative 
enquiries; and if it deals with rigorous facts alone, yet there are among them truths "stranger than fiction."

The distinctions usually made between strata, may be therefore regarded as beirng established upon the joint evidence of mineral differences and organic contents.

One important class of rocks is universally destitute of all traces of former life.

This is a discovery of the old geologists which their successors have not been able to set aside; Granite, and the rocks of similar structure, are in this condition, and so are gneiss, mica-slate, and some other substances which nevertheless occur in layers like the fossiliferous rocks. The granitic series bears the impress and marks of former fusion. Basalt, greenstone, porphyry, and similar substances, are usually termed trap rocks, and are for the most part analogous to the modern volcanic products, lava, trachyte, and pumice. The non-fossiliferous slate rocks are found resting against the granite, or forming the base of a platform of fossiliferous deposits.

Although the moderns have not removed non-fossiliferous rocks from the catalogue, 
yet they have greatly narrowed their number. A few years ago the slate system of Cornwall, in which the inineral veins occur, was announced to be primitive and devoid of organic forms. Subsequent observation has traced the structure of corals and shells up to the very walls of the metallic lodes, and shewn that the whole series was deposited coeval with the existence of marine animals. In like manner elsewhere, the result of minute observation has been to enlarge the boundaries of the world of ancient life, and to diminish the lifeless territory of pure physical force.

The fossiliferous rocks and beds constitute a list formidable in the detail of its numbers, but not difficult to divide into a few leading groupes.

If for instance we use a local illustration, and take the granite of the south western promontory of England as a base, we find inclining against it a series of coarse slates, including thin beds of limestone and remains of marine shells. The lower portion of this series is distinguished by one set of fossils, and named the Silurian system; the 
upper by a different set of forms and called the Devonian; resting on these, and differing but little in general aspect, occurs a succession of clays and hard strata with dark limestones at the base, now termed the Coal measures.

On reaching Exeter we find the latter overlapped by masses of variegated sands and dark blood-red rocks, termed the new Red sandstone, and at the northern edge of this the blue Lias is superimposed, with its well known upper associates the Bath stone, Portland stone, and Oolites. Over these the Greensand forms a groupe, manifestly distinct, serving as a basis for the well-marked Chalk, and upon the latter the dark clays of London, the sands of Windsor forest, and the gravel of Blackheath rise to complete the series.

Many minor details are omitted in this enumeration; a glance at a geological map or table, or better still, a notice of the railway cuttings on a journey, will serve to convey the outline truths of descriptive geology more easily than a lengthened enumeration of formations.

It should he borne in mind that these strata are either composed of hard rock 
regularly bedded, from having been deposited layer by layer in water, or of fine sand, or coarse gravel.

The proof of their succession is derived from the fact of their dipping the one beneath the other, like the tiles of a roof. The evidence of their order is that wherever any two members of a series occur, they invariably occupy the same relative position. Thus the traveller who journeys from London to the Scottish border, to the Welch frontier, and to the Land's End in Cornwall, will in each case pass over different suites of rocks, some of which are altogether absent on each line; but wherever in more than one journey, the same kind of rocks or formations were visible, they would be found occupying the same position with regard to each other.

The proof of separation and succession derived from mineral aspect, and from relative position, is remarkably strengthened by an examination of the organic contents of the strata; a very casual survey of these, will force upon the observer the wonderful truth that each layer of terrestrial substance 
is characterized by a distinct and different set of the remains of former life.

We forbear to lengthen this sketch by details which may be easily found elsewhere, and conclude it with the eloquent words of one of the masters of the science.

"By the discoveries of a new science (the very name of which has been but a few years engrafted on our language), we learn that the manifestations of God's power on the earth have not been limited to the few thousand years of man's existence. The geologist tells us, by the clearest interpretation of the phenomena which his labours have brought to light, that our globe has been subject to vast physical revolutions. He counts his time not by celestial cycles, but by an index he has found in the solid framework of the globe itself. He sees a long succession of monuments each of which may have required a thousand ages for its elaboration. He arranges them in chronological order; observes on them the marks of skill and wisdom, and finds within them the tombs of the ancient inhabitants of the earth. He finds strange and unlooked-for 
changes in the forms and fashions of organic life during each of the long periods he thus contemplates. He traces these changes backwards through each successive era, till he reaches a time when the monuments lose all symmetry, and the types of organic life are no longer seen. He has then entered on the dark age of nature's history; and he closes the old chapter of her records. This account has so much of what is exactly true that it hardly deserves the name of figurative description."

* Sedgwick's Discourse on the Studies of the University. 


\section{CHAPTER III.}

GENERAL VIEW OF FOSSIL BOTANY.

Enumeration of Plants found Fossil. The Flowerless Class. Southern Type of Fossil Sea-Weed. Absence of Mosses. Equisetum. Calamites. Ferns and Tree Ferns. Monotonous Character of Ancient Vegetation. Fir Trees and their persistence throughout all Strata. Lepidostrobi. Lepidodendron. Palms and Cycadæ. Sigillaria. Singular Arrangement of Branches. Difficulties of the Inquiry. Conversion of Vegetable Matter. Wisdom of the Arrangements.

"Nor to the surface of enliven'd earth, Graceful with hills, and dales, and leafy woods, Her liberal tresses, is thy force confin'd : But, to the bowel'd cavern darting deep, The mineral kinds confess thy mighty power."-Thomson.

There are about eighteen hundred different kinds of plants discovered imbedded in the earth in a fossil state. They occur, for the most part, in very numerous assemblages of individual forms, so that the num- 
ber of species, is but an imperfect indication of the actual number of specimens.

The mode of preservation differs between the mineralization of a solid substance, as coal, or limestone, to the scarcely altered condition of the leaf in amber, or of the trunk in the peat bog. Sometimes the plant is only represented by a tracing of its surface, but most commonly by a cast of the whole substance, effected by a gradual removal of the organic matter, and the slow substitution of inorganic.

We will commence our catalogue of plants with those of simplest form, but before doing so must state the range of our intended researches. The term fossil includes all substances lifeless and buried; but in reference to geology, it is often used to describe only the organic remains contained in strata not now in process of formation, and in this limited sense it will be employed in our enumeration of the members of the ancient flora.

I. Two families of the first or flowerless class are found fossil; the conferva, small moss-like plants growing in the water, and 
the alga, the well known sea-weed. The former appear in the lower chalk, and also in the limestones of Paris. The genera of the latter vary with the temperature, some tribes flourishing in equatorial seas, and others being confined to the arctic zone. In the coal mines of Sweden we find the Sargassum, which now only comes to us as a stray weed from its ocean home in the tropics; the amansia, a form from the torrid zone, and the caulerpa of southern type, are discovered in the slates and sands of our own country, and the species impressed on the Paris limestones are of temperate habitation. Thus we have evidence that the depths of some of the ancient seas and rivers were decorated with waving foliage like that which now imparts beauty to many a solitary bay and lonely strand on the margin of the present world of waters.

II. The second class of plants, the cellular cryptogamia, is of little consequence in the ancient flora. One or two instances are mentioned of mosses being found fossil in the upper or tertiary deposits only; thus by their absence harmonizing with other evi- 
dence to shew the presence of a hotter climate during the formation of earlier deposits. These fibrous coverings, so benefical to the earth under a low temperature, are neither found nor required in tropical regions.

III. The third class is of great geological interest, the Equisetacec. One of its families is known to us in this country by its representative growing in our meadows, the Horse-tail, a little cane-like plant rising amidst the grass in the ditches, and attaining a few feet in heighth, which is increased to a maximum of twelve feet in equinoctial marshes. In the Lias, the blue building stone of north-east Yorkshire, are vertical stems of a similar kind, and they are also sparingly found in the coal measures. But our little marsh plant is more abundantly represented by the numerous calamites of the coal. Jointed cylinders with frequent divisions, and corduroy-like stripes, once hollow and succulent, but now flattened and filled with sandstone, are common at nearly every pit's mouth in the carboniferous district, and are even distinguishable amidst 
the barren clays of North Devon. It is difficult to imagine the former existence of luxuriant vegetation in many of the heath covered spots where their remains now prevail. As we have turned up these chiselled fragments of Indian growth in some slate quarry amidst our moorland districts, they have come to us like unexpected couplets of poetry amidst a world of prose.

The calamus was contemporary with the earliest vegetation of which earth affords us a record; it became extinct on the floor of the new red sandstone, and its smaller ally the equisetum succeeded it, and persists to the present day.

The next family is that of the Ferns, whose graceful feathery forms, giving elegance to the foreground of the wildest landscapes are familiar to all. They are found in every region of the globe, but wide distinctions obtain between species in different climates. With us, although varied and beautiful in outline, yet they are of subordinate magnitude, compared to their development in hotter climates, where they become arborescent, and attain a height of 
thirty feet. The tree-ferns have an appearance which effectually distinguishes them, and forms a valuable characteristic in the fossil state, namely the regular marks on their surface, produced by the periodical fall of the leaf. These impressions vary with the different leaves of each sort, and as they are symmetrically arranged, and of regular form, they add greatly to the beauty and ornament of the tree.

Fossil ferns from the coal strata chiefly belong to these arborescent kinds, though none are identical with existing species.

Those of our readers who have visited the British Museum, will recollect to have seen on the principal staircase, the withered trunks of two tall tree-ferns from the Brazils, with a small crown of leaves, and large rough scars on the surface of the stem. Individuals of the tribe which thus furnishes us with rarities for the Museum, formerly grew where Northumberland and Somersetshire now extend over the buried treasures of the coal. Such stems, though comparitively rare in a fossil state, are yet most decidedly present in that condition, as 
their peculiarities are too numerous to render a mistake probable in assigning their true character.

Many of the ancient ferns appear to have been water plants, as is the case with the next family, the Marsiliacea, a race of small freshwater weeds to which has been assigned the pretty little fossil leaves called Sphenophyllum found amidst the coal; and the representatives of another family, the chare of our present pools, are found in the clay and limestone beds of central France.

This extinct vegetation as it is now restored in imagination, or as we see it depicted in engravings, exhibits a very naked aspect compared with the leafy foliage of the present. The paucity of the kinds, combined with the reed-like nature of their growth, contrasts with the boundless profusion of form now adorning the landscape. We begin to perceive traces of the "great argument," which proves all former stages of organic existence to be but introductory to that better furnished platform, whereon a being endowed with mind was to be placed amid scenes calculated to win admiration, gratitude, and love for the bounteous Giver. 
"Thou art $O$ God the life and light Of all this wondrous world we see!

Its glow by day, its smile by night,

Are but reflections caught from thee!

Where e'er we turn thy glories shine,

And all things fair and bright are thine."-Moore.

IV. The fourth great division includes the Fir tribe, and the Cycadice, the latter a race of low palms growing in warm climates, and found in great numbers in the Oolitic series of England, imbedded in the quarries which furnish the common Portland stone.

Firs are easily distinguished by the cones and peculiar leaves which they bear; their geographical range is co-extensive under ever-varying forms with that of vegetation itself, and the same may almost be said of their geological occurrence.

Pine wood is found in all the bogs and submerged forests of our island, but it is all of one species the common Scotch Fir.

Below the superficial deposits, and amidst the gravels of still earlier date, in the lacustrine deposits of the upper tertiary, cones and wood of this order are discovered, the Oolite furnishes the yew and the cedar, the red 
sandstone contributes the voltzia and the cypress, the coal measures display the lofty araucaria, or a similar tree to that which forms the noble pine of Norfolk Island.

The hard fruit of the fir and other conebearing trees, is well calculated for preservation, and accordingly we find cones of many kinds figured in the works on fossil botany, under the name lepido-strobi. The impressions are frequently as fresh as those which would result from the recent productions of our woods, and indicate as well the cones which have periodically fallen, as those which have been prostrated with the parent tree. Polished sections shew the seeds in the cells, arrested and sealed up in their stony envelope, never again to spring into living foliage, but still for ever bearing proofs of Almighty workmanship and skill.

The coniferous remains, though not identical with any species now existing, yet appear as familiar friends amidst the strange forms with which they are associated. The noble aspect, and useful qualities of the fir, renders it, in one species or another, an important production in every part of the world. 
In this class we may place provisionally those remarkable trees called Lepidodendron, which graced the forests of the coal era.

These have been usually referred to the genus Lycopodiacia, the club mosses; but although we may not argue against such a position from incongruity in size alone, yet even amidst the widest variations from the present order of things, such an association would still be remarkable as that which brings into one family the lofty forest tree, rising sixty feet high, and the puny moss growing at its feet. The principal external characteristic of the species is its ornamental stem, produced by spiral rows of small eminences, the scars of the leaf stalk.

A trunk of seventy feet with sculptured decorations adorning its surface, and thence extending along numerous branches, terminated by few and narrow leaves fastened by a strong stalk, presents a picture unknown amidst the forests of the world at the present time. A recent observer has from their internal structure ranked them with the common house-leek, but whilst their 
importance in former ages of the world is universally admitted, their preeise rank amidst their sylvan brethren has not yet been fully determined.

The club-mosses, supposed to be their modern allies are flowerless weak plants, with the habit of mosses, growing abundantly in the humid islands of the tropics to the height of two or three feet. It is difficult to conceive of these as the successors of the beautiful large ornamental trees of the coal measures figured as Lepidodendra. Professor Lindley regards these trees as constituting one of the lost links in the present vegetable kingdom, a race intermediate between the fir-tribe and the club-moss : probably flowerless palms.

Their internal structure differs from that of all other plants, but possesses considerable analogy with the well known constitution of the pine tribe.

The fruits and forms of Lepidodendra are preserved in great delicacy and profusion in the Oolite shale of Gristhorpe Bay in Yorkshire. $*$

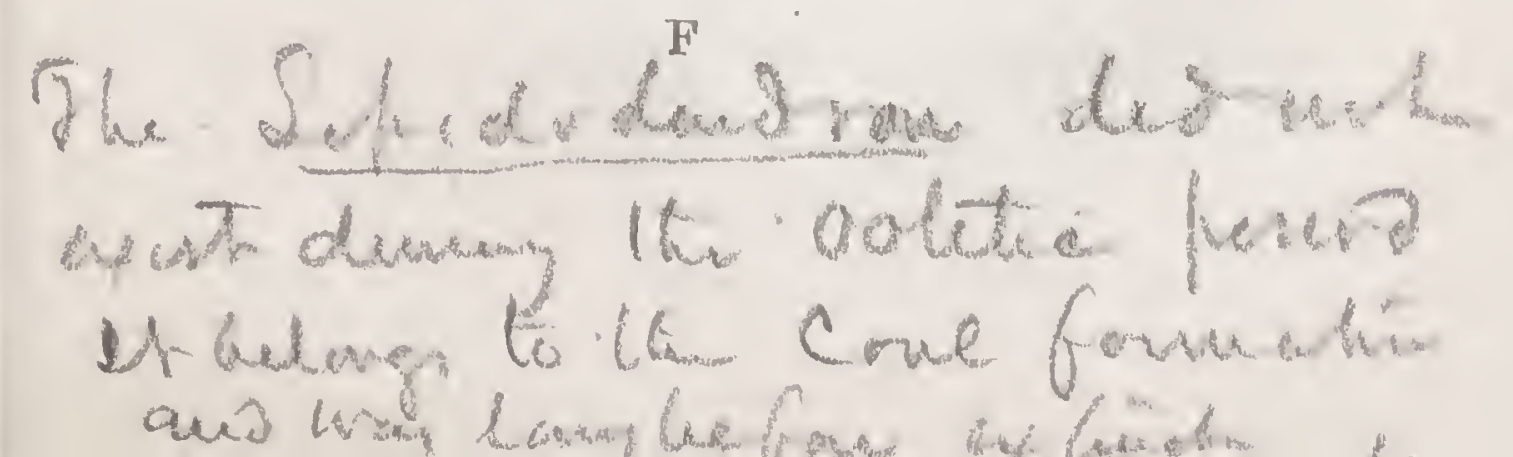


A noble example of this family is figured in Lindley and Hutton's Fossil Flora, plate 203, being the representation of a fossil tree found in the Bensham Coal seam in the Jarrow colliery, and which happening to lie on the direction of the gallery, was exposed throughout its whole length. The trunk is thirty-nine feet long, before its division into branches, and three feet across within the bark.

V. The fifth great division, plants with flowers and one-lobed seeds, comprises palms and grasses. The latter are absent from the fossil flora save some aquatic kinds, of which leaves and stems are present in the tertiary and greensand deposits.

The Palms with their striking aspect, historical associations, and economical uses to man, furnish matter for irıteresting research. They range in modern geography from the South of France and Spain to the Equator, become fruit-bearing trees on the southern shores of the Mediterranean, and attain their greatest developement in the forests of South America, where the Cucurito throws its 
magnificent leaves over a trunk a hundred feet high.

In the more ancient geography they may be mapped as adorning Central France, and fringing the estuary of the Thames at Sheppey with abundant foliage.

Many tribes of mankind in South America, Africa, and the Pacific Islands, derive the whole of their maintenance and shelter from the palm. Before Columbus ventured on his first voyage, the inbabitants of the Azores had seen carved blocks of this wood thrown on their shores by the western currents, telling them that man and his "food convenient" existed beyond the great waters, but there are no such relics to startle the observer on geological shores. Amidst the most abundant vegetation of former periods, we do not discover one single instance of the occurrence of a fruit adapted to the subsistence of man; but we discern amidst the absolute changes of organic life in the succession of deposits, some approximations towards the present state of things. The Cycadean groves and palmy coasts of the middle age of geology, were merely piepar- 
atory to the long subsequent introduction of him to whom Godgave " every tree in which is the fruit of a tree yielding seed."

\footnotetext{
"Thy ways O Lord, with wise design,

Are framed upon thy throne above, And every dark and bending line,

Meets in the centre of thy love!"
}

Plants of the Cycadean family are now natives only of the tropics of Asia, America, and south-eastern Africa. In our climate they exist amongst the rarities of the conservatory, in which character some fine specimens may be observed amidst the groupe of wondrously strange forms in the hot-houses of the Horticultural Society at Chiswick. The external appearance of these plants led to their being classed by Linnæus with ferns, they were afterwards separated to form a family intermediate between these and palms, but their structure has been determined to ally them more nearly with the fir tribe.

The occurrence of these curious forms where now the cliffs of Portland Island expose their barren crests to the shore, is 
one of the wonderful revelations of our science; the large leaved Zamia (ZZ.gigas) has also been found in the Oolitic rocks of Scarborough, three feet in length. These vegetables are undoubtedly witnesses for the former prevalence of a hotter temperature where they appear to have flourished.

"However remote may have been the time when these prototypes of the family of Cycadeæ ceased to exist, the fact of their containing so many combinations of peculiarities, identical with those of existing Cycadeæ, connects these ancient arrangements in the physiology of fossil botany with those which now characterise one of the most remarkable families among existing plants. In virtue of their peculiar structures, the living Cycadex form an important link which no other tribe of plants supplies, connecting the great family of Coniferæe with the family of Palms and Ferns, and thus fill up a blank which would otherwise have separated these three great natural divisions of dicotyledonous, monocotyledonous, and acotyledonous plants.

$$
\text { F } 5
$$


"The full development of this link in the secondary periods of geological history, affords an important evidence of the uniformity of design which now pervades, and ever has pervaded all the laws of vegetable life. Facts like these are inestimably precious to the natural theologian: for they identify as it were the artificer, by details of manipulation throughout his work. They appeal to the physiologist in language more commanding than human eloquence: the voice of very stocks and stones, that have been buried for countless ages in the deep recesses of the earth, proclaiming the universal agency of one all-directing, all-sustaining Creator in whose will and power these harmonious systems originated, and by whose universal providence they are and have at all times been maintained." *

Traces of the next tribe, the Liliacea are found from the coal upwards. The tropical forms of the Yucca and its allies, now objects of admiration in our conservatories, 
were once and repeatedly common forms in our land.

We may here too describe the Sigillaria, that companion of the Calamite and Lepidodendron, whose place is still uncertain in systems constructed on the basis of present phenomena. This was another monarch of the woods, marked with deep furrows and round scars. It is said to resemble a lofty cactus, or Zamia, with wide-spreading roots, the latter from their external ornaments, long considered to be a separate plant and called Stigmaria.

Fossil remains of these trees are exceedingly numerous, and in very many instances they are discovered vertical to the floor of the strata in which they occur.

There are upwards of fifty species, all with deeply fluted dotted stems. Their colossal forms, scantily crowned with fernlike leaves, have largely ministered in the formation of coal. The trunk, once hollow or filled with succulent matter, is now a pillar of sandstone, having apparently been broken off and filled from above. 
It appears strange that so ornamental a stem as that of Sigillaria should be only found in a fossil state. None amidst existing forms is comparable to it in its beautifully carved flutings, and seal-like spots in regular relief.

How inconceivably opulent is creation, seeing that it can thus as it were afford to bury its myriads of specimens, to entomb whole races, and yet to produce by forms totally different, the same picture of varied beauty!

Geographers, in describing the manners and customs of the Chinese, frequently sketch the contrast which subsists between them and the people of the western world, in order to give interest to their narrative by the opposite characters of the two delineations.

Geologists, in depicting the past, may often offer such contrasts to the observer; but as in the one case we do not think of thereby concluding that the laws of human nature, or its properties, or its Creator, are different; so neither in the other are any such conclusions respecting animal or vegetable nature admissible. 
There are a few succulent plants, and these only, which at the present day have their leaves arranged in any other manner than horizontally around the stalk. But in the fossil flora, the bulk of the examples have leaves disposed like the Sigillaria in strait lines up and down the stem.

This peculiarity, combined with the diminished size of the leaves, gives an air of stiffness to the pictures of former vegetation. We miss the profusion of graceful foliage which clothes the present forest in rich and beautiful attire.

VI. In the sixth class, dicotyledonous flowering plants, which are beyond measure the most abundant now on the face of the globe, geology has only a brief lesson to teach. Whilst nine tenths of the trees, flowers, and fruits, which supply our wants and minister to our enjoyment, are derived from plants of this order, yet in the ancient world, the subject of our present investigations, we find but few traces of their existence. Some doubtful specimens from the thick monocotyledonous forests of the coal field, are succeeded by a few fragments in the supe- 
rior formations, increasing to abundance in the upper tertiary beds. The latter contain wood of the beech, chesnut, poplar, willow, and other kinds similar to the forest flora of Europe at the present day.

Such is a cursory and (owing to the absence of plates and to limited extent) an imperfect account of these botanical treasures.

If the investigation be deemed uninteresting from the fewness of its subjects, it should be recollected that the inquiry is prosecuted under circumstances unfavourable to their preservation and discovery.

That beautiful provision of Providence, by virtue of which the living bury the dead, which guides the insect and fosters the parasitic regetable, to lodge wherever a plant lies prostrate, and aid atmospheric influences in affecting its conversion from noxious matter to living nutriment, was doubtless in operation from the first. Hence no structure could be preserved unless quickly enveloped in mud or silt, and no large collection of standing trees could be fossilized save by catastrophe. 
The fact of decayed vegetable tissue, ministering in so many forms to the sustenance of man, is a notable instance of the wisdom of God, though drawn from amidst the lowest of his lower works. In one form that of manure these products compose the industrial wealth of agriculture; in another, that of coal, they constitute the foundations of commercial enterprise. How skilful and wonderful are all his works, who "doeth all things well !"

"Thou everywhere hast sway, And all things serve thy might;

Thy every act pure blessing is, Thy path unsullied light!" 
SUPERFICIAL DEPOSITS.

Reasons for Separate Treatment. Effects of Causes now in Operation. Peat Bogs. White of Selborne. Evelyn. Tin Deposits of Cornwall. Ireland. Submarine Forests on Coasts of Normandy, Cornwall, and elsewhere. Connection between these Deposits and Extinct Races of Animals.

"To Thee, whose temple is all space,

Whose altar, earth, sea, skies ;

One chorus let all beings raise,

All nature's incense rise."

IN the foregoing account we have omitted all mention of the fossils found in superficial deposits. The epithets "fossil" and "geological" are frequently restricted to discoveries in the solid strata of the earth, exclusive of the covering of vegetable mould and alluvial beds. But in order to understand the value and nature of the 
evidence upon more ancient portions of the globe, it will be useful before adverting to them, to describe separately such phenomena as may have occurred during the period to which secular history relates.

In our own country we have some operations now slowly going on analogous to former geological movements. The formation of peat bogs; the filling up of lakes, rivers and estuaries; the scooping out of new channels by streams; gradually alter in some places the character of existing vegetation, although the relative levels of land and water may remain the same.

The valleys and fens of Britain from Caithness to Cornwall, contain the remains of forests; and what is worthy of remark, the trees are found rooted in situations where now sterility reigns.

In White's history of Selborne, he states that in Walmer forest are many bogs which formerly abounded with subterraneous trees, of oak, willow, and alder, which the cottagers commonly used. He adds that one of the peat-cutters had just sent to a carpenter in the village the butt-end of a 
small oak, which had apparently been severed from the ground by an axe, was ponderous and black as ebony.

The quaint Evelyn says, "That incomparable Naturalist, the learned Dr. Merrett, in his Pinax, speaks of several places of this nation where subterraneous trees are found, as namely in Cornwall, Flints, Pembrokeshire, Cheshire, Cumberland, Anglesea, and several of our Euro-boreal tracts, and are called Noah's ark. By Chatnesse, in Lancashire, (says Camden,) the low mossy ground was no very long time since carried away by an impetuous flood, and in that place now lies a low irriguous vale, where many prostrate trees have been digged out, these trees were some think carried away in times past by some accident of inundation, or by waters undermining the ground, till their own weight and the wind's bowed them down, and overwhelmed them in the mud: for 'tis observed that these trees are nowhere found but in boggy places; but that the burning of these trees so very bright, should be an argument they were fir, is not necessary, since the bituminous quality of such earth 
may have imparted it to them, and Camden denies them to be fir trees, suggesting the querie, whether there may not possibly grow trees even under the ground, as well as other things. There are in Cumberland, on the sea-shore, trees sometimes discovered at low water and at other times, that lay buried in the sand; and in other mossy places of that shire 'tis reported the people frequently dig up the bodies of vast trees without boughs, and that by direction of the dew alone in summer, for they observe it never lies upon that part under which those trees are interr'd."**

In Cornwall the valleys in and around the granite districts, have been carefully examined for tin pebbles in the process called tin streaming. In these lonely barren regions the delicate pink heath, (erica tetralix) now springs up amidst the mosses, the fairest and largest representative of the vegetable kingdom; but the traveller who pauses to watch the primitive-looking miners in the stream work, may perceive by the side of their excavation, 
a heap of dark wood, and on examining the pit he will see a layer of leaves and woody matter upon the tin gravel. The history of these deposits has been fully investigated: a common section is (1) the surface mass of peat, ( 2 ) a bed of gravel, ( 3 ) a layer of river sand with trees, the remains of red deer, and the works of man, (4) another bed of sand, and then of mud, with hazel nuts, wood, and moss; and below this, the roots of trees amidst the granite and tin pebbles which lie on the rocky floor. There are usually two layers of vegetable matter, but only one of roots. The remains of animals and the works of man are found in both, but the latter do not conclusively prove that man inhabited these once sylvan shades, as they may be due to the works of ancient miners. The trees are such as grow in lower valleys of the same districts at present.

Ireland abounds in bog timber, which is there clearly associated with the Elk, and with traces of man's occupation. In the Penny Cyclopedia we read that in June, 1833, an antient wooden house was discovered in Drumkelin bog, in the parish of Invernon, 
near the north coast of the county of Donegal, in Ireland, by James Kilpatrick, while he was searching for bog timber. The roof of the house was four feet below the surface of the bog, but estimated to have been sixteen feet below the surface before any peat had been removed. The framework of the house was very firmly put together without any iron: the roof was flat and made of thick oak planks, it was twelve feet square and nine high. The hut consisted of two floors, each about four feet high ; one side of the house was entirely open. A stone chisel was found on the floor. A pathway was traced for several yards leading to a hearthstone, which was covered with ashes, and near it were several bushels of half burnt charcoal with nut shells and blocks of wood. On the same level as the foundation of the house, stumps of oak trees were found standing, and beneath this a layer of sand and then another thick bed of peat.* Such discoveries of wood are common in the bogs of northern Europe, and recal a 
picture of extensive contemporaneous forests and marshes; fitting landscape for the barbarians whom at the dawn of modern history we discern wandering amidst the milderness.

The degenerate condition of our furefathers, the occupants of these gloomy wilds, serves to remind us of the calamitous condition of those who are destitute of the light of Divine Revelation; and by parity of reasoning, also convinces us of the moral degradation which must ensue from the neglect of this the only source of true civilization and advancement.

Another class of phenomena affords unequivocal evidence of change in the sea-level. The raised beaches, which are common along our shores, and the submarine forests which also fringe many portions of the same, attest two opposite instances, of this our task requires some allusion to the latter.

The submerged forests on the shores of Normandy and Cornwall, have been the subjects both of tradition and legend.

The Cornish tradition is that the space between Mount's Bay and the Scilly Islands, 
was once covered by a dense forest, in which the present St. Michael's Mount arose, as a hill in a wilderness of wood.

The Norman legend is, that in the year \%09, a low wooded tract of six miles breadth was suddenly submerged, leaving the once forest-girt Mount St. Michael a rocky islet.

In aid of the popular belief, relative to the subsistence within the historical era of a large space of land off our western shores; we have, first, the undoubted fact, of the remains of trees, imbedded in the soil, with their roots extended as when growing, visible below the present sea level, on the northern shores of Brittany and Normandy, the coasts of the channel islands, and the promontory of Cornwall. 2ndly. The fresh appearance of these remains, still convertible to economical uses, and in many places actually so converted. 3rdly. The occurrence of fragments of tiles, and other indications of human works, amidst the soil of the forest. 4thly. The peculiar aspect of some half-tide rocks within the area of subsidence. 5thly. The specific legends agreeing with observation of physical facts . 
Such deductions should render us grateful that no similar wide devastations have been permitted in our day; and when we reflect on the desolation which a trifling alteration in the sea level would produce, we shall feel anew our entire dependence for existence on Him who "holdeth the waters in the hollow of his hand."

Nearly a century since the following account of a submarine forest was published by Dr. Borlase.

" On the strand of Mount's Bay, midway betwixt the piers of St. Michael's Mount and Penzance, on the 10th of January, 1757 , the remains of the wood which according to tradition, covered anciently a large tract of ground on the edge of Mount's Bay appeared. The sands had been drawn off from the shore by a violent sea, and had left several places, twenty yards long and ten wide, washed bare, strewed with stones like a broken causeway, and wrought into hollows somewhat below the rest of the sands. This gave me an opportunity of examining the following parts of the ancient trees; in the first pool part of the 
trunk appeared, and the whole course of the roots eighteen feet long and twelve wide, was displayed in a horizontal position; upon spading round we found the sand to be a thin layer only of ten inches deep, and then the natural earth appeared in which the roots remained so firmly fixed, that with a pick and crow of iron, we could not get off one piece, but were content to saw off what we could come at. The trunk at the fracture was ragged and by the level range of the roots which lay round it was part of the body of the tree just above its division into roots. Of what kind it was there did not enough remain above the roots positively to determine. The roots were pierced plentifully by the teredo or auger worm. Thirty feet to the west we found the remains of another tree; the ramifications extended ten feet by six; there was no stock in the middle; it was therefore part of the under or bottom roots of the tree, pierced also by the teredo, and of the same texture as the first. Fifty feet to the north of the first tree we found part of a large oak; it was the body of a tree three feet in diameter; 
its top reclined to the east. In this much more solid wood the teredo had made no lodgments; we traced the body of this tree as it lay shelving, the length of seven feet, but to what further depth the body reached we could not discern, because of the immediate influx of water, as soon as we had mad a pit for discovery. The earth reached within six inches of the surface of the sands; but so firmly rooted was the tree that no sledge could move it: not so fixed was the stock of a willow tree, with the bark on, one foot and a half diameter, within two paces of the oak, where, upon endeavouring to cleave off a part of the willow, the earth shook so much under the people at work, they were in some doubt whether they had best proceed: the timber of the willow was changed into a ruddy colour by lying so long in salt water. Hard by we found part of a hazel branch, with its fat glossy bark on. The earth in all the tried places, appeared to be a black, cold, marsh, earth, covered only with a thin layer of sand, but very little intermixed. In it we find fragments of the leaves of the Juncus 
aquaticus maximus; and had any flowers appeared, they would have pointed out the season of the year when all these, vegetables were interred, but I could find none.

"The place where I found these trees was three hundred yards below full-sea mark; the water is twelve feet deep upon them when the tide is in."**

On the north coast of Cornwall we were surprised to perceive that the rough ground sea had laid bare an area usually concealed by the sand, but now covered with a black peaty substance which on inspection proved to be the branches, trunks, and roots of forest trees. The latter by the manner in which they were inserted in the soil shewing that their home had been there. It was in a small sandy bay, no tree can struggle into vigorous life within half a mile of the bleak cliffs at present, and yet here had once been a thick wood. The substance of the timber shewed the same structure as the ordinary indigenous wood of the country. Bones of the stag and of horned cattle were 
found imbedded. These appearances are frequent round the shores of Cornwall and Devonshire, the coasts of Great Britain and France. The remains are very extensive and of common occurrence. The wood is oak, elm, alder, pine, and hazel, besides underwood and mosses. The numerous instances enable us to affirm with certainty as a general position, that in northern Europe the land now beneath the sea level in coves, creeks, and bays, has formerly sustained a vegetation similar to that which now clothes adjacent woodlands, and that this land has been depressed beneath the waves of the present ocean. The occurrence of raised beaches at different heights along the same shores, also proves the elevation at other times of the same so-called terra firma. In the hollow of the cliff above may be discerned a line of beach, the token of one former level, and deep in the sands beneath may be uncovered the traces of another. The really constant stable element in reference to its position, is probably the sea and not the land. 
"Time writes no wrinkles on thine azure brow, Such as creation's dawn beheld thou rollest now !"

In investigating the remains of gravel deposits, and of some dried up lakes, it is difficult to separate them in some instances from the tertiary beds belonging to the geology of a previous era. An examination of the fauna of these deposits is more decisive of their true position, than an inspection of their flora; but our limits do not permit us to describe the occupants of the plains and forests at the morning of the historical era.

In Europe the great Elk, the aurochs, the red deer, the wolf, succeed to an empire once owned by the cavern-bear; the elephant, rhinoceros, hyena, and their congeners, during the epoch of caves: between the two dynasties a vast drift from the north, probably accompanied by floating ice and glaciers, devastated the surface and entombed the former inhabitants. The remains of man and his works confer a mysterious interest on the forests which appear to have been contemporary with his early appearance here. Our rude fore- 
fathers, in the scanty furniture and precarious subsistence of savage life, rise upon the view; the scooped canoe, the flimsy coracle, the hut, the weapon, tell us of their life; and they are thus linked to the extinct organisms of the past. The cavern animals of former races are connected in local associations with their successors, the cavern dwellers of the present race. Though very many centuries probably elapsed between the disappearance of the elephant and the appearance of man on the banks of the Thames, yet this is not a wider interval than is indicated by a hundred previous breaks in the chain of organic life.

The new fact, however-the appearance of man-is one of which all investigation of previous phenomena had premonished us by faint shadows. We see the result, and are permitted to trace some features of the plan. The creation of man was not merely one event of a long series of developements, but a grand special occurrence to which all these phenomena were made subservient. 
Another vast break occurs between the creation of the present order of things, and the appearance in these western parts of the dweller in the hut now imbedded in the peat. The chasm thus found is as to man's portion of the history filled up by a dismal tale of sin, woe, and degeneracy.

For us there remains the due expression of gratitude that our lot is placed neither amidst the dark places of the earth, nor in its darker epochs. 


\section{CHAPTER V.}

FLORA OF TERTIARY AND SECONDARY ROCKS.

Plan of Investigation. London Clay. Sheppey Fruits. South American Fossil Forests. Amber. Flora of the Chalk and Greensand. Oolites. Portland Quarries and their Cycadean Remains. New Red Sandstone.

\section{"Oh there is not lost}

One of earth's charms : upon her bosom yet After the flight of untold centuries, The freshness of her far beginuing lies, And yet shall lie."

We have next to enter upon the investigation of those strata which are beneath the accumulations now in course of formation.

The surface of the earth derives its present fitness and beauty, not so much from the quantity or richness of its vegetable soil, as from the distribution and character of the subjacent strata. If the 
materials of the latter had been either confusedly mixed, or arranged in accordance with relative density, or in horizontal layers, the result would have been a monotony of aspect very different from the diversified landscapes which now adorn all portions of the globe. The present arrangement is the result of successive layers of different material, not all co-extensive in surface, nor equal in depth, subjected since deposition to violent fractures and disturbances produced through the agency of matter which has been added to the mass in the shape of crystalline rocks.

The surface area of each formation in England is remarkably small; we thus possess in our own country a miniature edition of the world's geology.

The antiquity of the exposed strata, as indicated by their relative position, increases in Great Britain from east to west. The Imountains of the western Highlands of Scotland, of Cumberland, Wales, and Cornwall, rise apparently from beneath successive waves of sedimentary matter, each falling 
short of the point reached by its predecessor.

It will be convenient therefore to consider the formations in the actual order of their occurrence at the surface, and we may do this with sufficient completeness by assuming that our student commences his journey at the metropolis, and shapes his course westward in search of primary rocks.

1. Tertiary deposits. The first portion of his travels lie over the tertiary strata.

This name was given to the collection of sands and clays which form the centre of France, and the subsoil of the London district, to distinguish it as the third term in the supposed upward process from the primitive to the present; it is still retained as a convenient appellation for the groupe which has since received the more significant names of Eocene, Miocene, and Pleiocene.

One of the mounds arising from a street excavation in the metropolis, so obstructive to all save the geological passenger, may supply the latter with materials for beginning his collection of facts. 
The blue clay underneath the gravel contains many shells, telling of the ocean which once rolled where now the tide of human life continually flows. It occupies an extensive area in Middlesex, and in Hampshire, and affords evidences in several places of the islands and shores of that ancient sea in the depths of which it was tranquilly deposited.

Fragments of wood, water-worn and piereed by the worm, are sometimes discovered in the district, and the resinous products of the fir forests of a former age, have also been found in considerable quantities.

In Sheppey, at the mouth of the river Thames, the clay is abundantly fossiliferous, yielding the remains of numerous fruits and flowers. These bear much resemblance to the productions of the tropics, but are not absolutely identified with any species in actual present existence.

"The first tertiary land concerning which we have distinct knowledge, was richly clothed by a vegetation, a good deal of whose general character is recognised by 
examining the fruits of trees and fragments of wood found abundantly in the Isle of Sheppey. These fossils are exceedingly numerous and varied, and the fruits obtained from the single locality just alluded to, include several hundred species, all of which are different from existing and known plants, although many of them seem closely allied to generic forms now met with in warmer climates than those at present characterising similar latitudes. There is indeed, nothing in these plants which removes them at once and in a marked manner from the existing type; and the most remarkable fact concerning them as a group is the preponderance of species allied to the palms, some of them being apparently intermediate between the cocoa-nut and the pandanus, or screw pine well known, and common tropical plants not met with now in northern latitudes. The recent analogies of another genus the family of Nipæ, inhabit the Spice Islands and Japan, and chiefly in low damp or marshy tracts, at the mouths of great rivers, especially in brackish water. Associated with these are some varieties of 
the cucumber or gourd tribe, the pod of a variety of acacia or mimosa, the seeds of cyprus-like plants, and the fruits of some coniferous trees. There are also fragments of wood and stems indicating the presence of a species of the pepper plant, of several varieties of palm trees, and of several coniferous trees."*

Such descriptions savour more of the poet's pictures, than of the sober narrative of the naturalist.

"Is it where the feathery palm-trees rise, And the date grows ripe under sunny skies? Or, 'midst the green islands of glittering seas, Where fragrant forests perfume the breeze; And strange bright birds, on their starry wings, Bear the rich hues of all glorious things ?"

"Not there, not there, my child."

In Northern Europe the tertiary deposits are usually accompanied by subordinate beds of fossil wood. The nature of the contemporaneous animal remains, proves that in some instances these accumulations took place in a marsh or fresh water lake,

* Ansted's Ancient World, 269. 
in others in an estuary, in the greater number in the ocean bed. There have been periods during which the sea and the lake have had alternate prevalence in some localities, as in central France. In Southern Europe, in Asia, in South America and elsewhere, the tertiary formations exist in a more solidified form, as rocks of imposing magnitude.

As a fitting accompaniment to $\mathrm{Mr}$. Ansted's picture of the groves which at this era adorned the eastern shores of our own island, we extract from Darwin's Journal his account of the petrified forest found amidst the volcanoes of the Cordilleras in South America.

"The Uspallata range is separated from the main Cordillera by a long narrow plain or basin, like those so often mentioned in Chili but higher, being six thousand feet above the sea. This range has nearly the same geographical position with respect to the Cordillera, which the gigantic Portillo line has, but it is of a totally different origin; it consists of various kinds of submarine lava, alternating with volcanic sand- 
stones and other remarkable sedimentary deposits; the whole having a very close resemblance to some of the tertiary beds on the shores of the Pacific. From this resemblance I expected to find silicified wood which is generally characteristic of these formations. I was gratified in a very extraordinary manner. In the central part of the range, at an elevation of about seven thousand feet, I observed on a bare slope some snow-white projecting columns. These were petrified trees eleven being silicified, and from thirty to forty converted into coarsely crystallized white calcareous spar. They were abruptly broken off, the upright stumps projecting a few feet above the ground. The trunks measured from three to five feet each in circumference. They stood a little way apart from each other, but the whole formed one group. Mr. Robert Brown has been kind enough to examine the wood: he says it belongs to the fir tribe, partaking of the character of the araucarian family, but with some curious points of affinity with the yew. The volcanic sandstone in which the trees were 
imbedded, and from the lower part of which they must have sprung, had accumulated in successive thin layers around their trunks; and the stone yet retained the impression of the bark.

"It required little geological practice to interpret the marvellous story which this scene at once unfolded, though I confess I was at first so much astonished, that I could scarcely believe the plainest evidence. I saw the spot where a cluster of fine trees once waved their branches on the shores of the Atlantic, when that ocean (now driven back 700 miles, ) came to the foot of the Andes. I saw that they had sprung from a volcanic soil which had been raised above the level of the sea, and that subsequently this dry land, with its upright trees, had been let down into the depths of the ocean. In these depths the formerly dry land was covered by sedimentary beds, and these again by enormous streams of submarine lava, one such mass attaining the thickness of a thousand feet; and deluges of molten stone and aqueous deposits five times alternately had been spread out. The ocean 
which received such thick masses must have been profoundly deep; but again the subterranean forces exerted themselves, and I now beheld the bed of that ocean, forming a chain of mountains more than seven thousand feet in height. Nor had these antagonist forces been dormant, which are always at work, wearing down the surface of the land. Now all is utterly irreclaimable and desert; even the lichen cannot adhere to the stony casts of former trees."**

There are some fragments of the former history of the northern seas beautifully preserved embalmed in amber.

Wave-worn pieces of this resinous substance are so numerous along the southern shores of the Baltic, as to form an important article of commerce, and to denote that immense forests must have existed on the land now forming the bosom of that sea.

Amber is the resin of a fir tree, probably of one species alone, and that one now extinct, the Pinus succinifer. The foreign organic substances which it contains have

* Darwin's Journal of Beagle Voyage, Chap. xv. 
been minutely investimated, and the research has been rewarded by the discovery of no less than eight hundred distinct species of insects, from the beetle to the dragon-fly. Spiders, whose representatives now live in the trunks and amidst the roots of trees, are also found thus delicately preserved; nor does the vegetable kingaiom lack subjects in this fragrant museum, for the rood of the beech, ash, fir, poplar, pine, cypress, juniper, and other trees, has been recognized; besides leaves of heath, ferns, and mosses.

The flora of the amber consists of upwards of forty-eight species, none of which are identical with species of similar plants now growing on the neighbouring land; though this flora does bear a northern character, and as a groupe is similar to that of the fir forests of Canada.

The gum of the amber-fir must have been exceedingly abundant; but allowing for the greatest imaginable excess of this substance, yet the forests whose gems have been thus thrown up by the waves of many successive centuries in undiminished quantities, 
must have been of prodigious extent; and the inquiry is naturally suggested, what has become of the submerged trunks? have they yielded to total decay, or are they undergoing mineralization for future use?

There is no similarity between the productions of the amber and those of the coal measures, now existing in the same latitudes. A vast amount of change had passed upon the earth between the two periods.

These crystal vases, thus holding in imperishable perfection the delicate organization of plants long since passed from the stage of life, are the depositaries of historic fragments of extinct races. The record testifies concerning them, that they were planned by the same Artificer, and were constructed on the same general rules, as their representatives of the present day.

The whole of the strata superior to the chalk disclose local deposits, varying in the kinds of animals and plants found in them. In some places successive series of such beds shew the long continued action of geological changes. The climate, and the range of animal and vegetable life, though different 
from the existing state of things, are yet far nearer to present conditions than the more uniform vegetation and high temperature of the carboniferous era. The palm groves of the tertiary yield to their successors the pines of the peat-moss, as the tapir gives way to the ox; and the low hills of the Pleiocene are succeeded by lower alluvial plains.

The strata now under consideration, by their disposition and contents, exhibit just so much similarity to the present order of things, as entitles them to the character of heralds of the approach of man, the delegated monarch of this lower world. They shew the preparations of the theatre, the arrangement of the instruments, which ought to have been by him at once and for ever made resonant with the Creator's praise.

The seeds of the argument for design are sown as deep as our researches have penetrated: like the indigenous florfers which spring up from long buried soil, the proofs of divine plan and purpose arise and grow wherever the student explores the depths of the material universe. 
"Can we glance over the earth, and into the wilderness of worlds in infinite space, without being impressed with the solemn thought that all this is but the sign and proof of something infinitely more glorious than itself? Are we not reminded, this is a production of his Almighty power; that is an adjustment of his all-comprehending intelligence and foresight; there is a glimmer, a ray of his beauty, his glory; there an emanation of his benignity; and there some fiery trace of his justice; but for him all this would never have been; and if for a moment his pervading energy were by his will restrained or suspended, what would it all be then? not to have some such perceptions and thoughts, accompanied by devout sentiment is so far to be "without God in the world." And that there should be men who can survey the creation with a scientific enlargement of intelligence, and then say "there is no God," is one of the most hideous phenomena in the world."*

* Foster's Lcctures, Second Series, 282. 
2. The Chalk.-The traveller from London in any direction will find after passing the deep clays of the first cuttings on his road, a more open hilly district, sections in which display the dazzling whiteness of the chalk. The lower beds of this are sandy, and rest on an associated deposit called greensand. A few sea weeds and some portions of drift wood, yield all the knowledge we obtain from the pure chalk, as to the state of contemporary vegetation. Nearly all its organisms indicate a deep sea with few islands. The lower sandy beds are, however, rich in accumulations of drift wood and sea-weed, with local deposits of plants, among which stems of Dracrna, cones, and fruits indicate the existence of pine and palm woods.

3. The Wealden.-Our geological traveller will find on arriving at Swindon a narrow fossiliferous bed, which is the prolongation of deposits more largely developed in the South Eastern counties, consisting of dark clays and sands usually crowned with oak foliage, and bearing internal tokens of having been formed at the mouth of some vast 
estuary. The Wealden is a series of local beds, and in a general account of geological periods it may be ranked with those next to be considered.

These strata have their characteristic flora, but they do not offer to the botanist any of the wonders which the iguanodon and gigantic lizards of this formation display to the Zoologist.

"On rifted rocks the dragon's late abodes, The green reed trembles, and the bulrush nods.

Waste sandy valleys, once perplex'd with thorn, The spiry fir and shapely box adorn:

To leafless shrubs the flowery palms succeed, And odorous myrtle to the noisome weed."

4. Oolite and Lias.-Before arriving at Bath, an improvement in architecture will be manifested in the appearance of the stone buildings which succeed to the brick erections of the clay and chalk country. The yellow Oolite rocks, and the blue Lias beneath them, are associated in a band running from Devonshire to the eastern coast of Yorkshire, the Lias being the lowest and westernmost. 
The biue Lias has strange revelations to make of marvellous animal remains, outrivalling all the dragons and centaurs of fable; the Oolite too is so crowded with ocean shells, that many of its layers are like the drawers of a rich well-arranged cabinet. Their vegetation includes both aquatic and terrestrial plants, corresponding to a fauna, which includes the nautilus, the saurian, and the opossum. The harmless newt of our ditches hardly differs more from the sharklike crocodile of the Lias, than the species of vegetation now trimly adorning the surface from that which the quarries lay bare. Were it not that in this and in all our researches into the former condition of the earth, we are met by overwhelming proofs of the perfect adaptation of created things to each other, and to their locality, and of an exact optimism in their actual structure, we might dream of the fables of eastern mythology, and imagine a change in the govermment of the universe; but fossil geology is of all other sciences the best able to assure us of the constancy of God in his works, and thus to afford us a world-wide foundation for 
belief in the promises and threatenings of his word.

The upper members of the Oolitic series, appear to be the Portland beds, which are irregularly dispersed, and not so extensive as the subsequent class. On drawing away the incumbent rock, to get at the building stone of the Island of Portland, a remarkable scene is disclosed. The layer of stone now so profitably wrought, appears to have been surmounted by an ancient vegetable soil, in and upon which are a great number of silicified trunks of coniferous trees and plants of the Cycadian and Zamian genera.

The stems of many of the trees are erect, the roots strike into the soil which is accumulated round their bases, and their trunks extend into the superincumbent limestone. Between the larger trees the Cycadeæ are found evidently in the place where they grew. Here there is an unequivocal instance of the former existence of a tropical forest, growing in the place where the scantiest shrub now hardly flourishes in the soil immediately above. The facts are for ever decisive against all reasoning on the hypo- 
thesis of the transportation of the rernains from equatorial regions. We can allege, with all the verity that belongs to the best proved history, that the upper beds of the Oolite in the South of England, sustained a lofty vegetation, and that the land crowned with its leafy honours descended into the bosom of a deep and tranquil lake, whose bed it formed for many succeeding ages, in the course of which calcareous sands and clay were thrown down, mixed with the remains of lake and estuary amimals. This condition of things must have lasted some time as is evidenced by the vegetation of the Wealden, and must have been succeeded by another great change in the sea level, by which the ocean again resumed the place it had occupied in the Oolitic age, but with more uniformity and probably a greater depth. From this sea resulted the thick mantle of green sand and chalk which now overlaps the former deposits in the South West of England.

The more solid beds of the Oolite hardly exhibit any trace of vegetation.

A sort of shale composing the famous 
Stonesfield and Solenhofen deposits, as well as that of Mamers in France, throw the chief light by its contents on the plants of this period; as the circumstances of deposit in these instances have been evidently very favourable to the preservation of organic structure.

At the two former places are found seaweed, which accords with the neighbouring incontestible evidence of coral reefs, to shew the existence of the ancient seas of these their tropical islands, for even the sea weed is of an equatorial character. Several ferns too occur in the same locality, but the predominant race is that of the Cycadeæ. These palmy and tropical plants which now form so very inconsiderable a portion of the existing vegetation, (not perhaps equalling a thousandth part of it, ) in the days of the Oolite deposit constituted more than half of the entire vegetable kingdom. At Stonesfield, in the dried mud of the Oolite deposit, are also found remains of several species of unknown cone-bearing plants.

The lowest members of the series appear to be Lias and Lias Marl. In this deposit 
we find specimens of the equisetum of a height now only attained in the marshes of equatorial regions.

The columnar equisetum is found vertical at Whitby, and in a position which evinces that it grew where we now find its remains.

Several species of ferns have been discovered in this deposit at Hör, in Sweden, and near Basle, attesting the existence of dry land in those places during the Liassic era.

5. New Red Sandstone.-Below the Oolite, the wayfarer will encounter a series of marls and variegated sandstone, including the great salt deposits, and comprising many members more fully developed on the Continent than in England.

Some cypress-like trees, gigantic calamites, several ferns, all differing specifically from those on either side, are enumerated from these rocks. 'The absolute want of identity between the vegetables of different series of rocks is well ascertained, and prepares us to find their total unconformity with present foliage. The boundless variety 
of the works of creation, bespeaking the infinity of the resources of the Creator, is well displayed even in the limited discoveries of fossil botany.

"So reads he nature whom the lamp of truth Illuminates: Thy lamp, mysterious Word ! Which whoso sees no longer wanders lost, With intellects bemazed in endless doubt, But runs the road to wisdom." 


\section{CHAPTER VI.}

COAL FORMATIONS.

Vegetation of the Coal bearing Strata. Enumeration of Families of Plants found Fossil. Remarks on the Seanty Number of Genera. Difference of Aspect and Character from the fiora now around us. Facts and conelusions as to mode of Deposit. Roots of Trees and Upright Stems. Various Instances. Coal of other formations.

"Let everlasting thanks be thine, For such a bright display ;

As makes a world of darkness shine,

With beams of heavenly day."-Coupper.

THоse persons who find entertainment in recalling the carly stages of their mental progress, will remember the difficulty with which they embraced the idea that limestone is made up of sea shells, and coal of petrificd vegetables. They may find an apology for their prejudices in the history of geology, 
in whose infancy and youth both these positions were subjects of frequent controversy by learned men.

In order to unravel the story of the coal deposits, we must advert to the associated rocks; the subject, like a contested passage in an ancient author, requires the aid of the context to render it intelligible.

The dark hard mountain limestone, or some inferior rock, supports a series of numerous beds of sandstone and clay interstratified with layers of coal.

The sandstones are the consolidated fragments of other previously existing rocks; the clays and shales are finer accumulations of similar materials; the whole evidencing a mechanical deposit from water. The contained layers of carbonaceous matter are mineralized in their structure, and were long supposed to be of mineral origin, but the frequent occurrence of fossil vegetables in various states of preservation, and the investigations both of botanical and chemical observers, have rendered their vegetable derivation an unquestionable conclusion.

The distinct plants found in the coal are, 
I. The bamboo-like Calamites, abundant equally in the collieries of our own island, Germany, Bohemia, Belgium, France, Virginia, Pensylvania, and Nova Scotia, and of which identical species are found at all these places.

The Calamites Suckowii has now its tomb where it had once its dwelling, at Newcastle, Saarbruck, Anzin and Litry, on the old continent, and at Wilkesbarre and Richmond, in the United States.

II. The Ferns, of which there are upwards of 150 species found in these dark caverns, many of which have a range wide as the calamites, and one or two extend still further, and appear in New South Wales and in India.

Sphenopteris Trifoliata extends from Silesia to Yorkshire.

Several species of Neuropteris have an American as well as a European locality, and so of Pecopteris: whilst one remarkable fossil, Glossopteris Browniana, has been found in mines on the Hawkesbury River in Australia and Rana Gunge in India.

The arborescent ferns now known, all 
require a high temperature, and yet the coal of Melville Island in the Polar regions, contains fragments of these remarkable fossils.

III. The Marsiliacia, altogether peculiar to this formation, and also common in it to both continents. These small plants with their whorls of star-like leaves, look like delicate drawings made with varnished ink on the surfaces of the coal shale.

IV. We may also enumerate decided coniferous trees in the coal strata, some palms and canes, the gigantic Lepidodendron and Sigillaria, with other forms elsewhere referred to.

It is therefure established that the northern latitudes once displayed $x$ vegetation composed of species, the representatives of which we now nurse as exotics in hothouses; and that too by heat produced from the combustion of their remote predecessors which grew unsheltered in the same spot. So passing strange is the system of adaptations and conversion exhibited in creation.

The following tabular view of the vegeK 5 
table fossils of the coal measures is extracted from the able outline of our science published by Monsieur Adolphe Brongniart in 1828.* Subsequent researches have added to the lists and have made the important alteration of placing some dicotyledonous species of timber trees within the ranks of the coal plants. Brongniart adds, "A glance at this table will suffice to shew the difference which exists between the vegetation of the era referred to and that which now covers the globe. The greatest part of this flora is formed of vascular cryptogamia, that is to say Ferns and their allied families, which constitute by themselves five sixths of the sum total of the plants of this period, whilst they form but one thirtieth of actual vegetation; on the contrary dicotyledonous plants, which compose more than three fifths of living vegetables, probably did not exist at all at this epoch, or formed but one twelfth of its vegetation, supposing that we place in this class the twenty species the place of which is uncertain."

* Prodrome d'une histoire des Vegetaux Fossiles. 


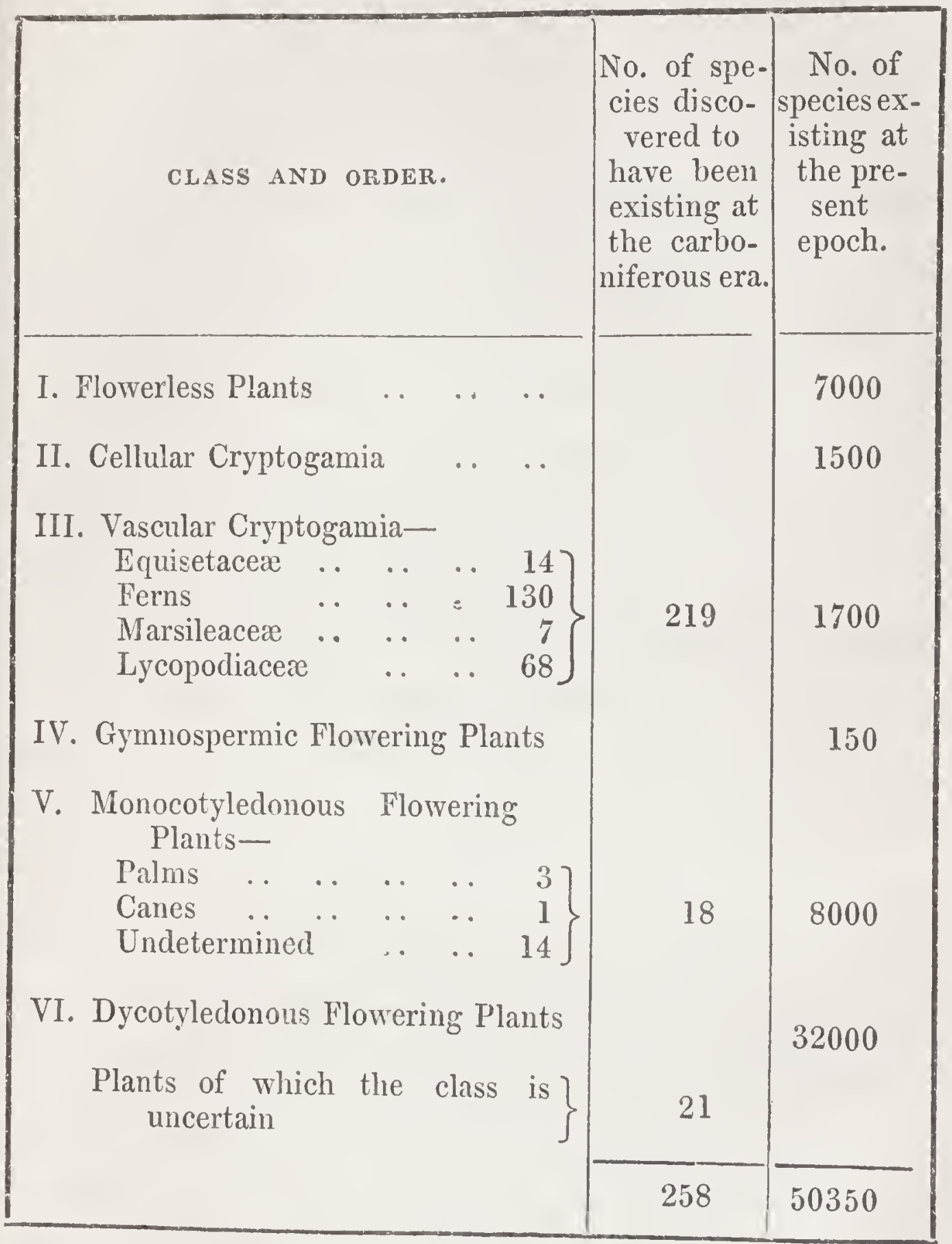

Messieurs Lindley and Hutton in their great work, so full of exquisite illustrations of extinct vegetation, thus sum up the evidence as to the carboniferous period. 
"It would hardly be credited by persons unacquainted with the evidence upon which such facts repose, that in the most dreary and desolate northern regions of the present day, there once flourished groves of tropical plants, of Coniferæ, like the Norfolk Island and Araucarian Pines, of Bananas, Tree-ferns, huge Cacti, and Palms; that the marshes were filled with rush-like plants fifteen or twenty feet high, the coverts with ferns like the undergrowth of a West Indian Island. Yet nothing can well be more certain than that such a description is far from being overcharged. In the coal formation, which may be considered the earliest in which the remains of land plants have been discovered, the flora of England consisted of ferns in amazing abundance, of large Coniferous trees, of species resembling Lycopodiaceæ, but of most gigantic dimensions, of vast quantities of a tribe apparently analogous to Cactae or Euphorbiacere. but, perhaps, not identical with them, of Palms, and other Monocotyledones; and, finally, of numerous plants, the exact nature of which is as yet extremely doubtful. Be- 
tween two and three hundred species have been detected in this formation, of which two thirds are ferns." *

This catalogue exhibits but a short roll of family names, and yet it may be presumed to include the bulk of the vegetation existing at the epoch when these materials were deposited. The results shew that the actual amount of vegetable life during the successive periods of this era, must have been enormous to our apprehensions, as compared even with the tangled forests of low tropical islands of the present earth. Monotony of form must then have obtained so as greatly to deprive the landscape of the charming variety of colour and outline, which now enriches and adorns the earth.

Another and more important variation between past and present is found in the extent of surface over which a particular race of plants is spread.

The ferns, for instance, though some of the most widely scattered of existing plants, yet are not so widely distributed at present 
as they once were when their dark prototypes flourished.

If we follow the course of the mighty Mississippi, we shall sail down through foliage of ever varying character, from the slender leaf of the birch, to the noble crown of the palm; but we might mine into subterranean beds parallel to the whole of its long stream, and find no variance whatever in the fossil forms imprinted on their strata.

The fossil plants from Cape Breton coal field, are undistinguishable from those of our own collieries, and what is still more remarkable, identical also with those of Pennsylvania, Maryland, and Ohio; whilst the existing flora of all these countries differs as widely as their several climates. Even here, however, we find that existing analogies do not quite fail us, for whilst this remarkable uniformity extends unbroken over so vast an arca, yet the coal ficlds of the more southern region of Indiana do exhibit some variations from the northeru type, and those of New Holland present us with many forms altogether unknown in Europe.

The fossil remains usually occur in layers 
parallel to the original line of deposit or the bedding of the rock; they are also found inclined at all angles; and in numerous well attested instances have been discovered vertical, with their roots imbedded in the indurated mud beneath. The delicate markings of the Ferns, the flutings of the Calamites, the symmetrical markings of the Lepidodendron, all so nicely preserved, shew that their deposit was unaccompanied by great continued violence. Yet it must have been by catastrophe, for after allowing for the various rates at which plants macerated in water decay, we cannot reconcile the facts to the tranquil gradual subsidence of a forest into a lake, or its tardy conversion into a peat bog. We find a coarse muddy deposit, containing shells of freshwater mollusks, then a layer of coal plants and coal; over this a bed of sandstone; another layer of coal; another stratum of mud with shells; and so on for several successions; each of which requires time for its separate organisms to live, flourish, and become immensely numerous : each platform of life existing on the settled ruins of the 
preceding. No accumulations now in process of formation on this fair earth, afford adequate analogy to the steps of this mighty process.

The origin of coal is a much easier question to solve than the method in which it became placed where we now find it.

The prevalent suppositions are that it either resulted from a mass of vegetation matted together, and drifted down by a large stream, similar to the floating trees of the Mississippi ; or that it is the product of low luxuriant islands, which sank beneath the waters, and were covered with accumulations of mud and gravel. The latter hypothesis most nearly accords with the observed facts, as the plants are too perfect to admit of the former supposition, save in a few instances. But owing to the numerous beds of coal lying with intercalated sandstones and clays vertically above each other, the problem requires an amount of alternations of repose and submergence, baffling even the computation of the philosopher. An instance from one coal field, and that by no means the thickest, will illustrate 
this difficulty. Sir Charles Lyell, in his observations on Nova Scotia, says, that at a place called "The Joggins," there is a range of perpendicular cliffs on the coast, composed of regular coal measures, and including about nineteen beds of coal, all parallel, varying from two inches to four feet in thickness. At more than ten distinct levels in this series, there are stems of trees, each originating in a coal seam, all upright, with reference to the floor on which they grew, all cut off by the layers of mud and coal above. The trees were hollow, and the bark has become coal, the interior filled with sand. Here are then the unequivocal remains of ten distinct forests which grew at distant intervals on the same spot, and between the interval each in succession covered with clays and sands, which were deposited under water and have become solid stone. Such instances might be cited from nearly all the known deposits of coal; the latter evidently owing much of its present character to alternate changes of dry land and water: the ocean, or lake-bed, becoming a vegetable soil, sustaining its noble burden 
of foliage, sinking with it into the deep, the waters again resume their dominion, the marine creatures live, die, and are entombed,-

\footnotetext{
"And thy majestic groves of olden time

Perished with all their dwellers."
}

Then the platform is again raised, and the scene again slowly changed into the present appearance of things.

About ten years since in cutting through the rocks of the coal series for the Bolton Railway, six miles north of Manchester, five fossil trees were found in a position vertical to the plane of the strata. The roots were imbedded in soft clay immediately above a thin bed of coal. Near the foot of one tree lay more than a bushel of clay nodules. each enclosing a cone of Lepidostrobus variabilis. The bark of the tree was converted to coal, averaging half an inch in thickness, and the interior of the stem was replaced by shale. The largest trunk measured fifteen and a half feet at the base, seven and a half at the top, and the frag- 
ment was eleven feet high. One tree had large spreading roots four feet in circumference. By the care of Mr. Hawkshaw, these interesting remains are covered in and preserved on the spot where they were found.

Amongst many similar instances in which we obtain a peep into the glades of the most ancient forests, we will select one from the Welsh coal field, at Cwm Llech, near the head of the Swansea valley, where a ravine cuts into a group of Sigillariæ. At the foot of the trees coaly matter resembling roots is found, and the shale is full of fern leaves crossing each other in all directions, as if fallen and distributed on a muddy ground. "Studying the mode in which the sand was accumulated round the stems in order to trace if possible the direction in which the drift came against them, little was observed to mark an eddy caused by a rapid current upon them, at the same time the laminæ of the sandstone, were slightly raised towards the stems as if washed against them by small waves in shallow 
water. 'The largest stem was five feet six inches in circumference."

Besides trees thus found attached to roots, there are numerous cases of the occurrence of large trunks broken at each end, lying inclined in all directions in thick beds of sandstone; thus occurred the coniferous trees in Craigleith Quarry and New Haven near Edinburgh, telling us that they were uptorn from their native soil, and drifted by a muddy stream to their present resting place.

It would be easy to multiply to a great extent the relation of instances of the occurence of trees in the coal strata, apparently where they once grew. The following case occurs in the Staffordshire coal field: "At Parkfield Colliery one and a half miles west of Bilston, and at about the same distance south of Wolverhampton, there is a fine outcrop of this bottom Coal, which is now being got in open work; in one part the overlying fire-clay has been remored, and the surface of the coal exposed, over

* Memoirs of Ordinance Survey, Vol 1, p. 184. 
an area of a somewhat triangular shape, for about two thousand seven hundred square yards.

This terrace of coal exhibits on its surface one of the most remarkable accumulations of the fossil remains of the vegetation of the coal period ever exposed to view. There are upwards of seventy trunks of trees, apparently dicotyledonous, broken off close to the root, and several of them are more than eight feet in circumference : the prostrate trunks lying across each other in every direction. One of these measured thirty feet, another fifteen feet in length, and several others a few feet less. They are invariably flattened to the thickness of from one to two inches, yet both the upper and under side preserve a distinct trace of bark. The stumps also exhibit a distinct ring of bark, which as usual has become a bright coal, with a crystalline fracture: while the interior, or woody part, is a dead looking coal, nearly approaching to canal coal.

"These stumps seldom rise much above the surface. Many of them are surrounded by a circular ridge formed by the materials 
of the bed accumulating round them. In a few cases the place of a trunk is marked by a circular depression in the coal, the trunk having been probably removed with the overlying fire clay. In some of the stumps the thick diverging roots may be traced by clearing off the coal nearly a yard from the circle of bark."**

The beds of coal themselves, and those interstratified with them, vary horizontally in their contents; the coal sometimes thinning off, and being succeeded by sandstone or clay, and the reverse. The depth of the beds is also not constant, affording traces of the irregular action of floods. A stratum of fine mud, indicating a tranquil flow of fine sedimentary matter from a distance, preserving the delicate fern leaf in sharpness of outline equal to the living leaf of to-day, will be supplanted in another part by a confused mass of rolled pebbles, and crushed river shells. The extensive workings of these ancient flats and beaches, have disclosed their character as accurately as though they were but of yesterday,

* Journal of the Cicological Socicty, 1815, p. 13. 
instead of belonging to a period which no human eye witnessed, and no human hand recorded.

The alternations in the coal strata will be more easily understood from a statement of their actual contents, as they have been wrought for economical uses, and carefully described.

The following is from an elaborate memoir by Mr. Prestwich, on the geology of Coalbrook Dale, and embodies the result of very numerous observations made in all parts of that district.

I. Terrestrial strata, containing remains of land, plants, calamites and ferns.

II. Marine and Fluviatile. Shells of Leptæna, Conularia, and fragments of a fish Megalicthys.

III. Terrestrial and Fluviatile. Stems of Lepidodendron, fern leaves, shells of Unio an estuary creature.

IV. Marine and Fluviatile. Fishes and shells of Lingula.

V. Terrestrial. Coal with stems of Lepidodendron.

VI. Marine. Terrestrial and Fluviatile. Ironstone. Seashells. River shells and plants. 
VII. Terrestrial. Ferns and large plants. VIII. Fluviatile or Marine. Fishes, Megalicthys. Gyracanthus.

IX. Terrestrial. Fluviatile. Large plants. Unio.

X. Marine. Terrestrial. Fluviatile. Plants. Unios, Fishes, Trilobites.

XI. Terrestrial. Large plants.

XII. Marine or Fluviatile. Fishes. Unio. XIII. Terrestrial. Coal. Large plants.

XIV. Marine and Fluviatile. Ironstone Leptœna. Spirifer. Bellerophon Nautilus. Fishes.

XV. Terrestrial. Fluviatile. Large plants and trees. Sigillaria. Lepidodendron. Calamites. Ferns. Unios.

Base. Silurian Rocks.*

With such proofs of the existence and growth of large trees and plants, it is impossible to doubt the occurrence of rast forests common to both continents during the coal epoch, and in both composed of the same vegetation. The monotony of vegetable character is only the index to an uniformity of causes and of phenomena prevalent during that period, but entirely unknown

* Geol. Transactions, 2 d serics, rol 5, part 3. 
among the plants of the present world. They afford us a new illustration of the grandeur of the scale on which preparations were made for the great epoch, when "The Lord God formed man of the dust of the ground, and breathed into his nostrils the breath of life; and man became a living soul."**

"And surely it must be gratifying thus to see a science formerly classed, and not perhaps unjustly, among the most pernicious to faith, once more become her handmaid; to see her now, after so many years of wandering from theory to theory, or rather from vision to vision, return once more to the home where she was born, and to the altar at which she made her first simple offerings; no longer as she first went forth, a wilful, dreamy, empty-handed child, but with a matronly aignity, and a priest-like step, and a bosom full of well-earned gifts, to pile upon its sacred hearth" $q$

The conclusions to which we are led by

* Gen. ii. 7.

† Wiseman's Lectures on Science and Revealed Religion. 
the whole of this evidence are, First, That in most deposits of fossil plants some individuals grew on the spot where they are now found.

Second. That in many deposits there are accumulations of leaves, stems, and fruit and woody matter, the result of a long continuance of vegetation on the same bed.

Third. That in other deposits the materials have been transported by water, and are partly worn and decomposed.

Fourth. That in some places the sea, in others the mouths of rivers, rivers and lakes, have stood where the coal is now found; and elsewhere the ocean and the river, have successively alternated in occupation of the same ground.

Fifth. That the strata have been brought into their present position by riolent forces acting subsequently to their consolidation.

In the South Wales coal field are beds of fossil plants which contain coal pebbles also, proving that after the solidification of the lower coal, the action of rumning water formed gravel from its surface, which again served as soil for the growth of the plants, 
amidst whose remains these rolled stones occur. The irresistible conviction from such instances of the regular growth, decay, death, intombment, induration, elevation, erosion, and second deposit of these plants, is strengthened by the aspect of the whole; and extended by proofs of successive similar operations, to a period embarrassing to our contemplation as we measure the past by the present.

"One part, one little part, we dimly scan,

Thro' the dark medium of life's feverish dream,

Yet dare arraign the whole stupendous plan,

If but that little part incongruous seem;

Nor is that part perhaps what mortals deem,

Oft from apparent ill our blessings rise.

O then renounce that impious self-esteem,

That aims to trace the secrets of the skies,

For thou art but of dust, be humble and be wise."-Beattie.

The beds of coal exhibit on their upper surfaces proofs of the action of floods in scooping channels and hollows now filled up by the materials of the superincumbent strata. It is clear therefore that there must have been consolidation of the successive layers, and then violent streams breaking off fragments, forming pebbles, gravel and 
sand, and distributing these matters in water, and afterwards the bed thus formed was elevated, vegetation resumed its reign to perish as its preceding exhibitions had done in the same place.

A curious fact has been noticed respecting the base of the layers of coal; it was first remarked by Mr. Logan in the Welch Coal field, and is now regarded as established, namely, that the underlying stratum is almost invariably a clay containing Stigmaria, the presumed roots of the trees called Sigillaria. The clay bed varies in thickness from a few inches to ten feet, but is always found underneath the true coal, and contains these root-like plants and leaves. Long portions of root are connected with the main stem, and are thickly matted and entangled amidst the clay. In the recent memoir of the Ordnance Survey the facts are thus stated. "These underbeds are now known to be common in coal districts referrible to the Palæozoic series; we have observed them beneath all the true coal beds we have seen in Great Britain and Ireland. Mr. Logan notices them in Ayr- 
shire, and he detected thern in the United States under the coal seams of the anthracite regions of Pottsville Wyoming, and Wilkesbarre, on the Susquehanna. Dr. Rogers informed him that they were discovered in the same position in the continuation of the coal district in Virginia. Mr. Logan afterwards observed them in a similar position in the coal country of Nova Scotia. Mr. Lyell, who has devoted much attention to and carefully examined the underclays of the American coal fields, points out their common occurrence in that part of the world beneath the coal beds, so that some very general conditions must have produced those beds over so large a portion of the earth's surface, conditions with which the production of the coal itself would appear to be connected."**

"The remains of Stigmaria are so abundant throughout the whole of the carboniferous formation, that it is impossible to travel far along any road, without its form being detected by the practised eye. In 
some of the best and most closely observed instances of its mode of occurrence in the bed before described, the arms could be traced from the central dome, slanting downwards into the coal, where all trace of them was completely lost. Coal, which rarely bears any outward vegetable form, presents that of Stigmaria oftener than any other, and it is certainly one of the most abundant fossils of the whole formation, from which facts we should appear fully warranted in considering that the growth of plants of this class was one of the great means made use of by the Almighty architect of the globe, in absorbing and rendering solid that excess of carbon, which it is believed, must at the period of the formation of the coal measures, have existed in the atmosphere; thus rendering it fit for the support of animal life, and at last a proper habitation for man. We cammot contemplate this storing up such a mass of combustible matter, and the iron which always accompanies it in the depths of the earth, at a remote epoch, for the consumption and enjoyment of creatures afterwards to exist 
on its surface, without being struck with the benevolence and wisdom manifest in the design."*

The description given by the accomplished authors of the Fossil Flora of Great Britain, of the mode in which vegetable fossils occur in the lower coal beds near Edinburgh, conveys a forcible impression of the scenery of these silent forests.

"The fossils of Burdie house occur in a bed of limestone twenty-seven feet thick, remarkably compact, uncrystalline, and uniform throughout; the geological position of this limestone is low down, probably very near the base of the carboniferous groupe of rocks ; it is highly inclined, dipping with its immediately associated beds at an angle of $23^{\circ}$ in a S.E. direction from the trap of the Pentland Hills, the protrusion of which has evidently thrown them into the position they now hold.

"The vegetable remains occur in great profusion, and are to be found in every part of the limestone from top to bottom; and 
also, but more sparingly, in the shale beds above and below it. There are certain well defined natural partings or seams of stratification in the rock, which as they materially assist the working of the quarry, often expose an even surface of considerable extent; in these partings the remains of plants occur in greater abundance than anywhere else.

"When we last visited the quarry (May, 1835,) a large space was thus uncovered, which was thickly strewn over with elegant vegetable forms most perfectly preserved, the black colour of the carbonized plants contrasting beautifully with the light lavender-blue of the limestone. Sume idea may be formed of the profusion of the remains thus exhibited when we state that in a space, of three feet square, we counted upwards of forty specimens of Lepidostrobi, intermixed with Lepidophyllites almost without number, whilst scattered here and there might be observed the elegant form of Sphenopteris Affinis; so agreeable was the impression produced by the elegance of the forms, and the sober contrast of colour 
in the stone that it struck us, the calico printer or paper-stainer might here obtain a beautiful and certainly a novel device, for the ornament of his manufacture."**

The uniformity of plan which prevails to so great an extent throughout creation, and is exhibited in the frequent reproduction on a minor scale of phenomena elsewhere more largely developed, is remarkable also in the recurrence of small coal fields throughout the whole geological series. We notice first accumlations of fossil trees in the shales of the Lias above the carboniferous system; then coal and iron ore in thin beds in the lower Colite; afterwards lignite in the greensand; next coal and ironstone in the tertiary deposits at Aix in Provence; the brown coal of the Rhine and of Bovey in Devonshire; and lastly, the accumulations of peat, with thin flakes of bog-iron ore, spread like infant coal measures over the morasses of the present surface. The plants of the Oolite exist in sufficient quantities to constitute searns of coal, and supply profit- 
able collieries. This is the case in the North of Yorkshire, and at Brora in Sutherland. There are lignites, arising from peat forests of the present epoch, in the North of Germany, where the carbonized substance is extracted in blocks cut with the hatchet, and the supply is abundant. In the Rhine valley near Bonn, occurs a tertiary deposit called the brown coal formation from its containing bituminized wood in various states of mineralization; some trees apparently in situ, rooted where they grew, others prostrate and decayed. The wood is partially used as timber in building. The circumstances shew the growth and entombment of a forest on the banks of a freshwater lake, whilst the surrounding district was agitated by the volcanoes whose ancient eruptions have contributed to the picturesque features of the "enchanted river.

In the country of the Albigenses, coal is extensively worked in a freshwater tertiary formation. The firm blue limestones and regularly bedded shales, interstratified with carbonaceous matter, are on the plan if not on the scale of the true coal fields; but many 
of the insects now fixed in their ebon cabinet here, are similar to those which now flit over the plains of Provence; and the seed vessel of the chara, - the common weed of our little pools, denotes a comparatively recent origin for these deposits. The beautiful preservation of the insects, their lace-like wings and burnished armour in so rude a museum, is truly wonderful.

On the south eastern slope of Dartmoor, there is a large deposit of lignite at Bovey, called Bovey Coal, referrible also to the tertiary era.

One of the most remarkable of these mimic coal fields is displayed amidst the snows of Iceland. A substance called surturbrand, consisting of bituminized wood, occurs in regular subterranean layers throughout the whole of the north-western peninsula of that Island. It is used for the smithy, and in the manufacture of ornamental articles of household furniture.

The mode of its occurrence presents us with a forcible representation of the ancient forests growing in high northern latitudes on the volcanic slopes of that 
wonderful region, and there entombed amidst thunderings, lightnings, lava and ashes. We extract the following description from the well known Journal of Dr. Henderson.

The bituminized wood is found in strata alternating with lava, basalt, tufa, and indurated clay.

"The surturbrand is undermost, and occupies four layers which are separated from each other by intermediate beds of soft sand-stone or clay. These layers are of unequal thickness, from a foot and a half to thrce feet, and run to the length of about thirty yards, when they disappear in the debris. They aiffer also in quality: the two lowest exhibiting the most perfect specimens of mineralized wood, free from all foreign admixture, of a jet black; and such pieces as have been exposed to the sun shine with great lustre, and are very splintery in their fracture. The numerous knots, roots, \&c., and the amnual circles observable in the ends of the trunks or branches, removed every doubt of the vegetable origin of this curious substance. The only changes 
it has undergone are induration and compression; having been impregnated with bituminous sap, and flattened by the enormous weight of the superincumbent rocks. Some few branches stretch at times across the bed, but in general they all lie parallel with one another, and are frequently pressed together, so as to form a solid mass. The third stratum is not so pure, being mixed with a considerable portion of ferriginous matter; grey externally, but black in the fracture, has no lustre, and is much heavier than the former, yet possesses evident traits of its vegetable character. The fourth or uppermost stratum consists of what the Icelanders call steinbrand, or coal, from which it differs only in the absence of the gloss, and its containing a quantity of earthy matter. It still retains some faint marks of wood.

Remarkable as the appearance of this rock-wood undoubtedly is, a still more surprising phenomenon makes its appearance between the second and third strata, viz. a bed of dark grey schistus, about four inches in thickness, that admits of being divided 
into numerous thin plates, many of which possess the tenuity of the finest writing paper, and discover on both sides the most beautiful and accurate impressions of leaves, with all their ramifications of nerves, ribs, and fibres, in the best state of preservation. The whole of the schistose body is, in fact, nothing but an accumulation of leaves closely pressed together, and partially interlaid with a fine alluvial clay. It is also worthy of notice, that when you separate any of the leaves from the mass, they are uniformly of a greyish or brown colour on the surface, and black on the opposite side. Most of those on the specimeus now before me are of the common poplar, (populus tremula, and some of them, in the judgment of an eminent botanical gentleman,** appear to be of the populus talikamahaka. A few birch and willow leaves are also observable, but very small in size: whereas many of the poptar leaves are upwarls of three inches in breadth.

"Scouting the idea of a subtermean

* Professor Hormemann of Copenhagen. 
forest as too absurd to merit the slightest consideration, there are only three ways in which we can suppose the surturbrand to have originated. First, Large forests may have existed in this quarter of the island at a remote period, and may have been overturned and entombed during some of the volcanic revolutions of subsequent date. Secondly, It may be the remains of drift-timber, conveyed hither from the Missouri and other rivers in North America, or from the northern coasts of Siberia. Or, lastly, It may have grown in a former world, and been reduced to its present state in one of the great catastrophes which have so materially changed the surface of the earth."

After shewing that the first and second hypothesis are insufficient, our author proceeds.

"However, as the surturbrand is found in such immense quantities, and where it makes its appearance on one side of a mountain, it uniformly occurs, nearly about the same level, on the opposite side; as these mountains are of the more regular 
kind, consisting of numerous horizontal strata; and as, in many instances, fifteen or twenty of these strata are piled above the bed of mineralised wood, the theory will be freest from embarrassment that refers its entombment to one or other of those dreadful elemental conflicts to which the terraqueous globe has repeatedly been subjected. It formed perhaps part of the forests that grew on the sunk continent that now supports the Atlantic, and which on the submersion of that continent, must have been completely overturned, and carried in various directions, according to the motion of the currents. This hypothesis is corroborated by the fact, that the bed of surturbrand in the west of Iceland, runs uniformly in the direction of N. E. by N. N. E. ; and however broken and separated by the intervening bays and vallies, forms one continued stratum in the crust of the earth. That it is found to dip in some places more than others, is a necessary consequence of the earthquakes and volcanic derangements of subsequent date."* 
There are some accumulations of wood even now in course of formation which remind us of the phenomena of the coal measures.

Such are the lignites of North Germany already mentioned, the wood-hills of new Siberia, and the vast heaps of drifted timber, visible along the coasts of the northern seas; in some places interstratified with layers of sandstone, and bituminized in the process of decay. Such also must be the beds of lignite laid on the floor of the ocean at the mouth of the Mississippi, whose turbulent waters constantly bear forward the spoils of the mighty forests through which it flows. But none of these results are comparable, in point of extent, or amount, with the rich strata of our collieries.

It has been computed that the woody matter contained in the growth of a thousand years, in a dense tropical forest, would not constitute a layer of mineralized fuel half an inch in thickness. How is it then possible to assign to the present rate of agency of causes now in operation, the production of the numerous 
beds,- - some whose thickness is measured by many feet,- existing over one another, in the actually explored districts of our coal formation.

The interval between the old red sandstone or Devonian and the new red sandstone, is therefore entitled by way of eminence to the title of carboniferous, from the great predominance of the matter of coal within its minor successions. 


\section{CHAPTER VII.}

COAL MEASURES CONTINUED.

General view of Coal Measures in various parts of the Globe. Africa, Asia, Australia, America, Europe, and the British Isles. Mineralogy of Coal. Distortions of Strata. Faults. Advan. tages of actual Arrangements. References to history of the use of Coal. Statistics of the Subject.

"Nature all o'er is consecrated ground, Teeming with growths immortal and divine; The great proprietor's all bounteous hand Leaves nothing waste, but sows these fiery fields With seeds of reason."-Young.

A More extended view of the principal accumulations of fossil plants, which under the name of the coal measures, furnish such large contributions to the comforts and conveniencies of life, will not be misplaced in the present sketch of the ancient vegetation, whence all their stores were derived.

We have already seen that although coal 
is not absolutely confined to any one geological formation, but is present to some extent in nearly all, yet there is one series of rocks in which it greatly predominates. The great deposits of fossil fuel, are all of the same geological age, as estimated by the rude but certain chronology of the sequence of rocks.

The geological term for the series of limestone, sandstone, and shale, rocks, and clays, which lie over the old red sandstone, or inferior systems, and under the new red sandstone, or superior strata, and which usually contains subordinate beds of coal and ironstone, is "coal measures ;" and this though in some instances (as in North Devon) no true coal is found in them. The terms coal field, coal basin, are expressive of the same arca, but popularly restricted to the locality whence coal is actually obtained.

The progress of steam navigation, by inducing careful search for fossil fucl, has been the occasion of its discovery in most parts of the globe. Every year additions are made to the long list of its localities. The history of science continually records 
instances of the contemporaneous occurrence of two events, apparently independent of each other, yet linked together by relations quite as important as they were unexpected. No sooner does the distant sea, or the mighty river, bear on its bosom the fuel-devouring engine, than the explorer announces that in some adjacent land, coal has been discovered to supply its enormous demands. The extension of steam-power will have the ultimate effect of bringing into operation collieries throughout the world : and thus an art and occupation unknown to our forefathers, will unite in a fresh community of interest and pursuit, people of the most distant regions.

Africa, that country of exceptions and incognita, has not yet we believe any coal mines in work. Happy if its commerce were in a commodity less dark and foul than the merchandise of men.

Asia, displays coal mines in China, the Burmese Empire, Hindestan, Persia, and in Australia and Van Diemans land.

South America, on the coasts of the $\mathrm{Pa}$ cific, has disclosed extensive conl fields: 
the magazines of future enterprise and improvement.

North America possesses most valuable districts of coal from the tropics to the region of perpetual snow. An inexhaustible supply is partially explored in the United States. The coal measures of British North America are also of great extent and richness.

In Europe, from the borders of the Black Sea, from several places in Southeru Russia, from the South of France, Spain, Bohemia, Saxony, Belgium, Northern France, and Sweden, and from many other localities, this useful material is procured, and especially from the British Isles. In serenteen counties of Ireland, in the greater part of the Lowlands of Scotland, in about sixteen distinct districts in England, collieries have been successfully established.

The mode in which the mineral occurs is the same in all places, namely, in layers alternating with claystone or sandstones.

These layers or beds are inclined at various angles to the horizon, in some instances as in the neighbourhood of Bristol, the 
strata are actually vertical, and a shaft has been sunk for eighty fathoms in the same bed of coal.

The beds are not only thus inclined, but they are also disturbed by vertical dislocations, similar to those which are occasioned in the ice of a canal when the water is raised or lowered. The disturbances are sometimes mere shifts of the strata up or down, so that its continuity on the same level is simply interrupted, and the miner has to explore above and below in order to find the beds on which he had been previously working: at other times dense wedges of clay are interposed, and in other instances hard dykes or masses of igneous rock. There are places where the mineral composition of the bed becomes altered in the neighbourhood of these occurrences, and the rich bed of ore or coal, may gradually or suddenly become useless. A detail of these incidents, aptly termed by the colliers " troubles," will be found in treatises on inineral geology. They are all evidently the results of numerous fractures and movements accompanied by the ejection of gas, 
or vapour, or of molten rock, subsequently to the consolidation of the coal beds.

The broken appearance of rocks, to which is owing so much of their picturesque character in the landscape, is familiar to all lovers of scenery, and is principally owing to rents and fractures, not coincident with the orginal lamination of the mass, but of subsequent occurrence. In the most numerous class of instances, the broken strata do not lie in exactly the same plane, but the elevatory movement has thrown out of level one or other of the sides once evidently continuous. The line of fracture is sometimes a mere crack, at others a fissure filled with rubble from above, or with decomposed rock become clay, or a mass of crystalline porphyry or greenstone is inserted, and the communication intercepted between the one side and the other.

This state of things, which at first appears to be only calculated to produce disorder and confusion, and which in some cases certainly has this effect, is yet on the whole admirably contrived to render the minerals accessible and workable. 
The inclination downwards of a vein or coal-bed, would soon carry it beyond the reach of our powers, but the fracture (or fault as it is termed) dislocates the mass, and brings it again into useful proximity to the surface level. 'The dykes of clay and porphyry, if they obstruct the workman, yet they also obstruct his chief enemy the water, and thus operate as natural dams, which intercept and direct to the surface the subterranean streams which would otherwise immerse the mine beyond recovery.

An extended display of the mode in which the mineral riches of the globe are actually disposed, would constitute a description abounding with proofs of the actual wisdom of the arrangements of God, and the devout student will find these "dark unfathomed caves" as full of such gems as the better explored, and more attractive caskets on the earth's surface.

It appears to be impossible to contemplate the mineral kingdom, without coming to conclusions concerning the attributes of the Creator, in harmony with those 
which have been so triumphantly deduced from the gayer displays of existing life.

The law of increase by which the animal kingdom is maintained in numbers, has no counterpart in the mineral kingdom, but the mode in which metals are placed in the earth has much of the effect which would be produced by their actual growth. A progressive developement of their substance takes place not by reproduction, but by successive discovery.

Minerals yield their riches to each generation of mankind by the application of patient toil, the supply grows not by accretion of substance but under the hand of labour: whilst the quantity is really inexhaustible by man, it is practically limited by the measure of his power at any one time.

The effect of their actual arrangement is to call forth the mental and physical energies of mankind, to require him to visit various regions of the earth, to create the necessity and supply the medium of commerce; objects which no other disposition of these substances could have secured. 
The original laminations of strata, the subsequent convulsions, the electric currents, the slow crystallizations, the fiery agencies, the contractions and expansions, the growth and entombment of vegetables, the surface currents, have all been employed in providing for our daily benefits.

It is worthy of remark, that the quantity and mode of occurrence of each mineral bears an exact proportion to its comparative utility; the scale of relative production is graduated in correspondence to the wants of mankind. The more precious metals occur in thin veins or lodes, iron in larger deposits, coal in beds still more extensive, and salt (though more sparingly found) in masses of dimensions and purity greater than either.

Thus as in a grand orchestra, now one class of instruments sounds forth, and now another bursts on the ear, and all swell the same strain; so every province of the material universe gives its own separate melodious tribute of song to the universal. chorus-" All Thy works praise Thee!" The use of coal is an art of civilized life, 
there is rio instance on record of its employment amongst barbarian tribes.

The notices of its early history as fuel are extremely scanty. Three passages in the sacred Scriptures have been quoted to prove that it was not unknown in the days of Job and the prophets.* The arguments in favour of the hypothesisis that fossil fuel is thus referred to, are based not on translation, but on the force of the expressions used, and cannot be considered as establishing more than a possibility.

Theophrastus (B.C. 285) is quoted to shew its employment by the smiths in ancient Greece; the forge was apparently its sole consumer in the infancy of its use, and until comparatively modern days.

In this Island the etymology of the word is the most powerful argument that the substance was known to the Ancient Britous. The discovery of cinders under a Roman way, and in ruins of the Romano-British period, attest its occasional employment by the artizans of that transition state of

* Job xli. 21; 2 Samucl xxii. 9, 13; P'salm xriii. 8; quoted iu Dr. Kitto's Biblical Cyclopedia, Art. "Coal." 
military civilization. A grant to the Abbey of Peterborough in 853 gives evidence that the monks were acquainted with its value;* the notices of its use are scanty during the Plantagenet period, and it is not until Britain became distinguished for her manufacturing and commercial efforts that its importance became fully realized.

Thus has it ever been, the earth in its material stores and properties has been the handmaid of the mind of man : attending every step of his progress, yielding up her riches as he has acquired the power to use them.

Besides the enormous addition to the comforts and conveniences of life made by the fossilized forests of a former era, they also afford direct subsistence to an immense number of persons engaged in the commerce arising from their productions.

In the year 1700 London alone received 680,000 Tons of Coal from Newcastle, in the course of a century this became doubled, and for the last 17 years the quantities

* Vide Whitaker's Manchester, vol. 2, p. 37, 39. 
imported by sea, and the number of ships employed, have been as follows :-

\begin{tabular}{|c|c|c|c|c|}
\hline Importations. & & Ships. & & Tons. \\
\hline In 1832 & & 7,528 & 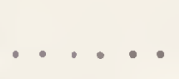 & $2,139,078$ \\
\hline In 1833 & $\ldots \ldots$ & 7,077 & $\ldots \ldots$ & $2,010,409$ \\
\hline In 1834 & $\ldots \ldots$ & 7,404 & $\ldots \ldots$ & $2,078,685$ \\
\hline In 1835 & $\ldots \ldots$ & 7,958 & $\ldots \ldots$ & $2,298,812$ \\
\hline In 1836 & . $\ldots$. & 8,162 & $\ldots \ldots$ & $2,398,35.2$ \\
\hline In 1837 & $\ldots \ldots$ & 8,720 & . . . & $2,626,997$ \\
\hline In 1838 & $\ldots \ldots$ & 9,003 & $\ldots \ldots$ & $2,581,085$ \\
\hline In 1839 & & 9,340 & & $2,625,323$ \\
\hline In 1840 & $\ldots \ldots$ & 9,132 & $\ldots \ldots$ & $2,566,899$ \\
\hline In 1841 & $\ldots \ldots$ & 10,311 & $\ldots \ldots$ & $2,909,144$ \\
\hline In 1842 & $\ldots \ldots$ & 9,691 & ... & $2,723,200$ \\
\hline In 1843 & $\ldots \ldots$ & 9,593 & $\ldots \ldots$ & $2,628,520$ \\
\hline In 1844 & $\cdots \ldots$ & $\mathbf{9 , 4 6 6}$ & $\ldots \ldots$ & $2,490,910$ \\
\hline In 1845 & $\ldots \ldots$ & 11,987 & $\ldots \ldots$ & $3,403,320$ \\
\hline In 1846 & & 10,488 & $\ldots \ldots$ & $2,953,755$ \\
\hline In 1847 & & 11,911 & $\ldots \ldots$ & $3,280,420$ \\
\hline In 1848 & & 12,267 & $\ldots \ldots$ & $3,418,340$ \\
\hline
\end{tabular}

To this must be added

By Canal in $1848 \quad \ldots \ldots \ldots \ldots$ 19,918

By Railway in $1848 \ldots \ldots \ldots$. 37,888

Making the total importation into London in the year $1848,3,476,146$ Tons. Add to this in due proportion the quantities consumed in the other great cities of the empire; and on the "domestic hearth" of its whole population; the demand of its manufactories

* Official Account, Coal Market, London, 1848. 
and mines; the exports; the fires at the pits' mouth; the active demand and supply in Belgium, and elsewhere abroad; the steamers wending their way in every ocean;-and the results both as to supply of fuel, and employment of labour will appear to be truly wonderful. When we consider that all this vast provision originated in the tangled forests of by-gone ages, prepared and garnered by processes of consummate power and skill, we cannot withhold the tribute of grateful admiration.

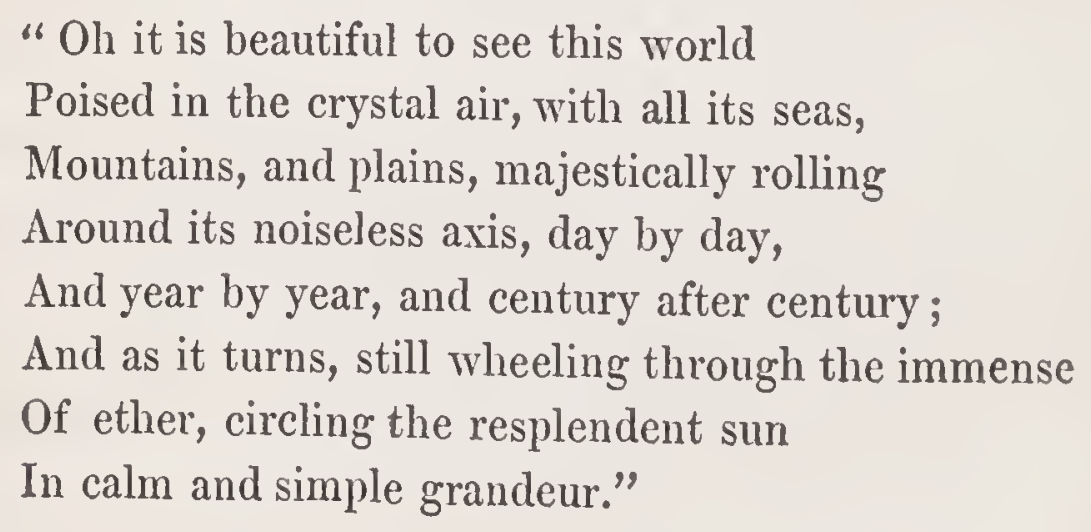




\section{CHAPTER VIII.}

BOTANY OF PALNOZOIC ROCKS.

Difficulty of determining between the Strata of older Rocks. Instance from North Dcvou. Devonian System. Silurian. Cambrian. Paucity of Organic Remains. Plants in the old Red Sandstone. In the Silurian and lower Rocks. Sca-Weed, Ancient and Modern. Earliest appearance of Lifc, and remarks on its Charaeter.

"Or speak to the earth and it shall teach thec;

And the fishes of the sea shall declare unto thec!

Who knoweth not in all these,

That the hand of the Lord hath wrought this?"

$J_{0 b}$ xii. $8,9$.

After lingering so long amidst the collieries the remainder of our geological tour will be but brief. We set out from London purposing to reach the picturesque outlines of the grantic ridges. Ere we arrive at these, we have still to traverse a vast extent of hard sandstone and slate country, lying on the 
flanks and minor undulations of the elevated district which bounds the horizon. The interior of this area will furnish but little to attract the botanist, in comparison with the upper formations. Vast ranges of the old rocks are destitute of the traces of organic life, although belonging to formations in which fossils occur.

The unproductive strata of fossiliferous formations may be compared to deserts, where the explorer derives an aching sensation of wearisome loneliness, as one plain. after another rises sharply to the horizon without a trace of a living creature. The frequent recurrence, and enormous extent, of sheets of sedimentary matter entirely destitute of organic forms, in immediate succession to other layers teeming with the exuviæ of animals, or plants, is a phenomenon often encountered by the geologist.

The writer was recently proceeding through an uninteresting portion of North Devon, where this observation is abundantly verified. For twenty-two miles the yellow roads lead over a succession of dull low hills, in the cuttings and banks a coarse 
shaly rock only was visible, barely removed in composition from the intervening clay. Not a fragment of foreign matter appeared, but on attaining a place called Woodford Bridge, where the country became (in mining phrase) harder for a short space, the road side was strewed with dark sandstones, glittering in the sunshine with abundant remains of reed-like plants. Jointed and fluted stems and small grassy leaves, in inconceivable profusion but imperfect state, shewed that once this wilderness of muddy matter was diversified by the graceful growth of a tropical marsh, and that the whole series belongs to the coal measure and not to the slate.

Near Bideford the same thin intercalation of plant-bearing strata, with thick barren rocks occurs. In the noble cliffs which form the gorge of the river Torridge, there may be seen extending for half a mile, high rocks nearly vertical, so that the quarries, unlike most excarations, display smooth sides, and printed on some few of these, are the indelible traces of delicate vegetation. Silvery calamites, the leaf probably 
of a palm, (Poacites Cocoina,) and fragments of the trees called Sternbergia and Sigillaria, attest the former existence of flourishing groves, separated from each other by vast intervals of time, during which layer after layer of thick hard sediment accumulated on the buried soil. The carboniferous matter in this locality is usually but a thin film, sometimes a distinct seam, and at one or two places large enough to tempt the adventurer to extract it; but the whole forms a profitless representation of the productive coal measures of other and more favoured spots. Alike in the coarse slaty character of their composition, and in the tokens of flexure and disturbance, it is extremely difficult, without the aid of fossils, to separate the culm-bearing strata from the older rocks.

We have to speak of the Devonian and Silurian systems, which will exhaust the catalogue of fossiliferous deposits. All beneath are either sedimentary rocks so altered as to obliterate all traces of organic life, or crystalline masses, which have evidently suffered more than a "sea-change," and bear proofs of former fusion. 
The groupe of rocks comprising deep red sandstones, slates, and limestones, in Scotland and the marches of Wales; and in Devonshire exhibiting pale grey and green deposits, with subordiate red beds; is now termed the Devonian. It extends over a considerable portion of the slate districts of the globe, and in Russia alone occupies an extent of one hundred and fifty thousand square miles. These rocks are the immediate predecessors of the mountain limestone and coal.

Next, we have a second groupe of hard rocks, taking an inferior position, and which, from the district of their chief development in Britain, (the country of the ancient $\mathrm{Si}$ lures,) are termed Silurian. Below the latter, but with questionable right to the honour of a separate nomenclature, lie the slates of the Cambrian system. As these however are really undistinguishable, and in fact zoologically identical with the lower Silurian, the term will probably be dropped; the Silurian and Devonian names will reign over a territory extending from the furnaces of the coal measures, to the peaks of the 
primitive hills. We are thus introduced into the domains of pure physical force, unaccompanied by any traces of life, save the evidences of the exercise of mighty power which the masses themselves everywhere display.

The student must not, however, conclude from such enumerations that the old hard rocks are easily reduced into system and known at first sight. Though existing in substance so considerable that one groupe, the Silurian, in one place, is estimated to be a mile and a half thick, yet the detection of their true order and character is by no means easy. The striking mineral differences which distinguish the members of the higher formations, the clay, chalk and oolite, do not obtain among the severe aspects of the slate rocks. Hence when we find only one of the latter exhibited, and that, either totally, or in a large area devoid of organic remains, it is with difficulty that its geological position is determined; and thus the downs and defiles of Cornwall, Wales, and the Rhine-land, have been the scenes of protracted modern warfare be- 
tween the champions of rival systems; and truth has been won at the point of the hammer, after many years of conflict.

It is also to be observed, that although these groupes have a real separate existence, yet the exact line of demarcation is often obscure, a result which points to modified actions of a common cause, operating during the time of the whole deposit.

The interest which attaches to the study of organic remains, led its admirers first to the attractive and easy investigation of the soft upper beds, whence the prey could be extracted with the lustre of recent life. These tempting provinces having been explored, the wonder-seekers have been led farther and farther back in the pursuit of their game, until each belt of the dark forest has been in turn ransacked and described, and almost every station has had its own geographer. So large is the science, that it requires and repays the enthusiasm with which separate observers attach themselves to the succeeding stages of the past, and as each unrolls the record of his own discoveries he asserts with parental foudness the superior merits of his own choice. 
The plants which are named by Mons. Adolphe Brogniart as having been discovered in these strata, (Terrain de transition) are, four Fucoids, two Calamites, three Ferns, two Sigillaria, and one Lepidodendron, but he leaves it doubtful whether the land plants do not belong to the base of the coal formation. The present result of re searches into the deposits below the mountain limestone, is that no decided trace of land is to be found. Mr. Miller says of the old red sandstone in his graphic and able book on that formation, "The vegetable remains of the formation are numerous but obscure, consisting mostly of carbonaceous markings, such as might be formed by comminuted sea-weed. Some of the impressions fork into branches at acute angles: some affect a waved outline; most of them however are strait and undivided. They lie in some places so thickly in layers as to give the stone in which they occur a slaty character. One of my specimens shews minute markings, somewhat resembling the bird-like eyes of the Stigmaria Ficoides of the coal measures; the branches of another termi- 
nate in minute hooks, that remind one of the young tendrils of the pea when they begin to turn. In yet another there are marks of the ligneous fibre: when examined by the glass, it resembles a bundle of horsehairs lying stretched in parallel lines; and in this specimen alone have I found aught approaching to proof of a terrestrial origin. The deposition seeins to have taken place far from land; and this lignite, if in reality such, had probably drifted far ere it at length became heavier than the supporting fluid and sank. It is by no means rare to find fragments of wood that have been borne out to sea by the gulf stream from the shores of Mexico or the West Indian islands, stranded on the rocky coasts of Orkney and "Shetland." **

The impressions of marine vegetables are not very common amidst the layers of zoophytes: whilst hammering the old slate rocks of the Devonian system, thousands of feet beneath the coal, we have been occasionally startled by the sharp sculpture of a

* Old Red Sandstone, by Hugh Miller, p. 100. 
delicate sea-weed, extending its tiny branches on the surface of the stone.

By what a wonderful process has this waif been drifted down the stream of the unreckonable past to be cast up at the feet of the explorer of to-day. What revolutions of the solid globe, what convulsions, elevations, fires and floods, have left it unscathed, a silent testimony of still earlier phenomena; the witness from an epoch so mysteriously remote, that it appears linked rather to past eternity!

"Thus He who makes and peoples worlds still works In secrecy, behind a veil of light;

Yet through that hiding of his power, such glimpses

Of glory break as strike presumption blind, But humble and exalt the humbled soul, Whose faith the things invisible discerns, And God informing, guiding, ruling, all :He speaks, 'tis done; commands, and it stands fast. He calls an island from the deep,-it comes; Ordains it culture,-soil and seed are there; Appoints inhabitants,-from climes unknown, By undiscoverable paths, they flock Thither ;-like passage-birds to us in spring; They were not yesterday,-and lo! to-day They are,-but what keen eye beheld them coming ?" Montgomery. 
The fossiliferous shelly beds of the transition seas are on the whole remarkably destitute of vegetable remains.

The bays of the most ancient shores may have had the glowing coloured fringes which adorn those of the present; but if such were the case, few specimens only have survived, the action of a printing process so rude as that to which the organisms of the slates been subjected.

The result of an examination at the base of the Silurian deposits, whether in Russia, England, or North America, has been to shew that the remains of sea-weed are the earliest or deepest discoverable indications of vegetation. This was of course to be expected from their associates of the animal kingdom, the mollusks and cephalopods of the lower Silurian, the fishes of the upper portion, and of the Devonian.

We have arrived at the floor of organic life, the deepest level which we can reach; we find that these "dark unfathomed caves" are flashing with richer gems than crystals of "purest ray serene," for they display the skilful beautiful works of the Lord and giver of life. 
Professor Lindley remarks concerning the tribe most frequently found fossil in the transition rocks, "Algæ are most important in the economy of nature for forming the commencement of soil by their deposits and decomposition. The basin of the ocean is said to be continually rising by the deposit of such plants, particularly of conferva chthonoplastes, the closely aggregated fibres of which form dense beds. We find latitude, depths, currents, influencing the forms of algæ in nearly the same way as latitude, elevation, and station, affect those plants which are more perfect. The number of species is scarcely capable of being estimated."*

Although the oceans occupied so much of the ancient earth at various periods of its history, yet the modern developement of marine vegetation is larger than we have any example of in former time.

Algæ and their traces are sometimes found in isolated fragments in the older rocks; probably many of the carbon-

* Lindley's Introduction to Botany, 341. 
aceous stains, so frequent amidst the slates, owe their origin to the decomposition of small sea-weeds; in the upper rocks we again find them with sufficient character to indicate climate: but the present earth, in the waving foliage of its deep seas, presents an ample and various assemblage of forms to which our fossil deposits afford no adequate parallel.

The botanist tells us of a vegetable world beneath the waters, extending from pole to pole, divided into regular floral provinces, existing from the boundaries of perpetual darkness below, to the sunshine of the surface above, bearing marine counterparts of the minutest moss on the one hand, and of the most gigantic parasite on the other. Large spaces in the Atlantic are occupied by these submarine tangled forests, in one place covering two hundred and sixty thousand miles of surface; presenting the same appearance to the mariner now as in the days when the astonished discoverers of the American continent encountered it in their adventurous path, and named it the great sea-reed meadow. 
The fossil botany of the algæ is very incomplete, and we may expect that future researches will considerably extend the meagre list of present discoveries in this department of phytology.

The following description given by Mrs. Somerville of the marine vegetation of the existing seas should stimulate the geologist to ascertain to what extent the deep oceans inhabited by the spirifers and ammonites of early eras, and the mediæval shallows wherein the saurian floated, may have exhibited similar fields.

"Sea-weeds adhere firmly to the rocks before their fructification, but they are easily detached afterwards, which accounts for some of the vast fields of floating weeds; but others, of gigantic size and wide distribution, are supposed to grow unattached in the water itself. There are permanent bands of sea-weed in our British Channel and in the North Sea, of the kind called Fucus Filum, which grow abundantly on the western coasts of the Channel, and they lie in the direction of the currents, in beds 15 or 20 miles long and not more than 
600 feet wide. These bands must oscillate with the tides between two corresponding zones of rest, one at the turn of the flood, and the other at the turn of the ebb. It is doubtful whether the Fucus natans or Sargassum bacciferum grows on rocks at the bottom of the Atlantic, between the parallels of $40^{\circ}$ north and south of the equator, and, when detached, is drifted uniformly to particular spots which never vary, or whether it is propagated and grows in the water; but the mass of that plant, west of the Azores, occupies an area equal to that of France, and has not changed its place since the time of Columbus. Fields of the same kind cover the sea at the Bahama Islands, and other places, and two new species of it were discovered in the Antarctic seas.

"The Macrocystis pyrifera and the Laminaria radiata are the most remarkable of marine plants for their gigantic size and the extent of their range. They were met with on the Antarctic coasts two degrees nearer the south pole than any other vegetable prorluction, forming, with one remarkable 
exception, the utmost limit of vegetable life in the south polar seas. The Macrocystis pyrifera exists in vast detached masses, like green meadows, in every latitude from the south polar ocean to the 45 th degree $\mathrm{N}$. Lat. in the Atlantic, and to the shores of California in the Pacific, where there are fields of it so impenetrable, that it has saved vessels driven by the heavy swell towards that shore from shipwreck. It is never seen where the temperature of the water is at the freezing-point, and is the largest of the vegetable tribe, being occasionally 300 or 400 feet long. The Laminaria abounds off the Cape of Good Hope and in the Antarctic Ocean. These two species form great part of a band of sea-weed that girds Kerguelen Islands so densely, that a boat can scarcely be pulled through it; and they are found in great abundance on the coasts of the Falkland group, and also in vast fields in the open sea, hundreds of miles from any land: had it ever grown on the distant shores, it must have taken ages to travel so far, drifted by the wind, currents, and the sand of the seas. The red, green, and pur- 
ple lavers of Great Britain are found on the coasts of the Falkland Islands; and, though some of the northern weeds are not found in the intervening warm scas, they re-appear here. The Lessonia is the most remarkable marine plant in this group of islands. Its stems, much thicker than a man's leg, and from 8 to 10 feet long, fix themsclves by clasping fibres to the rocks beyond the high water mark. Many branches shoot upwards from these stems, from which long leaves droop into the water like willows. There are immense submarine forests off Patagonia and Tierra del Fuego, attached to the rocks at the bottom. These plants are so strong and buoyant, that they bring up large masses of stone; and, as they grow slanting, and stretch along the surface of the sea, they are sometimes 300 feet long. 'The quantity of living creatures which inhabit these marine forests and the parasitical weeds attached to them is inconceivable, they absolutely teem with life. Of the species of marine plants which are strictly antarctic, including those in the seas of $\mathrm{Van}$ Diemen's Land and New Zealand. Dr. 
Hooker has identified one-fifth with the British Algæ.

"The high latitudes of the Antarctic Ocean are not so destitute of vegetation as was at first believed. Most minute objects, altogether invisible to the naked eye, except in mass, and which were taken for siliceous shelled animalcules of the infusoria kind, prove to be vegetable. They are a species of the Diatomaceæ, which, from their multitudes, give the sea a pale ochreous brown colour. They increase in numbers with the latitude, up to the highest point yet attained by man, and no doubt afford the supply of food to many of the minute animals in the antarctic seas. Genera and species of this plant exist in every sea from Victoria Land to Spitzbergen. It is one of the remarkable instances of a great end being effected by small means; for the death of this antartic vegetation is forming a submarine bank between the 76th and 78th parallels of south latitude, and from the 165th to the 160th western meridian.

"Great patches of Confervæ are occasionally met with in the high seas. Bands 
several miles long, of a reddish-brown species, like chopped hay, occur off Bahia, on the coast of Brazil; the same plant is said to have given the name to the Red Sea, and different species are common in the Australian Seas."**

Much has been said and written about the simplicity of the earlier forms of animal and vegetable life; there is evidently an error in the ordinary application of terms on this subject, inasmuch as the most highly organized vegetable, and the lowest in the scale, are alike framed of tissue which displays the same equally perfect contrivance.

Viewed under the microscope, the threadlike sea-weed is as full of exquisite arrangements as the stem of the lily, or the branch of the oak, and all are equally far removed from inorganic matter. The opulence of creation is more displayed in the present scene than in the relics of former vegetation, and better seen in the torrid than in the arctic zone, and more conspicuous in the forest than in the plain; but the handiwork

* Physical Gcography, vol. ii, p. 211. 
of infinite skill, the operations of Him whose way is perfect, are as real in the one case as the others,

There is undoubtedly a kind of progressive order in the multiplication of organic forms during successive formations, but it is evidently the order of express appointment, and not of self evolution. The order, like the forms themselves, will doubtless appear to be the wisest and best possible, in that glorious era when we shall be permitted, with exalted faculties, to review the whole of that which we see now in part only.

\footnotetext{
"Ah how the human mind wearies herself

With her own wanderings, and involved in gloom Impenetrable, speculates amiss!

Measuring in her folly, things divine

By human; laws inscribed on adamant

By laws of man's device; and counsels fixed

For ever, by the hours that pass and die."
}

Cowper, from Milton's Latin Poems.

There is something impressive to the thoughtful mind in the consideration of the pristine relics which fossil botany displays. They have come down to us as witnesses that God is not only the same yester- 
day, to-day, and for ever, in the grand attributes of his nature, but also in the graceful beauty of his works. The matchless skill and elegance exhibited in the leaf of a fossil fern, are early displays of the marvels of the same creation as that in "which we live, and move, and have our being." 


\section{CHAPTER IX.}

STATISTICS OF FOSSIL BOTANY.

Difference between species the ground of our Researches. Modern rise of the Study. Table of Professor Göppert. Contrast with the present. Mr. Morris's Table of Fossils in British Strata. Other Tables. Review and Conclusions.

"_- dont nous cherchons les lettres symboliques,

D'un passé sans mémoire incertaines reliques, Mystères d'un vieux monde en mystères ecrit!"

Lamartine.

The measure of certainty which geological or rather palæontological researches present, and much of the interest which attaches to them after the first impulse of uninstructed wonder has subsided, are owing to our being able to affirm the agreements and differences between species ancient and modern. The same laws have prevailed at all periods of life of which we 
have any record. The same generai plan, the same rigorous separation between kinds, the same diversity between individuals, the same grouping of species into tribes and families, the same leading divisions of God's works in this province of creation. We need no new grammar of natural history for the study of fossil remains, the present is the key to the more scanty past, the syntax is the same, though the words are different.

The animals and plants figured on sculptures from Nineveh, found in the tombs of Egypt, and described in the pages of inspired scripture, alike testify to the identity of species throughout all time. It is now well established by the demonstrations of Owen, the illustrations of Dr. Prichard, and of Professor Forbes, and the independent evidence of many eminent physiologists, that the occurrence of a new species in creation would be an event of which we have no similar instance during the historical era.

The science of fossil botany is probably yet only in its infancy; twenty-five years since there were not one hundred fossil 
plants specifically known and determined. In the first quarter of the present century the facts of our science were still regarded by many persons as uncertain marvels, magnified by the haze which surrounded the whole subject of geology. Brongniart, in 1828, collected and methodized the scattered labours of his predecessors, and gave unity and interest to the study. He enumerates 501 species, and this number has been increased upwards of three-fold since the date of his first publication.

In the present day no picture of physical life can be complete without a representation of the earth's ancient flora; it brings its contingent force to the great army of phenomena, by which the faculties of our intellectual and moral being are challenged to investigation.

Considering the extensive size of its field, and the little time yet spent in its cultivation, it may appear premature to enrol the facts already discovered, and reason from the qualities of their proportions; but the tables constructed from present discoveries, are probably very near approximations to 
the whole truth, in regard to relative quantities.

The most recent general account of the genera and species of fossil plants is that of Mons. Göppert, of Breslau, * of which we extract a summary.

\begin{tabular}{|c|c|c|}
\hline & Families. & Species. \\
\hline Tertiary strata. Middle and Upper & 52 & 327 \\
\hline Lower ... & 10 & 120 \\
\hline do. Monte Bolca. & 4 & 7 \\
\hline Chalk.. .. & 1 & 3 \\
\hline Lower do. (Greensand) .. & 15 & 59 \\
\hline Oolite. Wealden .. .. & 8 & 16 \\
\hline 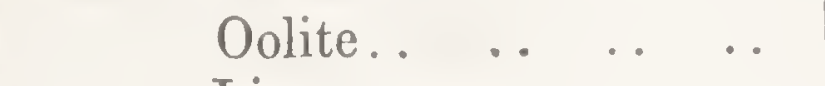 & 9 & 159 \\
\hline $\begin{array}{llll}\operatorname{Lias} & \ldots & \ldots & \ldots\end{array}$ & 12 & 75 \\
\hline $\begin{array}{c}\text { Trias. } \\
\text { Muscher Marls kalk }\end{array}$. .. .. & $\begin{array}{l}8 \\
2\end{array}$ & $\begin{array}{r}52 \\
2\end{array}$ \\
\hline Gras bigarré $\quad \ldots$ & 8 & 32 \\
\hline Permian. Magnesian limestone & 3 & 19 \\
\hline New Red Sandstone & 4 & 39 \\
\hline 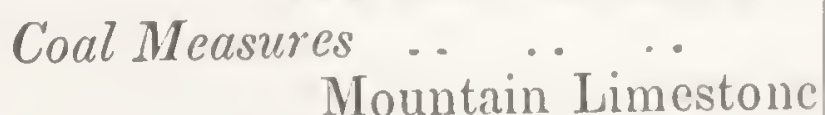 & $\begin{array}{r}18 \\
3\end{array}$ & $\begin{array}{r}816 \\
3\end{array}$ \\
\hline $\begin{array}{l}\text { Mountain Limestonc } \\
\text { Palcozoic Rockis. . . . . . . }\end{array}$ & & s \\
\hline $\left.\begin{array}{l}\text { Devonian } \\
\text { Silurian }\end{array}\right\}$ & S & 52 \\
\hline Uncertain & 4 & 11 \\
\hline Totals... . . . & 169 & 1792 \\
\hline
\end{tabular}

* Journal of Geological Society No 4. 
There are about eighty thousand species of existing plants discovered throughout the world. The fossil species form therefore only one forty-fifth of the present, and after making the largest allowance for the numbers which may yet remain undisturbed in their catacombs, yet the disparity remains very great; adding to the differences already established between the existing and the former state of things on the surface of the globe.

We are able to give a more complete view of the fossil botany of Britain than of any other country. The following table is compiled from Mr. Morris's careful and elaborate "Catalogue of British Fossils," by the kind permission of the author of that work. It has been re-arranged in the order of the strata, the genera being distributed alphabetically. There are some species of subsequent discovery noticed in the proceedings of the Geological Society, but the latter are not so numerous as to affect any conclusions which may be drawn from the present list. 


\section{FOSSIL PLANTS IN BRITISH STRATA.}

\section{Tertiny Formations.}

GENERA.

SPECIES.

AVENTACE.E, ... . remains of, CARPOLITHES, ..ovulum,

thalictroides,

CERATOPHYLLUM,demersum, CIIARA......... helicteres, hispida, Lemani, Medicaginula, tuberculata vulgaris, CUCUMITES,..... variabilis, CUPANOIDES, .... corrugatus, depressus, grandis, inflatus, lobatus, pygurus, subangulatus, tumidus,

CUPRESSINITES, Comptoni, corrugatus, crassus, curtus, clongatus, globosus, recurratus, semiplotus,
LOCALITY.

Bournemouth. Plastic Clas Isle of Wight. Paris. Lower Freshwater.

Isle of Wight. Paris. Normandy. Germanr. Mundesley.

Upper Freshwater. Forfarshirc.

Lower Freshwater. ditto. ditto. do. and Marl Lakes. Sheppy. London Clay. ditto. ditto. ditto. ditto. ditto. ditto. ditto. ditto. ditto. ditto. ditto. ditto. ditto. ditto. ditto. ditto. 
GENERA.

SPECIES.

LOCALITY.

CUPRESSINITES, subangulatus, Shcppy. London Clay。 (continued.) subfusiformis, ditto. sulcatus, ditto. tessellatus, ditto. Thuoides, ditto.

FABOIDEA, ๑: .... acuta, ditto. bifalcis, ditto. complanata, ditto. crassa, ditto. crassicutis, ditto. doliformis, ditto. larga, ditto. longiuscula, ditto. marginata, ditto. oblonga, ditto. ovata, ditto. pinguis, ditto. plana, ditto. planimeta, ditto. planodorsa, ditto. quadrupes, ditto. robusta, ditto. rostrata, ditto. semicurvilinearis, ditto. subdisca, ditto. subrobusta, ditto. subtenuis, ditto. symmetrica, ditto. tenuis, ditto. ventricosa, ditto.

FUCOIDES, ...... large species, Brentwood. London Clay, HIGHTEA, ........ attenuata, elegans, elliptica, fusiformis, inflata, Sheppy. London Clay. ditto. ditto. ditto. ditto. 
GLNERA.

$\begin{aligned} & \text { HIGHTE } \Lambda, \ldots . . . \text { minima, } \\ & \text { (continued.) } \text { orbieularis, } \\ & \text { oviformis, } \\ & \text { turbinata, } \\ & \text { turgida, }\end{aligned}$

LAURACE E, ..... remains of

LEGUMINOSITES, xquilateralis, cordatus, crassus, eurtus.

dimidiatus, elegans, enormis, gracilis, ineonstans, lentiformis, lobatus, longissimus, planus, reniformis, rotundatus, subovatus, subquadrangularis, trapeziformis, I. YCOPODITES, . . . squamatus, MIMOSITES, ...... Browniana, NIPADITES, ...... acutus, elavatus, eordiformis, erassus, elliptieus, giganteus, lanecolatus, Parkinsonis, pruniformis, pyramidalis,
LOCALITY.

Sheppy. London Clay. ditto. ditto. ditto. ditto.

Bournemouth. Lon. Clay. Sheppy. London Clay. ditto. ditto. ditto. ditto. ditto. ditto. ditto. ditto. ditto. ditto. ditto. ditto. ditto. ditto. ditto. ditto. ditto. Sheppy. Paris. Ossington. London Clay. Sheppy. London Clay. Sheppy. Prinrose Hill. Sheppy. London Clay. ditto. ditto. ditto. ditto. ditto. ditto. ditto. 
GENERA. SPECIES.

NIPADITES, ...... semiteres, (continued.) turgidus, umbonatus,

PETROPHILOIDES, celluraris, conoideus, cylindricus, ellipticus, imbricatus, oviformis, Richardsonii,

PINITES, ....... Dixoni,

STROBILITES, .... Woodwardii, TRICARPELLITES, aciculatus, communis, crassus, curtus, gracilis, patens, rugosus,

WETHERELLIA, .. variabilis, XULIONOSPRIONITES, latus, Zingiberiformis,
LOCALITY.

Sheppy. London Clay. ditto. ditto.

Herne Bay. London Clay. ditto. ditto. ditto. ditto.

Sheppy. Herne Bay. Sussex. London Clay. Mundesley. Plastic Clay. Sheppy. London Clay. ditto. ditto. ditto. ditto. ditto. ditto.

Sheppy. London Clay. Sheppy. London Clay. ditto.

\section{Chalk.}

CARPOLITHES, .. Smithiæ, CONFERVITES,.... fasciculata,

another species,

FUCOIDES, ...... Brongniarti,
Sussex,

Lewes. Wilts. Norwich. Hamsey. Bornholm. Chalk and Chalk Marl. Lewes.

Lewes.

III. Greensand.

ABIES Benstedii, Maidstone. 
GENIRA.

SPECIES.

ABIES, (continued.) oblonga, CHONDRITES, .... Targionii, CONFERVITES,... faseiculata, DRACENA, ...... Benstedii, FUCOIDES, ......

STROBILITES, .... Bucklandii, ZAMITES, ....... macroeephalus, ovatus, Sussexiensis, Lyme Regis. I.OCALITY.

Bignor.

Maidstone. Greensand. ditto.

Morlington. Gault. Wilts.

Deal.

Feversham.

Selmeston.

IV. WEALDEN.

CARPOLITHES, .. Mantelli, CLATHRARIA, .... Lyellii, ENDOGENITES, .. erosa, EQUISETITES, .... Lyellii, LONCHOPTERIS, Huttoni, Mantelli,

PTEROPHYLLUM, Brongniarti, SPHENOPTERIS, Mantelli, Phillipsii, Sillimani,

ZAMITES, ......crassus,

\section{Oolite.}

ALETHOPTERIS, .. insignis, ? Phillipsii, ? BRACIIPII YLLUM, manmillare, BUCKLANDIA, . . . squamosa, CARPOLITHES, .. arcolatus, Bucklaudi, conicus,

CYCADITES, .... Nilssonii, CYCLOPTERIS, Beanii,
Tilgate Forest. ditto. - ditto.

Pounceford.

Wansfield.

Tilgate. Beaurais.

Heaver's Wood Common. Tilgate. Pounceford, Wilts Heatlifield, Wilts. ditto.

Tilgate.

Gristhorpe Bay. Shale. Cayton. Shale.

Haiburn Wyke. Shale. Stonesfielı. Great Oolitc. Scarborough. Oolite. Malton. Coral Oolite. do.

Yorkshire. Oolite.

Gristlorpe Bay. Shale- 
GENERA.

SPECIES.

CYCLOPTERIS, .. digitata, (continued.) Huttoni,

DICT YOPHYLLUM, rugosom, EQUISETITES,... columnaris, lateralis,

HALYMENITES, .. ramulosus, LYCOPIDITES, .... falcatus, NEUROPTERIS, .. recentior, OTOPTERIS, ...... acuminata, graphica, PACHYPTERIS, . lanceolata, ovata, PALEOZAMIA,.... dubia, falcata, lanceolata pecten, pectinata, taxina,

PECOPTERIS, .... acutifolia, denticulata, exilis, Haiburnesis, Huttoniana, ligata, Lindleyana, lobifolia, obtusifolia, tenuis, undans, Whitbiensis, Williamsonsis,

PHLEBOPTERIS, .. contigua, polypodioides, PINITES, ....... Eggensis, primævus, PODOCARYA, .... unnamed,
L OCALITY.

Scarborough. Shale. ditto.

Gristhorpe Bay. Gt. Oolite. Yorkshire. Brora. Shale. Haiburn Wyke. Gt. Oolite. Stonesfield. Great Oolite. Cloughton. Shale. Gristhorpe. Shale. ditto.

Scarborough. Shale.

Saltwick. Shale. ditto.

Yorkshire. Great Oolite. Whitby. Lower Oolite. Yorkshire. Great do. Gristhorpe. Great do. Stonesfield. ditto. ditto.

Redcliffe Bay. Shale. Scarborough. do. Gristhorpe. do. Haiburn. do. Gristhorpe. do. Cloughton. do. Scarborough. do. Haiburn. do. Redcliffe Bay. do. Yorkshire. do.

Gristhorpe. do.

Cloughton. do.

Scarborough. do. Gristhorpe. Great Oolite. ditto.

Scuir of Egg. Hebrides. O. Burcottwood. L. Oolite. Charmouth. do. 
GENERA.

SPECIES.

POLYPODITES, . . crenifolius, Lindleyi,

POLYSTICHITES, murrayana, PTEROPHYLLUM, comptuin, minus, Nilssoni, tenuicaulis, Williamsonis, RHODEA, ....... macrophylla, Williamsonis,

SAGENOPTERIS, . . cuneata, Phillipsii, SCIIIZOPTERIS, .. gracilis, SOLENITES, ..... furcatus, murrayana, SPH FREDA, ....p paradoxa,

SPHENOPTERIS, . a arguta, athyrioides, erenulata, cysteoides, dentieulata, LOCALITY.

Gristhorpe. I. Oolite. ditto.

Scarborough. Shale. ditto. ditto. ditto.

Gristhorpe. Shale. Whitby. Lower Oolite. Stonesfield. Gt. Oolite. Gristhorpe. Shale. ditto. do. ditto. dlo.

Scarborough. do.

Haiburn. do.

Redeliffe. Gt. Oolite.

Cloughton. Gristhoope. Great Oolite.

Searborough. Shale.

Saltwick. Whitby.

Yorkshire. Shale.

Stonesfield. Great Oolite.

searborough. Shale.

hymenophylloides, Grist horpe.

muscoides, Saltwiek. Shale.

serrata,

SPHEROCOCCITES, areuatus,

TAXITES, ....... pollocarpoides, TENIOPTERIS, . . Iatifolia,

major, ovalis, seitaminea, vittata,

TIIUYTES, ...... articulatus, eupressiformis, Cloughtou. Searho'. Silnale. Gristliorpe.

Stonesfield. Cit. Oolite. ditto.

Gristlorpe. Sliale. ditto.

Stonesfield. Gt. Uolite. Whitby. Gristhorpe. Hor. Stonestieln, Git. Oolite. ditto.

ditto. Solenlofen. ditto. Scarborough. 
GENERA.

SPECIES.

TYMPANOPHORA, racemosa, simplex,

WALCHIA, ..... Williamsonis, ZAMITES, ......g.gigas, lanceolatus, longifolius, megalophyllus, microphyllus, undulatus,

VI. LIAS.
ARAUCARITES, .. peregrinus, OTOPTERIS, ..... obtusa, PAL EOZA MIA, .... Bechei, Bucklandi, PEUCE, ........ Eggensis, Huttoniana, Lindleyaur, SPHEROCOCCITESgranulatus, STROBILITES, .... elongata, ZAMITES, ....... pygmæus,
LOCALITY.

Cloughton. Shale. ditto.

Saltwick. Shale.

Scarborough. do.

Haiburn. do.

Gristhorpe. do.

Portland Isle. Oolite. ditto.

Yorkshire. Shale.

\section{NEw RED Sandstone.}

CALAMITES, .... Mougeotii, CREPIDOPTERIS, macrophylla, DICTYOPHYLLUM, crassinervium, ECHINOSTACHYS, oblongus, EQUISETITES, .... columnaris,

VOLTZIA, ....... Phillipsii,
Lyme Regis.

Membury. Polden Hill. Axminster. Mammers. ditto.

Isle of Egg. Lias.

Whitby.

Whitby.

Lyme.

do.

do. 
GENERA.

SPECIYS.

ALETHOPTERIS, . heterophylla, (continued.)

Lindleyana,
lonchitidis,

Mantellii,

nervosa,

Sauvcurii,

serra,

Serlii,

urophylla,

vulgatior,

A NABATHRA, ....puleherrima, ANNULARIA, .... fertilis,

longifolia,

ANTHOLITHES, .. anomalus,

Pitcairnia,

APHLEBIA, ...... adnaseens,

ARTISA, . . . . . . approximata,

ristans,

transversa,

ASPIDIARIA, ..... anglica, confluens, cristata, quadrangularis,

undulata.
LOCALITY.

Felling. Coalbrook Dale. Manmebach.

knowlbury.

Newcastle. Coillorook D

Saarbruck. Silesia.

Bideford.

Neweastle. Pontnewrd. Silesia.

Bensham. Coalbrook

Dale. Silesia. Belgium.

Ringley. Belgium. Saarbruck.

Whitehaven. Silesia.

Bath. Dunkerton. St.

Etienne. Devon.

Merthyr Tydvil. Silesia.

Bohemia, Silesia. Devon. Allenbank, Berwickshire.

Bath. St. Etienne. Wilkesbarre.

Bath. Silesia. Alais.

Coalbrook Dale.

Newcastle. Warlic.

Neweastle.

Bolton. Newcastle. So. merset. Coallurook Dale. Ediuburgli.

Seabrook, Yorkshire.

Radnitz. Waldenburg.

Paulton, Somcrset.

England. France. Silcsia

Wardie. Yorksh. Cicrmany

Bierley. Jarrow, Knowl

bury. Germany.

Iarrow, Bolemia 
GENERA.

ASTEROPHYILITES, comosus, foliosus,

galioides,

jubatus, rigidus,

BECHERA, charxformis, graridis,

BORNIA, ...... equisetiformis,

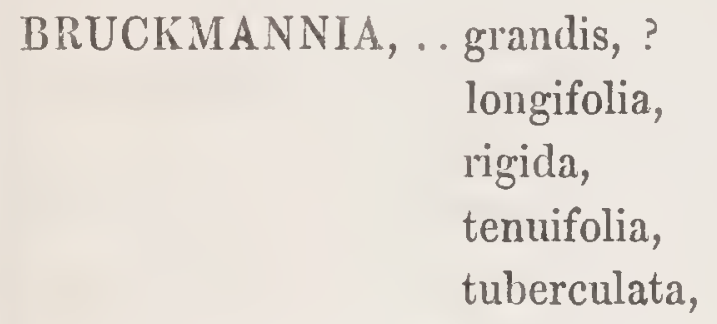

CALAMITES, .... arenaceus,

approximatus.

cannæformis,

Cistii, decoratus,

dubius,

inæqualis, Lindleyi, nodosus,
LOCALITY.

Coalbrook Dale.

Newcastle. Culm series of Deronshire.

Barnsley.

Jarrow. Coalbrook Dale.

Jarrow. Newcastle.

Coalbrook Dalc.

Newcastle. Coalbrook D.

St. Munster. Wardie.

Blackwood, Monmouths.

Mannebach, Germany.

Newcastle.

Newcastle. St. Munster.

Coalbrook Dale.

Newcastle. Silesia. ditto. Coalbrook D. Stuttgardt. Coalbrook Dale. Devon.

Camerton. Coalbrook D. Wentworth, Yorkshire. Kilkenny. Liège.

St. Etienne.

Yorksh. Wigan. Coalbrook

Dale. Mannebach.

Radnitz.

Clee Hill.

Wigan. Lowmoor. Leabrook, Yorksh. Ardwick, near Manchester.

Leabrook, Yorkshire. Zanesville, Ohio.

Sheffield.

Edinburgh.

Newcastle. Coalbrook D. France. 
GENERA.

CALAMITES, (continued)
SI'ECIIES.

ornatus.

pachyderma,

ramosus,

Steinhnueri,

Suckowii,

undulatus,

varians,

verticillatus,

unnamed,

CARDIOCARPON, .. acutum, CARPOLITHES, .. alatus,

Helicteroides, marginatus, sulcatus,

Zamioirles,

CAULOPTERIS, .. gracilis,

Phillipsii, primeva,

(HONDRITES, .... Prestrici, CREPIDOPTERIS, marginat a, CYCLOCLADIA, .. major, CYCLOFPFRIS, .. dilatata, tlabellatis, oblata,

obliqua,

orlicularis,
L.OCA LITY

Jorkshire.

Irelaud. St. Ftienne.

Leal)rook, Yorksh. Ardwick. Mannebaeh. Wet tiu, Ciernany.

Wigan. Yorksh. Mannelach. Wettin. Germ. Newcastle. Wigan. France. Germany. Ameriea.

Wigan. Lowmoor. Boliemia. Devon.

Neweastle.

Pontefract, Yorksh. Waldenburg.

Neweastle.

Neweastle, Se. Burdie II. Jarrow.

Coalbrook Dale.

Leabrook, Iorkshirr.

Wardic, N. B.

Coalhrook Dale.

Madely.

Camerton, Sumersort.

Rialstoch, Bath.

Coalbrook Dale.

Neweastle, de. Mlais.

Newcastle.

Felling.

Wardie. Berghanumen.

Near Bolton-le-Moor.

Coallironk Dille.

Warlie. Yorkshire. (oallirook Dale.

Coallor. I). lingland. lit lerแm. Bohemia. Silmia. 
GLNERA.

SPECIES.

LOCALITY.

CYCLOPTERIS, ... reniformis, Wardie. Dep. d. Var.

(continued.) semiflabelliformis, Coalbrook Dale. trichomanoides, Wardie. St. Etienne.

CYPERITES, ..... bicarinata,

ENDOGENITES, .. striata, EQUISETITES, .... dulius, FAVULARIA, .... nodosa, tessellata,

FI.ABELLARIA, . . . Borassifolia,

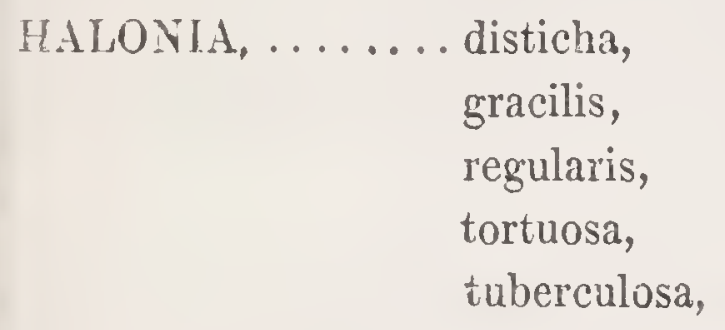

Leebotwood. Shrewsbury. Burdie House. Devon.

Coalbrook Dale.

Wigan, Lancashire.

Flintmarsh, N. Wales.

Denbighsh. Newcastle.

Coalbrook Dale. Westphalia. Alais.

Whitehaven. Coalbrook.

Dale. Jarrow.

Coalbrook Dale.

Low Moor, Yorkshire.

Halliwell, near Bolton.

South Shields. Coalb. D.

Coalbrook Dale.

Newcastle. ditto. ditto.

Park End, For. of Dean. Elsecar, Yorksh.

Elsecar.

Ketley, Shropsh.

Felling. Newcastle.

Saarbruck.

Jarrow. Newcastle. Coalbrook Dale.

Newcastle. Coalbrook D.

Coalbrook Dale.

Ergland. Bohemia.

Newcastle. Coalbrook D.

Newcastle. 
(IFNERA.

SPECILS.

LEPIDODENDRON, elegans, (continued.)

emarginatum,
exsculptum,
graeile,
Hareourtii,

longifolium, obovatum, oocephalum, plumarium, selaginoides, Serlii, Sternbergii,

transversum, Underwoodii,

LEPIDOPHYLLUM, intermedium,

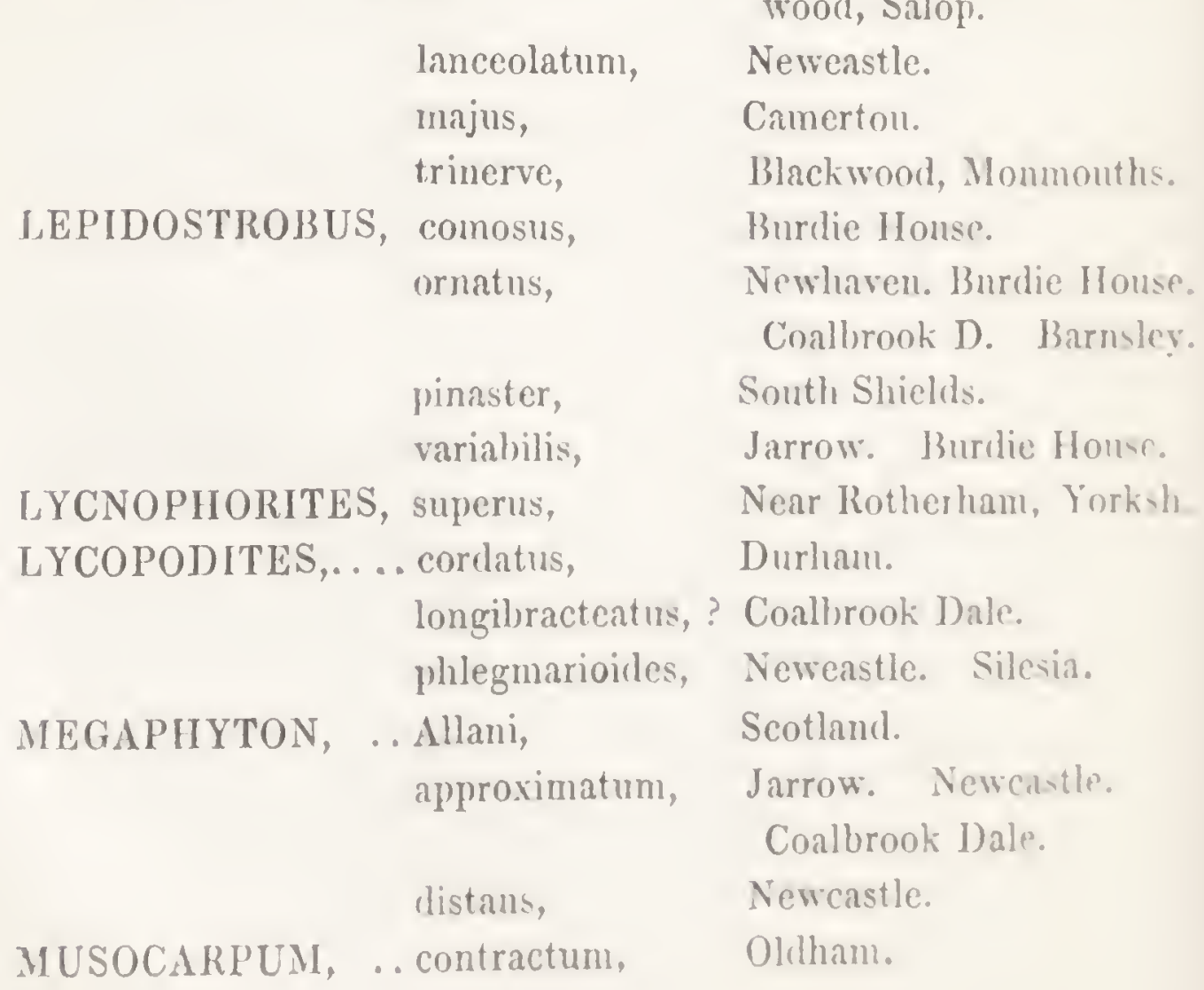

Felling. Wardie. Coalbrook Dale. Bohemia. Yorkshire. England. Neweastle. Coalbrook !). Rothbury. Northumberl. Coallorook Dale. Newcastle. Silesia. Coalbrook Dale. Jarrow. Jarrow.

Bolton. Pembrokeshire. Paulton.

Neweastle. Burdie House. Ardwiek. Bohemia.

Glasgow.

Anglesea .

Burdie Honse. Leehotwood, Salop.

Neweastle. Camertoul.

Blackwood, Monmouths. trie Honse.

Coalbrook D. Barmsler. South Shields.

Jarrow. Burdie Houser.

Near Rotherham, Yorksh nlan. 
GENERA.

SPECIES.

MYRIOPHYLLITES, gracilis, NEUROPTERIS, .. acuminata,

acutifolia,

augustifolia,

attenuata, cordata,

flexuosa,

gigantea,

Grangeri, heterophylla,

ingens, ?

Lindelyana, Loshii,

macrophylla.

Martini,

oblongata, repanda, rotundifolia, Scheuchzeri,

Soretii,

tenuifolia,

thymifolia,
LOCALITY.

Elsecar. Felling.

Felling. Schmalkalden.

Dickenberg.

Bath. Bohemia. Wiln kesbarre

Camerton. Wilkesbarre. Radnitz.

Newcastle.

Leebotwood. Devon.

Alais. St Etienne.

Waldenburg.

Camerton, \&c. France.

Silesia. La Roche. Macot. Devon.

Newcastle, \&c. Saarbruck.

Silesia. Savoy. Deron.

Silverdale mines, Stafford.

Newcastle. Charleroi.

Saarbruck. Devon.

Coalbrook Dale.

Felling.

Newcastle. Lowmoor.

Wilkesbarre. Silesia.

Liège.

Dunkerton, Somerset.

Chesterfield. Alfreton.

Paulton. Temsloury.

Jarrow.

Northumberland.

England. Wilkesbarre.

Osnabruck.

Newcastle. Coalbrook

Dale. Tarentaise.

Newcastle. Saarbruck.

Silesia. Petit-cocur.

Felling. 
GEVIRA.

SPICIES.

NigGGERATHIA, .. flabellata, foliosa,

ODONTOPTERIS, Britamiea, Lindleyana, obtusa, Selllotheimii,

O'TOPTERIS, ..... dubia, ?

PALMACITES, .... astrocariiformis, PECOPTERIS, .... abbreviata, adiantoides, arborcseens,

nignita,

Jirongniartiana, Bueklandi, cremulata, cristata, cyathea, dentata, heterophylla, lacinata, Miltoni,

murieata,

nbliqua, orcoptcridis.

Pluckenctii, plumosa,

pteroides, reparida,
LOCALITY.

Neweastle.

Ardwick. Near Manehester. Bohemia.

Yorkshire. Saxony.

Leebotwood. Silesia.

Coalbrook Dale.

N. Staffordshire.

huowlbury.

Coalbrook Dale.

Radstock. Coalbrook D.

Jarrow. Coalbrook Dale.

Camerton. Bath. France.

Mannebach. Petit Cocur.

St. Itieme. Saarbruek.

U.'States.

Newcastlc.

Camerton.

England. Saarbruck.

England. Saarbruck.

England.

Dunkerton.

Felling. Coalbrook Dale.

Jarrow.

Elscear, Yorkshire. Alais. Saarbruck. Silesia.

Nerreastle. Coalbrook D.

Bohcmia. Silesia. Bideford.

OAdham. Alais.

Wellatch, Shropshire.

Alais. Bohemia. Silesia. Staffordshire.

Oldham. Ashton. Elsecar. Silesia. Saroy. Camerton. darrow. Newcastle. 
GENERA.

SPECIES.

LOCALITY.

PECOPTERIS, (con.) villosa,

PICEA, .........Withami,

PINITES, ........ ambiguus,

anthracina,

Bradlingi,

carbonaceus, medullaris,

Withami,

PINNULARIA, . . . capillacea, PrTUS, ......... antiqua,

primæeva,

POACITES,....... cocoina,

Zexformis.

PROTOPTERIS, .. punctata, RHODEA, ...... delicatula, dissecta, furcata,

SAGENARIA, .... aculeata,

cælata,

Lindleyana, ophiura, Rhodiana,

rimosa,

SELAGINITES, ..patens, SIGILLARIA, .... affinis, alternans, catenulata, contracta,
Camerton.

Durham.

High Heyworth, near Gateshead.

Newcastle.

Wideopen Quarry, near Newcastle.

Allenbank, Berwickshire.

Craigleith.

Craigleith.

Leebotwood. Shrewsb.

Lennel Braes, Tweed Mill, Berwickshire.

Tweed Mill.

Lancash. Wardie. Coalbrook Dale. Devon.

Coal brook Dale.

Whitehaven. Bohemia.

Saarbruck.

Newcastle.

Northumberland. Wardie. Belgium. Saarbruck.

Wardie. Bohemia. Silesia. Wilkesbarre.

Yorkshire.

Jarrow.

Newcastle. Charleroi.

Yorksh. Dudley. Valenciennes. Silesia.

Wardie, N.B. Bohemia. Edinburgh.

Newcastle.

Northumberland.

Newcastle.

Merthyr Tydvil. 


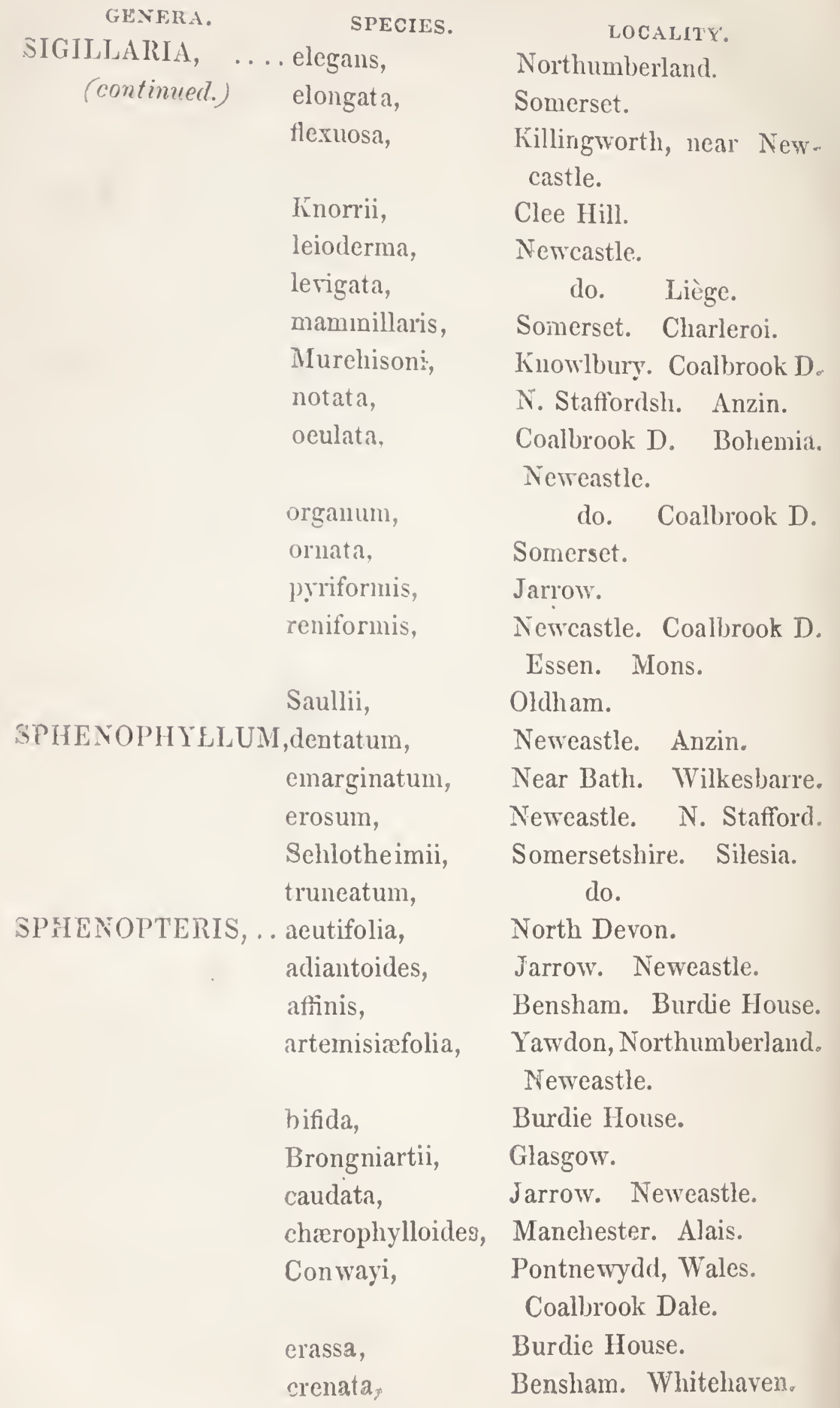


GENERA.

SPHENOPTERIS, . cuneata,

(continued.) cuneolata,

dilatata,

elegans,

excelsa,

gracilis,

Gravenhorstii,

Hibbertii,

Höninghausi,

latifolia,

laxa,

linearis,

macilenta,

multifida,

obovata,

obtusiloba,

polyphylla,

stricta,

tenella,

trifoliata,

STIG MARIA,..... ficoides,

nelocactoides

ninima,

reticulata,

TRIGONOCARPUM, Dawesii,

Nöggerathii,
LOCALITY.

Knowlbury.

Newcastle.

Coalbrook Dale.

Wardie. Silesia.

Ilmaneau.

Newcastle.

Newcastle.

Anglesea. Silesia.

Kirkton, near Bathgate.

Newcastle. Werden.

Radnitz.

Newcastle. Coalbrook D.

Saarbuck. Silesia.

Durham,

Newcastle, \&c. Swina,

Bohemia.

Risca, Monmouthshire.

Coalbrook Dale.

Oldham. Coalbrook

Dale.

Newcastle.

Coalbrook Dale.

Knowlbury.

Yawdon, Northumberland

Yorkshire.

Elsecar, Yorkshire. Valenciennes. Silesia.

Common in the European and American coalfields.

Coalbrook Dale. Saarbruck.

Anglesea. Charleroi.

England.

Peelstone, near Bolton.

Nercastle. Bolton. 
GENERA.

SPECIES.

TRIGONOCARPUM, oblongum,

(continued.) olivæforme, ovatum,

Parkinsonis,

ULODENDRON, .. Allani,

Conybearii,

Lindleyanum,

Lueasii,

majus,

minus,

minutum,

WALCHJA, .... piniformis,

LOCALITY.

Houndhill, Pontefract.

Peelstone Quarry, Bolton.

Ketley, Shropshire.

Leicestershire.

Cragleitl.

Stapleton, near Bristol.

Ketley. Newcastle.

Wakefield.

Swansea, S. Wales.

Nerreastle. Wakefield.

Edinburgh. Yorkshire.

Durham, \&e, Silesia.

Cramlingtoll. Northumb. England. St. Etienne.

IX. Devonian and Silurian.

FUCOIDES, ..... undetermined, Various places.

The following summary of this table will exhibit more clearly the amount of its contribution to our general knowledge of the past.

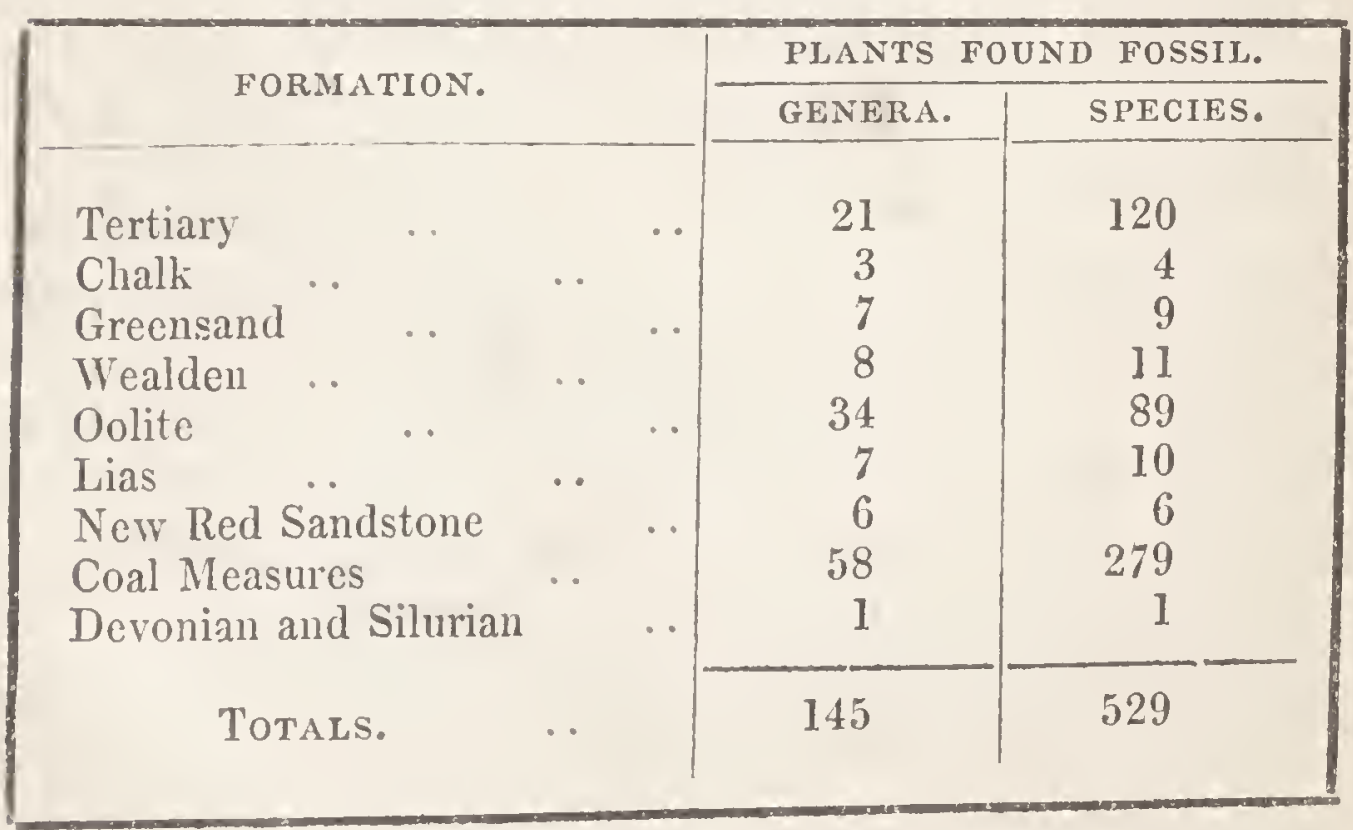


With the aid of the above lists a direct comparison may be made between the accumulations of fossil plants forming coal in the early and middle epochs; and by extending our observation to the Rhine we find in the tertiary brown coal of that locality, a third term in the series. On examining these coal fields thus occurring in the three great periods in geological time, and not far distant from each other in geographical space, we discover that there is no species of plants common to the three formations, or even found in any two of them. Each is distinguished from the other by an invariable difference in species, as well as by the prevalence of distinct tribes of the vegetable kingdom.

Thus where the circumstances have been in each case equal to the production of a profuse vegetation, and even when we find some families of plants, e.g. pines and ferns, persistent throughout more than one epoch, yet there is a total difference of species between the plants found fossil in the coal of the three localities. To this remark an. apparent exception occurs in the plants 
found in the Anthracites of the Savoy Alps. These are said to exhibit true carboniferous fossils, and to be interstratified with lias slate.* The suppositions framed by Mons. Adolphe Brongniart and others, to account for this apparent anomaly, shew their strong conviction of the miversality of the law. The exact geological position of the beds alluded to has not yet been so satisfactorily determined as to require us to make an exception, or to adopt either of the ingenious hypothesis proposed to account for the fact.

It remains that we should generalise some of the views suggested by the foregoing statements.

If we divide the whole of the fossiliferous past into three great periods; I., the early or palæozoic, comprising all fossiliferous strata up to and inclusive of the true coal measures; II., the middle or mesozoic reaching from the upper boundary of the carboniferous system to the upper beds of the chalk ;

* Vide Mr. Bunbury's Memoir Journal of Geological Society, No. 18, and the President's Address in same number. 
III., the later, or cainozoic, including all the tertiary formations up to the superficial gravels, but exclusive of the latter; we have three distinct and separate platforms of life as evidenced by the fact that no species of plant belonging to the one is found in the other; each has separate fossils: there is no identity of species between them, and only a few identical genera. If we add to our consideration the recent beds and diluvial accumulations as a portion of the fourth or present period, this inference may also be extended so as to comprise the whole series of vegetable life.

It may be objected that our researches have not been sufficiently extensive to warrant the formation of so large an induction: but to this it may be replied that we have waited for several years the progress of discovery; much has been done to collect instances, and every fresh contribution of geological facts, harmonizes with the hypothesis long since proposed and now established,-that each of the great geological epochs, is characterised by the remains of distinct kinds of living creatures. 
Another deduction, equally apparent on an inspection of the fossils is, that the same conditions of life existed during their season of vitality as prevail at present.* In all the elements of vegetable existence, the phenomena indicate identical supplies of light, air, and nutriment, and similar physiological and physical arrangements to those which are in active play around us now. Wherever we obtain a fragment of hard wood, we discern in it annular lines of growth; the fallen cones of the coal measures, the thickly strewn floors of tertiary lakes, remind us of the autumnal effects in modern woodlands, when the forest fruits are detached;

"Thick as autumnal leaves that strow the brooks In Vallombrosa."

Some of the consequences of this argument may be stated in the words of Dr. Harris.

* There is rothing, however, to forbid the supposition that during the carboniferous epoch a greater amount of carbonic acid was diffused than cxists at present. Such an effect (within certain limits) whilst prejudicial to air-breathing animals, would be favourable to the rapid growth of vegetation. 
"Did light exist before the plant was created: The humblest herb requires it, seeks after it, and without it perishes. For water, it has the power of absorption. For air, it has the function of respiration; its leaves are in effect its lungs. For the temperature each species possesses a constitutional adaptation which can never be violated with impunity. The first seed that germinated claimed kindred with all the material elements which were in existence when it came. And the bud at this moment bursting, is holding communion with the distant sun, and comes to lay all nature under tribute.*

A third inference is that the variances between the flora of the present, and those of the past, are greater in proportion to the depth of the strata. Thus Sigillaria, Lepidodendron, and many forms to which we have no living resemblances, disappear in the upward progress, and are succeeded by others bearing more of the familiar outline of the present. 
A fourth deduction is that temperature and climate have not been constant, that during the first two geological epochs the climate in the Northern parts of the globe ras very much hotter and more equable than at present.

Fifth. The geographical range of species was far wider during the carboniferous period than at present; whilst during the tertiary formation, local floral provinces began to prevail.

"Thou unrelenting Past!

Strong are the barriers round thy dark domain,

And fetters, sure and fast,

Hold all that cnter thy unbreathing reign.

Far in thy realm withdrawn

Old empires sit in sullenness and gloom,

And glorious ages gone

Lie deep within the shadow of thy womb.

In thy abysses hide

Beauty and excellence unknown-to thee

Earth's wonder and her pride

Are gather'd, as the waters to the sea."-Bryant. 


\section{CHAPTER X.}

CONNECTION WITH OTHER STUDIES.

Union of all Sciences. Relation of Fossil Botany to Geology . Botany. Mining. Chemistry. History. Physical Geography. Connexion with Moral Science. Natural Theology. Argument for design. Illustrations of higher truths. Harmony with Revelation. Temper of mind fostered. Earth a Necropolis.

"And darkness and doubt are now flying awar, No longer I roam in conjecture forlorn, So breaks on the traveller, faint, and astray, The bright and the balmy effulgence of morn, See Truth, Love, and Mercy, in triumph descending, And nature all glowing in Eden's first bloom! On the cold cheek of death, smiles and roses are blending, And beauty immortal awakes from the tomb."-Beattie.

THE chariot of truth like the car of Aurora progresses amidst a sisterhood linked hand in hand. Guido's picture of the morning may well represent the majestic 
progress of knowledge led onwards by the united sciences. Each pressing forward from dawn to daylight, shedding upon its fellows the shining beams as soon as they are received.

Geology owes much of its interest and certainty to the study of organic remains; if it had continued to treat of mineral masses alone, it would have retained a subordinate place amidst the subjects of human inquiry. The phenomena of aggregation, deposit, crystallization, cleavage, metamorphism, and elevation, are topics of severer aspect than the investigation of the " medals of creation."

Botany appeals to her dark sister for the restoration of some links in the chain of present vegetation, apparently lost, but only buried. Plants which have perished from the earth with all their varieties, species, and genera, are highly instructive helps in the study of the existing vegetable kingdom.

The miner finds the fragments of plants useful in guiding his works amidst barren clays and productive coal-beds. The differ- 
ent strata in a colliery may thus be identifier in cases where there is no perceptible variation in mineral structure.*

The chemist discovers in the changes from the living plant into peat, jet, asphalte, bitumen, anthracite, and coal, abundant subjects for his investigation; and he is led to attempt the useful imitation of processes so beneficial to man, as those which are carried on in the great subterranean laboratory of the earth.

The historian, in these ancient inscriptions finds the chronology of events otherwise beyond his province, and is enabled to give

* Mr. Mammatt thus relates an occurrence in the history of the Ashby collieries. "During the workings, great difficulty was experienced in passing faults, in finding the coal again, and in driving adits the shortest way to it. Here it was, that the very important doctrine of Mr. William Smith, came to be of the greatest practical use. By observing the particular fossil plants in the several strata, the manager was enabled to trace the height or deptl to which the dislocated beds had passed. By this method, not only an immense expense was saved, but the operations were rendered almost certain. Many of the alternating seams were so nearly alike in structure, colour and density, as to be scarcely distinguish. able; but the fossil plants or impressions, wherever they could be seen and examined carefully, indicated the particular stratum." Mammatt's Geological Facts, 1836. 
a picture of the Pre-Adamite earth, as introductory to the great drama of life.

Physical geography is conversant with the facts and consequences of pristine vegetation; nor can even the vexed questions of political economy be determined without a consideration of the stores which fossil fuel contribute to the wealth of nations and the materials of commerce.

The more fully developed that any physical science becomes, the more plainly do we perceive the tokens of kindred and affinity between it and all others, indicating relationship to a common origin. Like the multifarious languages of the earth, they display to the student abundant proofs of inherent family likeness. "And if you agree with me in these reflections, you will also methinks feel as I do, that in tracing the history of any pursuit, we are not so much indulging a fond curiosity, or following the progress of man's ingenuity, as watching the beautiful courses whereby God hath gradually removed the veil from before some hidden knowledge, first lifting up one corner thereof, then another, till the whole 
is rolled away; and you will with me delight in studying the purposes and applications thereby intended, both towards our humble instruction and his increasing glory."*

Fossil botany has also other uses besides its application to physical and economical science.

There are connexions between all truth; arguments and analogies in the material world which are apt illustrations of the moral: the real is everywhere symbolical of the ideal.

Although its memorials do not reveal to us the history of man's mind, nor betray the secrets of his true condition, yet they exactly harmonize with the knowledge derived from the more direct sources of reason and revelation, as to the great problems of our nature.

In the progress of our inquiry we have been led to remark how every province of Palæontology abound with illustrations of the wisdom, power, and goodness of God, in the occurrence of numberless contri- 
vances, implying design; there is still a higher branch of analogy, namely, correspondence with the truths of revealed religion.

In this department of learning our science has a place; we may indicate a few directions in which a reflective mind at work amidst its facts, may pursue the profitable path which unites all secular knowledge to that which is the highest:- "wisdom for a man's self.'

We may instance the illustrations afforded by the fossil arrangement of the earth to those truths of revelation which teach us that man is the subject of divine government, and the object of divine purpose. That he is not placed here to be independent of his Maker, but to realize the benefits, and accomplish the objects of a great system, the resources of which were provided for him before his appearance.

When we step across the threshold of a villa at Pompeii, we are amidst the household arrangements of ordinary life, though animation has for centuries fled from the deserted hearths; so on entering the cav- 
erns of the earth, we find them hung around with the furniture of their former inhabitants. As in the one case we trace the handywork of the Roman artist, so do we the workmanship of God in the other; if we yield our admiration to the artistic taste and power exhibited on the walls of the disentombed city, shall we not much more render praise to the infinite skill displayed in the buried organizations of the ancient earth.

But if amidst the ashes of Pompeii we could discover some work which proved that we of this distant place and time were the objects of the care, and forethought, and anxieties, of the good and great of that city;- that the designs which they formed and executed, had especial reference to the supply of our wants, and the gratification of our feelings; - then we should entertain for them higher sentiments than mere admiration; and gratitude would unite with curiosity in impelling our researches amidst the stores of former benevolence.

Such a claim has fossil botany on our regards, for it tells us that man was the object 
of Divine care and provision long before he came to possess his endowment.

The anticipated demand, and the discovered supply in the physical world, has a parallel on a higher level in the foreseen wants and supplies of the spiritual world.

The inference that a purpose is to be accomplished in the moral government of the universe, because we see a plan manifested in all accessible departments of creation, may be extended by the consideration that as in the one we see not yet the end, all things are still working out the vast design; so in the other case, there is a future yet to be attained, and to its probabilities and indications it becomes us devoutly to apply.

The temper of mind which such studies when rightly pursued are calculated to excite, is well expressed by a recent writer.

"The firm believer in revelation examines the result of scientific inquiry, or himself 'opens the inward explication of the form of the world' as food for the reverence he would feel for his Father in Heaven. He is satisfied with the divine word, and, re- 
posing on the promises therein contained, he is grateful and happy.

"How can he better shew his gratitude than by examining the wonders of the omnipotent hand, which, to make a dwelling-place for man, has hung over frowning mountains, and laughing fields, and rejoicing rivers, the ever-shifting and manycoloured canopy of the sky? He may meet with wonders he cannot fathom, and seeming contradictions which he cannot reconcile; but he looks at these as a child regarding some master-piece of his father's skill, his uncertainty melting away into reverence, his perplexity swallowed up in admiration. He has a patient confidence that all is right and reconcileable, and that one day he will himself see how. Meanwhile as he walks abroad, in a world which, to his cultivated eye, is teeming with wonders from the starry host above him, in their exquisite and almost tuneful regularity, making music to their Maker's praise, down to the smallest flower and insect on which he treads, pencilled and articulated with the most delicate care-each new develope- 
ment of complicated structure which he witnesses-each marvellously simple law which he unravels-each adaptation, each curious mechanism or strange chemical effect, affords fresh subject for humble adoration, and for genuine gladness of heart. To borrow the idea of the christian poet, all the works of nature are peculiarly his, who can, without presumption, look upward and say with a smile of joy, 'my Father made them all.'" *

We emerge from the ancient forests into which our subject has led us, with a fresh impression of the familiar truth, that this world is one vast city of the dead. All around us is dying, all beneath us dead. "And they died," is the universal termination of all earthly histories.

Earth was once the home of all the organic forms of which it is now the sepulchre, but it will not be alike their resting place for ever. Man, though like the fern-leaf in his place of life, death, and burial, has however the grand distinction that he will live again.

* North British Review, No. 8, 378. 
The tribes of lower animated nature have had their final developement and display, but no one human creature has ever been lost from the roll of life, or ever will be. The fossil has become reunited with its matrix, but man,- - though all has been thus elaborated and provided for him, - is on this lower world only a guest and not a dweller.

\footnotetext{
"The soul's high price

Is writ in all the conduct of the skies.

The soul's high price is the creation's key,

Unlocks its mysteries, and naked lays

The genuine cause of every deed divine;

That, is the chain of ages, which maintains

Their obvious correspondence, and unites

Most distant periods in one blest design." - Young.
} 


\section{Supplementary Note.}

Sinee the previous pages were written Sir Roderiek Impey Murchison has published in the Quarterly Journal of the Geological Soeiety, No. 19, his Memoir on the Strueture of the Alps. The identification of a rast bed of lower tertiary which covers much of the mighty mountain ehain, and extends southward and eastward through Egypt and. Syria into Central Asia and India, is one fruit of the extensive researches reeorded in this eommunieation. Henceforth the eocene tertiary will vie in extent with the older formations. Sir Roderick grapples with the mueh agitated question (referred to ante p. 206) of the plants of earboniferous speeies being assoeiated with belemnites of liassic species. He eoneludes a full statement of the evidence by expressing his eonviction that the physical faet. is well established: after observing on the fossils lie adds, "If the previous statement of the geologieal rehations at Petit Cœur be, as I thirk, aecurate, i.e. if the plants and belemnites really lie in the same deposit, as was also coneluded by the geologists of the Freneh Soeiety, who met at Chambery, the anomaly is great, and involves us in considerable natural-history difficulties. But are these difficulties insurmountable, and ought geologists to shrink from endeavouring to reconcile them because they interfere with the general distribution of fossil plants? Excluding for the present all theory, let me say that I eannot admit the presence of certain species of fossil plants to be as decisive of the age of a deposit as that of the remains of any well-known animal. Thus, the Calamites arenarius cited by Brogniart as pertaining to the old eoal, is found both in the Permian system and in the Bunter sandstein and Keuper, or throughout the Trias, a system in whieh no one palæozoic animal has been deteeted. Again, the Equisetum columnare, whieh so abounds in the Brora (oolite) eoal, and is most abundant on the Yorkshire eoast beneath the Kelloway rock, is one of the most eommon of the trias plants of Germany. And yet as a whole, both the fauma and flora of the middle oolite and trias are ntterly dissinilar." 
In the same number of the Journal occurs a notice of Professor Broun's Index, Palæontologicus or Review of all known Fossil Organisms, which contains a more numerous list of fossil plants than has hitherto been published.

It is as follows :-

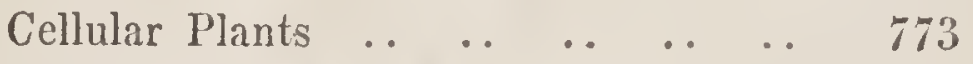

$$
\begin{aligned}
& \text { Vascular Plants- }
\end{aligned}
$$

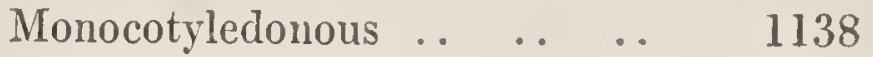

$$
\begin{aligned}
& \text { Dicotyledonous .. } \quad . \quad \ldots \quad \ldots \quad 725 \\
& \text { Undetermined Forms } \quad \text {. } \quad \text {. } \quad 34 \\
& \text { Total _. .. } \quad \ldots \quad \ldots \overline{2670}
\end{aligned}
$$

It is probable that several of these are duplicates, but on the other hand additions by discovery are being constantly made to the number.

T. W. MADDOX, PRINTER, LAUNCESTON. 




\section{QE905.P3}

Pattison, S.R./Chapters on fossil botany || 
